UNIVERSIDADE DE SÃO PAULO

FACULDADE DE ECONOMIA, ADMINISTRAÇÃO E CONTABILIDADE DEPARTAMENTO DE ADMINISTRAÇÃO PROGRAMA DE PÓS-GRADUAÇÃO EM ADMINISTRAÇÃO

A APLICAÇÃO DE UM MODELO DE CONSTRUÇÃO DE CENÁRIOS NO SETOR PRODUTIVO DE ETANOL: UM ESTUDO SOBRE O ETANOL DE SEGUNDA GERAÇÃO

Ricardo Raele

Orientador: Prof. Dr. Adalberto Américo Fischmann

SÃO PAULO

2010 
Prof. Dr. João Grandino Rodas

Reitora da Universidade de São Paulo

Prof. Dr. Carlos Roberto Azzoni

Diretor da Faculdade de Economia, Administração e Contabilidade

Prof. Adalberto Américo Fischmann

Chefe do Departamento de Administração

Prof. Dr. Lindolfo Galvão de Albuquerque

Coordenador do Programa de Pós-Graduação em Administração 


\section{A APLICAÇÃO DE UM MODELO DE CONSTRUÇÃO DE CENÁRIOS NO SETOR PRODUTIVO DE ETANOL: UM ESTUDO SOBRE O ETANOL DE SEGUNDA GERAÇÃO}

Dissertação apresentada ao

Departamento de Administração da

Faculdade de Economia, Administração

e Contabilidade da Universidade de São Paulo, como requisito para a obtenção do título de Mestre em Administração.

Orientador: Prof. Dr. Adalberto Américo Fischmann

SÃO PAULO 


\section{FICHA CATALOGRÁFICA}

Elaborada pela Seção de Processamento Técnico do SBD/FEA/USP

\section{Raele, Ricardo}

A aplicação de um modelo de construção de cenários no setor produtivo de etanol : um estudo sobre o etanol de segunda geração / Ricardo Raele. -- São Paulo, 2010.

$140 \mathrm{p}$.

Dissertação (Mestrado) - Universidade de São Paulo, 2010. Orientador : Adalberto Américo Fischmann.

1. Administração estratégica (Modelos) 2. Etanol I. Universidade de São Paulo. Faculdade de Economia, Administração e Contabilidade. II. Título.

$$
\text { CDD - } 658.4012
$$


DEDICATÓRIA

A todos que acreditam que o futuro pode ser melhor que o passado e fazem dessa crença a raiz de suas esperanças. 


\section{AGRADECIMENTOS}

Gostaria de agradecer a todas as pessoas com quem convivi durante o tempo em que esse trabalho foi desenvolvido. Seria impossível retribuir tudo que me foi ensinado durante esse tempo. A todos de minha família que me deram suporte, minha mãe Silvia, meu irmão Marcus e minha avó Iselda.

Ao Prof. Dr. Adalberto A. Fischmann meu mais sincero agradecimento por ter acreditado em minha capacidade e ter me escolhido como seu orientando.

Ao Prof. Dr. Martinho Almeida dirijo minha gratidão por ter me recebido no seu grupo de estudos durante o ano anterior ao meu ingresso no mestrado, tempo em que me preparei para essa empreitada.

Ao Prof. Dr. João Maurício Gama Boaventura, membro ilustre de minha banca examinadora que contribuiu com tantos pontos importantes sobre esse trabalho e ao Prof. Dr. Silvio Aparecido dos Santos pela ajuda na elaboração do projeto.

Gostaria de agradecer especialmente à Prof. Dra. Silvia Molina pelo apoio incondicional.

Aos colegas Caio Gomes e Daniela Bittencourt pelas valiosas sugestões e revisões.

Aos profissionais que entrevistei e que colaboraram espontaneamente nas diversas etapas realizadas para tornar essa dissertação possível, meu muito obrigado.

Finalmente, aos funcionários da FEA que sempre me ajudaram no dia a dia dos dois últimos anos, meus mais sinceros votos de agradecimento. 


\section{RESUMO}

O mundo está passando por uma transformação profunda no setor energético. Ao que tudo indica estamos rumando para uma economia baseada em energias renováveis e de baixa emissão de carbono. O programa de bionenergia do Estado de São Paulo é o maior programa de bioenergia do mundo. Dentro desse programa produz-se etanol a partir da cana-de-açúcar, precisamente dos açúcares simples da cana-de-açúcar. O etanol produzido a partir dos açúcares simples da planta é denominado etanol de primeira geração. Entretanto, existe uma nova tecnologia para se produzir etanol a partir da celulose da cana-de-açúcar - o etanol de segunda geração - que possibilitará aumentar a eficiência energética do processo e fortalecer a competitividade do setor bioenergético nacional.

O objetivo desse trabalho é prospectar cenários para o futuro do setor produtivo de etanol em São Paulo tendo em vista o etanol de segunda geração como elemento produtivo adjacente à produção atual de primeira geração. Para isso utilizou-se um modelo de construção de cenários que pressupõe uma detalhada consulta a especialistas, qualificação de variáveis quanto à sua importância e incerteza e identificação de variáveis-chaves. Por fim, foram criadas matrizes e roteiros para os cenários a partir das variáveis-chaves identificadas.

Concluiu-se que dos quatro cenários construídos dois são favoráveis, um é desfavorável e um é pouco plausível. A metodologia de geração de variáveis-chaves foi aplicada com sucesso no setor produtivo de etanol. Os cenários criados podem lançar alguma luz possíveis futuros do setor estudado em relação ao etanol de segunda geração. 


\begin{abstract}
Nowadays the world's energy sector is in a process of deep transformation. Apparently the world is going to a renewable energy based matrix, with low carbon emissions. The Sao Paulo's bioenergetical program is the biggest renewable energy program in the world. In addition to that, it is also produced in that program ethanol from sugar cane. The ethanol that is produced in that program is made from the simple sugars of sugar cane. This ethanol is named "first generation ethanol". However, there is a new technology to produce ethanol from sugar cane's cellulose, named "second generation ethanol”. This important new technology could increase the energetic efficiency of process and make the Brazilian's energetic production competitiveness stronger.

The objective of this work was to prospect scenarios for the ethanol's future in Sao Paulo looking at the second generation ethanol. For that it was used a model of scenario construction that presupposed an exhaustive inquire applied to specialists, qualifying trends related to their importance and uncertainty, and identifying the key parameters. At last, extracting the key parameters, matrices were made, and scripts too, both related to these scenarios.
\end{abstract}

The conclusion was that the methodology for scenarios generation was applied with success on the ethanol industry, and those scenarios were able to illuminate with some light under plausible futures about the second generation ethanol. 


\section{LISTA DE FIGURAS}

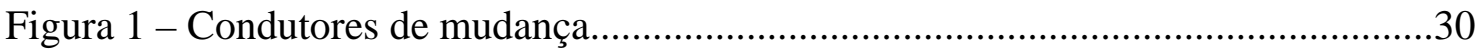

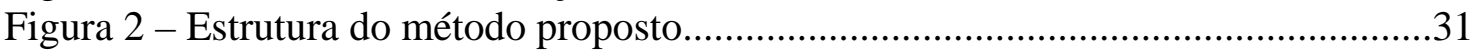

Figura 3 - Matriz de importância e incerteza...................................................................33

Figura 4 - Gráfico de influência e dependência...............................................................34

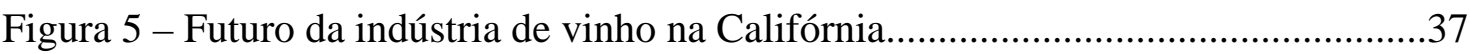

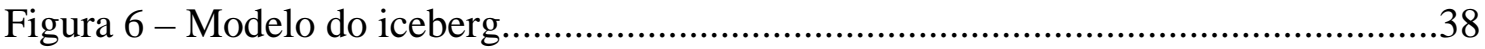

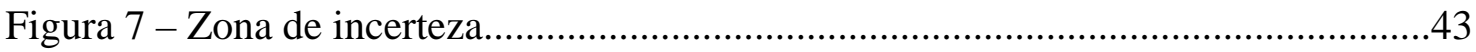

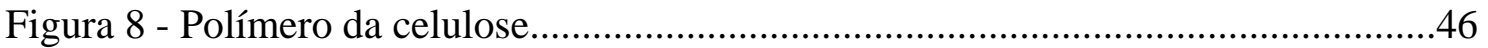

Figura 9 - Modelo conceitual-teórico da pesquisa.........................................................51

Figura 10 - Gráfico de frequência da importância das variáveis.....................................70

Figura 11 - Gráfico de frequência da incerteza das variáveis........................................72

Figura 12 - Gráfico da matriz de importância e incerteza.............................................73

Figura 13 - Matriz de influência e dependência...........................................................82

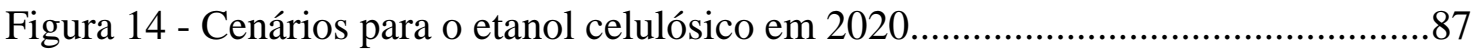

Figura 15 - Valores do etanol pagos ao produtor e preço da gasolina............................95 


\section{LISTA DE TABELAS}

Tabela 1 - Média e desvio padrão das variáveis usadas na segunda fase do estudo.......74

Tabela 2 - Médias e normalização da influência e da dependência das variáveis............80

Tabela 3 - Desvio padrão da influência e dependência das variáveis..............................81 


\section{LISTA DE QUADROS}

Quadro 1 - Tipologia de cenários. .17

Quadro 2 - Comparação dos aspectos mais importantes das três escolas e modelos de cenários. .19

Quadro 3 - Resumo dos principais aspectos tipológicos dos cenários. .22

Quadro 4 - Stakeholders citados por especialistas.........................................................57

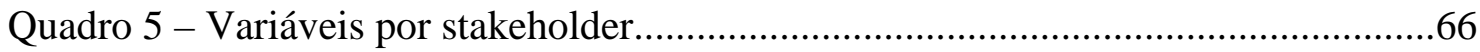

Quadro 6 - Variáveis qualificadas para identificação das variáveis-chaves....................77 Quadro 7 - Classificação das variáveis nos cinco campos da matriz de influência e dependência 


\section{SUMÁRIO}

\section{O PROBLEMA DE PESQUISA}

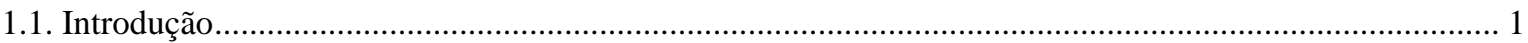

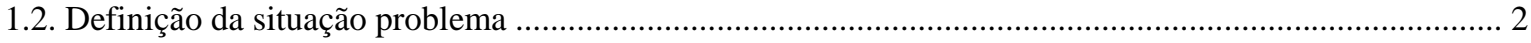

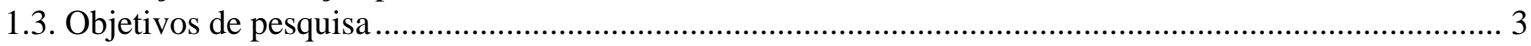

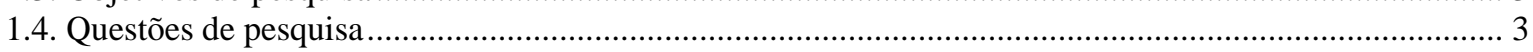

1.5. Definições teóricas e operacionais de pesquisa ...................................................................................... 3

1.6. Pressupostos conceituais ................................................................................................................. 5

\section{FUNDAMENTAÇÃO TEÓRICA}

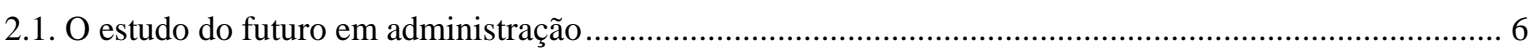

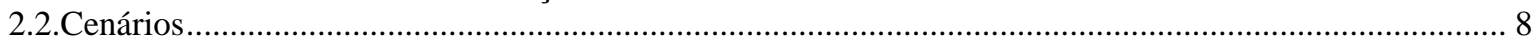

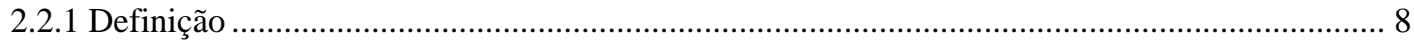

2.2.2 Histórico e desenvolvimento dos cenários .............................................................................. 10

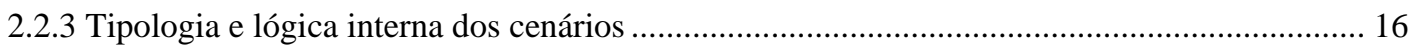

2.2.4 Modelos de construção dos cenários ..................................................................................... 22

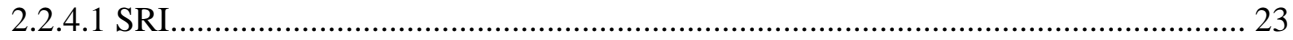

2.2.4.2 Análise Prospectiva ................................................................................................... 24

2.2.4.3 Battelle Memorial Institute............................................................................ 25

2.2.4.4 Compreensive Situation Mapping ………………………………………...... 25

2.2.4.5 Future Mapping ………………………………………………………………. 26

2.2.4.6 Análise de Impactos de Tendências...................................................................... 27

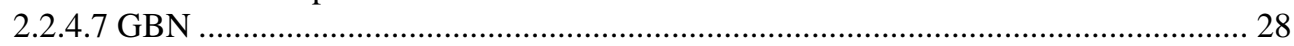

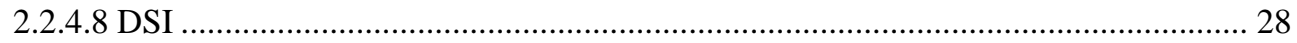

2.2.5 Modelo proposto por Boaventura, Costa e Fischmann ............................................................. 29

2.2.6 A elaboração de cenários e enredos para os cenários ................................................................. 35

2.2.7 Aspectos contemporâneos sobre os modelos de construção de cenários..................................... 38

\section{O ETANOL DE SEGUNDA GERAÇÃO}

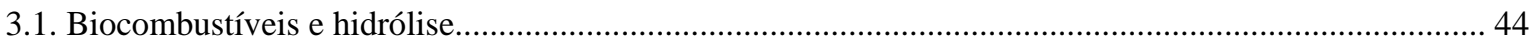

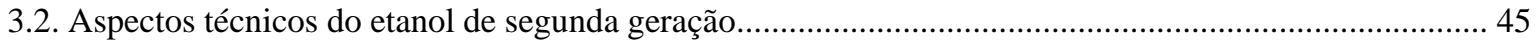

\section{PROCEDIMENTOS METODOLÓGICOS}

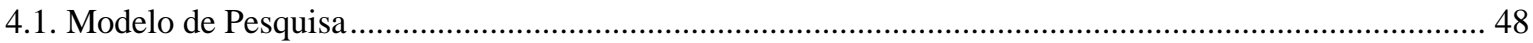

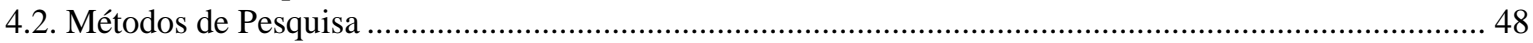

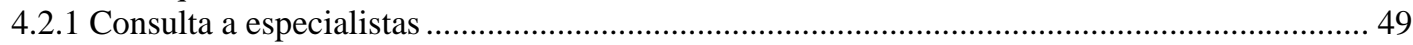

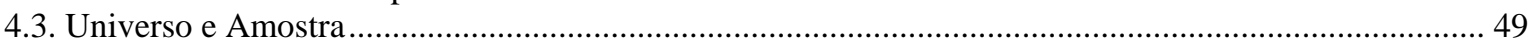

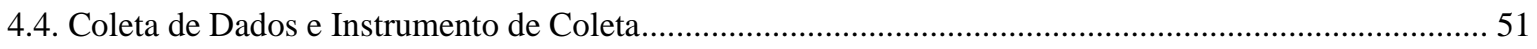

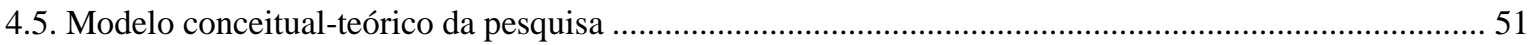

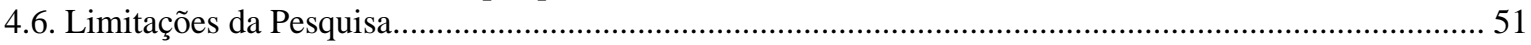

\section{CONSULTA AOS ESPECIALISTAS}

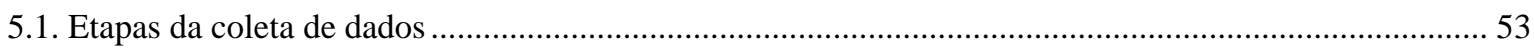

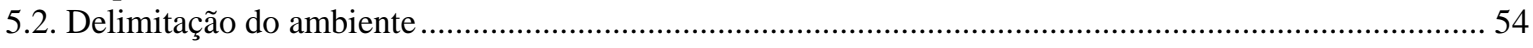

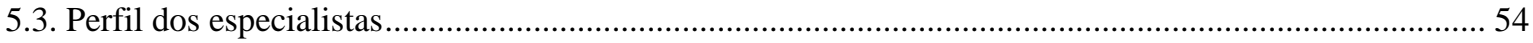

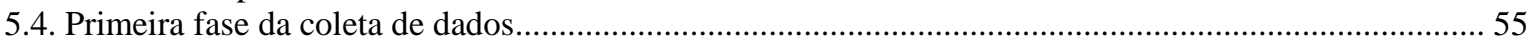

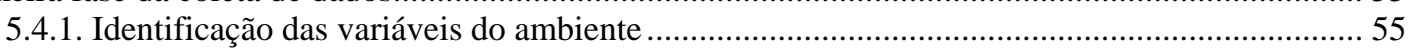

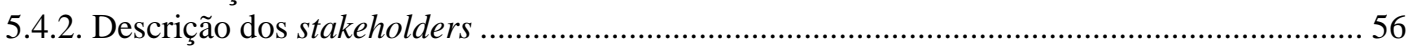

5.4.3. Análise dos stakeholders e variáveis levantadas ...................................................................... 57

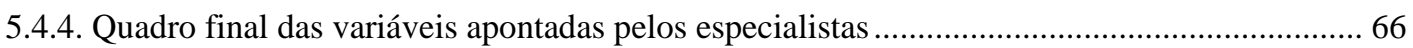

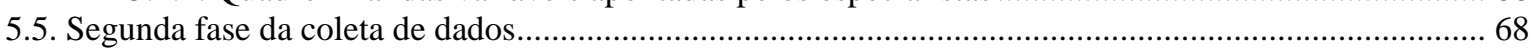

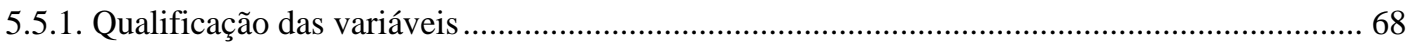

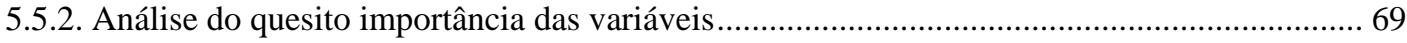

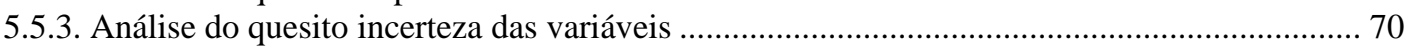

5.5.4. Matriz de importância e incerteza ..................................................................................... 72 
5.5.5. Variáveis selecionadas para terceira etapa do estudo .................................................... 77

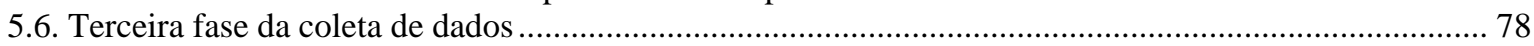

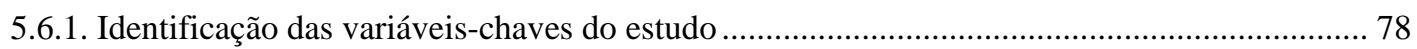

5.6.2. Resultados da influência e dependência das variáveis..................................................... 79

5.6.3. Matriz de influência e dependência ................................................................................... 81

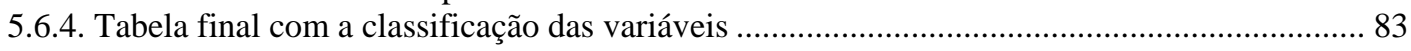

\section{CENÁRIOS}

6.1. Cenários a partir das variáveis-chaves e variáveis dependentes ........................................................ 86

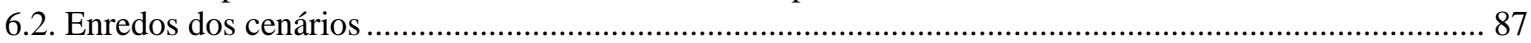

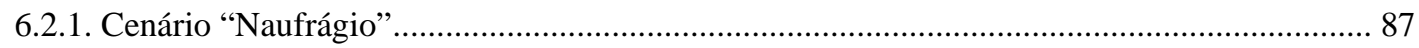

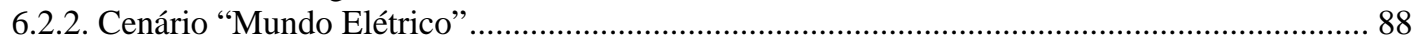

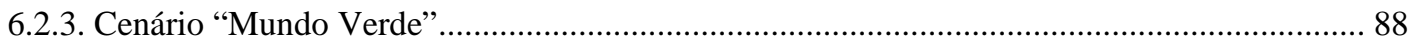

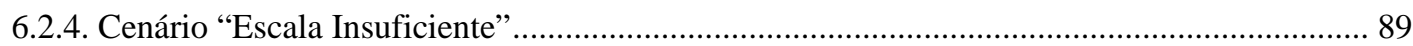

\section{CONCLUSÕES E RECOMENDAÇÕES}

7.1 Conclusões sobre os cenários produzidos 90

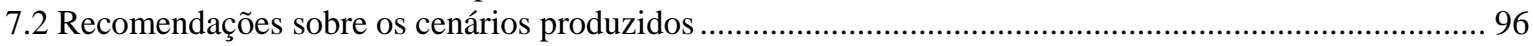

7.3 Conclusões e recomendações sobre a aplicação do modelo de geração de variáveis-chaves ....................97

\section{REFERÊNCIAS}

ANEXO 1 - Lista de usinas de etanol do Estado de São Paulo

ANEXO 2 - Lista dos especialistas consultados

ANEXO 3 - Instrumentos de coleta dos dados

ANEXO 4 - Unificação de vocabulário, eliminação de variáveis supérfluas e de variáveis equivalentes 


\section{O PROBLEMA DE PESQUISA}

\subsection{Introdução}

Imaginar o futuro e antecipar ações sobre eventos hipotéticos é um exercício natural da mente humana. Evidências sobre métodos para investigar o futuro pode ser encontrada na Grécia antiga, especificamente no templo de Delfos - ou ainda em antigas artes divinatórias do extremo oriente. Entretanto, nesses casos, com caráter ocultista - ou seja, longe de ser científico. Era comum que os líderes políticos consultassem tais oráculos a fim de lastrear suas decisões administrativas e militares.

Na idade média houve uma releitura do conhecimento antigo sob a ótica dos pensadores escolásticos. Toda a arte divinatória da antiguidade fora condenada como atitude herética, cabendo apenas à divindade conhecer o futuro. Com o fim do feudalismo e o posterior estabelecimento dos estados nacionais, as atividades militares ganharam importância crucial, fazendo com que se aprimorasse o pensamento estratégico e estudos embrionários na construção de cenários futuros fossem feitos.

Durante a Segunda Guerra Mundial os ocidentais fizeram vasto uso de modelos para imaginar o futuro, incorporando e modernizando técnicas de construção de cenários no suporte à decisão estratégica. A sistematização na construção de cenários e a consolidação de modelos de caráter científico tiveram seu desenvolvimento no ocidente com tais atividades militares.

Com o fim da Segunda Guerra Mundial, a ciência de se construir cenários migrou do campo militar e passou a ser utilizada no universo acadêmico-corporativo como ferramenta de análise mercadológica. Equipes de diversas universidades e empresas de grande porte, baseadas em dados qualitativos e quantitativos, criaram seus próprios modelos de construção de cenários. Um exemplo clássico é o da Shell que projetou perturbações no preço do barril de óleo. Tal visão antecipada sobre o mercado petrolífero interferiu nas decisões de investimento da companhia e conferiu a ela vantagem competitiva no longo prazo. 
Posteriormente os métodos de geração de cenários se difundiram, escolas de estudos prospectivos foram fundadas. Com elas realizaram-se aprimoramentos técnicos e teóricos nas formas de se prospectar o futuro.

O universo acadêmico brasileiro também deu importantes contribuições aos métodos de construção de cenários. Tomando por base estudos metodológicos brasileiros, este trabalho se propõe a construir cenários para o setor produtivo de etanol.

\subsection{Definição da situação problema}

É amplamente aceito que os métodos de construção de cenários mostram-se fundamentais para se pensar sobre o futuro. E a necessidade de pensar o futuro torna-se veemente no mundo de rápidas transformações e imprevisibilidade em que passamos a viver depois da difusão das tecnologias criadas a partir da década de sessenta.

Alguns setores da economia estão sujeitos a transformações profundas e velozes, com inovações repentinas. Nesses setores há uma necessidade ainda mais evidente de se imaginar o futuro, visto que é preciso antecipar-se às transformações. Tal é o caso das energias renováveis, particularmente dos biocombustíveis.

Produzir etanol dos açúcares solúveis da cana-de-açúcar é algo que o Brasil faz há quase quinhentos anos, e essa forma de produzir etanol é hoje chamada de produção do etanol de primeira geração. Entretanto, existe atualmente um esforço importante no desenvolvimento da tecnologia de produção de etanol de segunda geração, que consiste no processo de produzir etanol exclusivamente a partir da celulose (bagaço) - e não dos açúcares solúveis da cana-de-açúcar.

O Brasil é o país mais competitivo no mundo quando se trata da produção de etanol de primeira geração. Se o país manterá sua competitividade quando, e se, o etanol de segunda geração se tornar uma realidade nas usinas é algo a se investigar. A aplicação de um método de construção de cenários para prospectar a influência do desenvolvimento da tecnologia de segunda geração nas usinas produtoras de etanol deve ser vista com especial atenção, devido à necessidade de se prospectar o futuro do setor. 
Considerando a ausência de estudos do futuro sobre o etanol de segunda geração e a necessidade de se testar métodos de construção de cenários para o setor de bioenergia, torna-se evidente a proposição do problema de pesquisa. Como sanar a ausência de estudos sobre o futuro para o etanol de segunda geração através da aplicação de um método de construção de cenários?

\subsection{Objetivos da pesquisa e justificativa}

Atualmente, há um esforço conjunto do setor produtivo e do governo para o desenvolvimento da produção de etanol de segunda geração. A relevância econômica desse desenvolvimento é importante para manutenção da liderança competitiva na produção de etanol que o Brasil detém. Entretanto não foram encontradas na literatura pesquisas sobre o futuro desse desenvolvimento nas principais bases de dados internacionais, catálogos públicos de teses e livros na área. Foram amplamente pesquisados bancos de dados na área de cenários (periódicos, livros e teses em administração e economia), e de energia (periódicos livros e teses em engenharia química e biotecnológica).

O objetivo principal dessa pesquisa é construir cenários sobre o desenvolvimento do etanol de segunda geração no setor produtivo paulista para o horizonte de dez anos.

O objetivo secundário é aplicar um método de geração de variáveis-chaves no setor de produção de etanol.

\subsection{Questões de pesquisa}

Tendo em vista que o etanol de segunda geração tem sido exaustivamente pesquisado no Brasil e que a indústria de etanol de cana-de-açúcar deverá lidar com tais inovações produtivas nos próximos dez anos, surge a questão principal dessa pesquisa:

Quais seriam os cenários em 2020 para o setor produtivo de etanol paulista tendo em vista o desenvolvimento do etanol de segunda geração?

A questão secundária versa sobre o método a ser aplicado: 
Como o método de geração de variáveis-chaves usado na metodologia desse estudo se comportará na tarefa de gerar cenários para setor produtivo de etanol?

\subsection{Definições teóricas e operacionais da pesquisa}

A fim de tornar explícitos os conceitos teóricos e operacionais da pesquisa, no intuito de trazer precisão para as eventuais interpretações contidas nesse estudo, é válido definir os termos fundamentais que escoram esse trabalho.

a) Cenários - Referem-se aos cenários de primeira geração, ou cenários ambientais. Os cenários de primeira geração, por sua vez, definem-se por construir estritamente os desdobramentos de eventos futuros do ambiente, sem a intenção de propor estratégias em sua concepção, conforme Georgantzas \& Acar (1995, pg.29).

b) Método de construção de cenários - Define-se como método de construção de cenário um conjunto de métodos para coletar dados e processá-los, bem como identificar as variáveis-chaves na construção de futuros plausíveis.

c) Variáveis-chaves - Elementos fundamentais no processo de construção de cenários, no qual estão definidas as variáveis que configurarão a estrutura conceitual de um futuro plausível descrito na forma de cenário. Apresentam-se na forma de tendências ou incertezas. As variáveis-chaves são identificadas segundo Godet (1982, pg.299).

[...] [a partir] do confronto das variáveis relativas ao fenômeno que está sendo estudado e as variáveis que descrevem o ambiente, ao se usar uma análise exploratória tão vasta e exaustiva quanto possível [...]

d) Tendências - “[...] são variações no ambiente externo, lentas ou rápidas, entretanto de caráter persistente que podem afetar os negócios ou atividades da instituição, de seus clientes [...] ou da sociedade em geral” (COSTA 2002, pg. 82). 
e) Incertezas - “[...] caracteriza[m] um evento em que as probabilidades não são conhecidas, mas as variáveis sim [...]” (AYRES e AXTELL, 1996, pg.211).

f) Etanol de primeira geração - Etanol produzido a partir da fermentação dos açúcares simples encontrados nos vegetais. Operacionalmente, nessa pesquisa, assume-se que são os açúcares simples e fermentáveis encontrados na seiva da cana-de-açúcar.

g) Etanol de segunda geração - Etanol produzido a partir da celulose por meio de biotecnologias desenvolvidas após a década de sessenta. Operacionalmente nessa pesquisa assume-se que o etanol de segunda geração é aquele produzido a partir da quebra da celulose do bagaço da cana-de-açúcar através do processo de hidrólise enzimática.

h) Hidrólise Enzimática - Reação química que através da ação de enzimas quebra o polissacarídeo da celulose transformando-o em açúcares simples, passíveis de fermentação por microrganismos.

\subsection{Pressupostos conceituais}

O primeiro pressuposto conceitual a ser assumido para essa pesquisa é que o método de geração de variáveis-chaves e a respectiva construção de cenários não se propõem a antever um futuro que virá a ser, mas sim, prospectar futuros plausíveis. Portanto, tratase de um exercício de prospecção e não de previsão.

O segundo pressuposto conceitual a ser assumido é que a geração de variáveis-chaves e a respectiva construção de cenários constituem formulações cujas bases metodológicas são racionais e formalmente definidas por um método. Portanto, pressupõe-se ter a construção de cenários um método reconhecidamente científico, com campo epistemológico definido, conforme descrito em Bell (1989, pg.118). 


\section{2 - FUNDAMENTAÇÃO TEÓRICA}

\subsection{O Estudo do Futuro em Administração}

A idéia de tentar imaginar o futuro caminha junto com a história do pensamento humano. O problema da causalidade é um problema fundamental para ciência. Lembrar do passado, pensar o presente e imaginar o futuro é um processo cognitivo comum entre os seres humanos. Maximiano (2002, pg.75) resgata um fato histórico que serve para ilustrar tal idéia:

\footnotetext{
"Por volta de 3100 a.C., o Egito foi unificado, dando origem a um reino que chegaria até o início da era cristã. [...] A regularidade das inundações do Nilo teve grande influência sobre os egípcios, levando-os, provavelmente, a desenvolver uma mentalidade orientada para o planejamento de longo prazo."
}

Para tratar da relação entre a idéia de pensar o futuro e a teoria da administração em tempos menos remotos é possível lembrar-se dos processos administrativos mais fundamentais, cuja origem remete ao pensamento de Fayol (2006): Administrar envolve, necessariamente, (1) planejar, (2) organizar, (3) executar e (4) controlar. A relação do futuro com a administração pode ser vista logo no primeiro conceito: planejar, que envolve necessariamente pensar no por vir, imaginá-lo, investigá-lo, mas, principalmente, racionalizá-lo:

Administrar envolve: "definir o futuro da empresa, principalmente, suas metas, como serão alcançadas e quais são seus propósitos e seus objetivos", ou ainda, "[...] é a ferramenta que as pessoas e as organizações usam para administrar suas relações com o futuro. É uma aplicação específica do processo decisório.” (ARAÚJO, PG.169, 2004)

O pensar sobre o futuro está ligado à etapa de planejamento na administração. Dentro da etapa de planejamento, encontra-se a necessidade de construção hipotética de futuros plausíveis - não de previsão - visto que ao planejar imagina-se o que poderá acontecer e mais do que isso - basear as decisões presentes tendo em vista o por vir.

No tempo presente, administrar envolve, segundo Araújo (Ibdem., pg. 169), “[...] definir o futuro da empresa, principalmente, suas metas, como serão alcançadas e quais são seus propósitos e seus objetivos [...]" Ou ainda, "[...] é a ferramenta que as pessoas e as 
organizações usam para administrar suas relações com o futuro. É uma aplicação específica do processo decisório.” (MAXIMIANO, Op. cit., pg. 105)

Nesse contexto, Porter enfatiza que as prospecções e o emprego de cenários são uma técnica valiosa para as empresas. "[...] cenários são uma ferramenta poderosa para lidar com a incerteza ao se fazer escolhas estratégicas [...]" (PORTER, 1985 pg.447), [trad. do autor].

Vale dizer que existem dois tipos de cenários usados no campo da administração. Os cenários de primeira geração (cenários ambientais) e os cenários de segunda geração (cenários estratégicos). Pode-se entender que o primeiro tipo limita-se a prospectar o futuro. O segundo propõe uma agenda de ações estratégicas tendo em vista esses futuros imaginados.

Há, ainda, diferentes maneiras de se pensar o futuro, inclusive no que tange a concepção de viabilidade em se prevê-lo. Enquanto algumas técnicas se propõem a prever o futuro valendo-se principalmente de modelagens matemáticas e projeções, outras procuram construir futuros plausíveis sem que haja previsão envolvida.

Esse estudo se propõe a prospectar futuros plausíveis através de entrevistas com especialistas. O objetivo dessas entrevistas está em identificar as variáveis-chaves que interferem no futuro do ambiente em análise, construindo-se enredos a partir delas.

De modo geral, as críticas metodológicas e epistemológicas feitas aos estudos do futuro são muito semelhantes às críticas feitas para as ciências sociais que de alguma maneira procuram relações causais entre premissas e conclusões em ciência não exatas. Godet (1993) aponta que entre as principais limitações dos estudos do futuro, estão a imperfeição dos modelos matemáticos projetivos e o simples fato de o futuro poder não ser condicionado pelo passado e pelo presente, o que colocaria em xeque os esforços de pensá-lo. Embora Van Vught (1987), Georgantzas e Acar (1995) e Ayres e Axtell (1996) concordem com Godet em afirmar que o passado pode não determinar o futuro, isso não significa que ele necessariamente não o influencie de alguma forma. Mais do que isso, o fato de não ser possível prever o futuro não invalida a necessidade humana de pensá-lo. 
As técnicas de previsão e prospecção do futuro têm se mostrado válidas para as ciências sociais aplicadas. Tal validade se reafirma, inclusive, pelo fato de ser uma iniciativa de se estudar socialmente o futuro, visto que a historiografia, a sociologia e a antropologia se voltam principalmente para fatos passados. Há uma lacuna de estudos do futuro nas ciências humanas - e essa lacuna é preenchida pelos estudos prospectivos da economia e da administração.

\subsection{Cenários}

Os métodos de construção de cenários, como já fora dito, não têm a pretensão de prever o futuro, mas de pensá-lo. Por isso, embora sejam menos ambiciosos que os métodos de previsão, possuem um arcabouço epistemológico mais robusto - visto que não se propõem a algo tão ambicioso. Além disso, os métodos de construção de cenários foram testados empiricamente de maneira sistemática por empresas, organizações e governos, desenvolvendo-se portanto durante os últimos anos. Segue-se com a definição de cenário e os métodos mais representativos desse campo de estudo.

\subsubsection{Definição}

De acordo com o Dicionário Etimológico Internacional (www.myetmology.com) a origem da palavra "cenário" remonta há longa data. A raiz da palavra "cenário" é latina, ou seja, vem do latim e é comum tanto ao português como ao inglês. Cenário vem de "scenarium", que significa:

\section{Lugar onde ocorre a cena;}

2. Limites do palco; e,

3. Enredo.

O termo foi inicialmente adotado pelo italiano sob a forma de "scenario" e, posteriormente, pelo português e inglês.

A palavra "cenário", na língua portuguesa, segundo o dicionário Houaiss (2007), possui seis significados. São eles: 
1 Rubrica: cinema, teatro, televisão. Conjunto de elementos visuais (tais como telões, móveis, objetos, adereços e efeitos de luz) que compõem o espaço onde se apresenta um espetáculo teatral, cinematográfico, televisivo etc.; cena, dispositivo cênico;

2 Rubrica: cinema, literatura, radiofonia, teatro, televisão: Lugar em que decorre a ação ou parte da ação de peça, filme, telenovela, radionovela, romance etc.; cena;

3 Derivação: por metonímia: A arte dramática; teatro;

4 Rubrica: cinema. m.q. roteiro;

5 Derivação: por extensão de sentido: Lugar em que se desenrola algum fato; palco. Ex.: esta praça já foi c. de um massacre;

6 Derivação: por extensão de sentido: Conjunto do que se descortina à vista; panorama, paisagem, cena. Ex.: o c. da Marambaia é uma beleza.

Já, Ferreira (1995), no Dicionário Aurélio Básico da Língua Portuguesa, em relação ao termo "cenário", aponta:

1. Conjunto dos diversos materiais e efeitos cênicos (telões, bambolinas, bastidores, móveis, luzes, formas e cores), que serve para criar realidade visual ou atmosfera dos locais onde decorre a ação dramática; cena.

2. Lugar onde ocorre algum fato, ou onde decorre a ação, ou parte da ação, de uma peça, romance, filme, etc.

3. Panorama, paisagem.

De fato, “cenário” é uma palavra portuguesa, entretanto, por possuir uma raiz no latim arcaico, seus significados sofreram diversas nuances no tronco lingüístico. Por isso, os significados da palavra "cenário" sofreram nuances de significado entre os idiomas que a adotaram. Foi no inglês que a palavra ganhou seu significado pertinente ao campo da administração, pois scenario, em inglês, segundo o dicionário Collins Language Online Dictionary (www.collinslanguage.com), significa:

1. Summary of the plot of a play or film "Resumo do enredo de uma peça ou filme" [Trad. do autor]).

2. Imagined sequence of future events "Seqüência imaginada de eventos futuros" [Trad. do autor]). 
O significado preciso da palavra "cenário" empregado no campo da administração e, conseqüentemente nessa pesquisa, é o significado coerente com o significado absorvido pelo inglês "Imagined sequence of future events", visto que não se incorporou, ainda, esse significado na língua portuguesa.

\subsubsection{Histórico e desenvolvimento dos cenários}

A tarefa de construir uma seqüência de eventos futuros sobre a realidade é um exercício milenar e seus registros têm origem no pensamento estratégico e militar. Um dos registros mais antigos encontra-se na China, onde a criação de cenários de batalha foi tratada - de maneira ainda não científica - por Sunzi, explicitada no primeiro capítulo da obra “Arte da Guerra”.

Segundo o Dicionário Oxford Chinese-English, a tradução de " 兵 法 " por "A Arte da Guerra" apresenta diferentes possibilidades interpretativas. O primeiro ideograma é o desenho de um machado sobre a madeira, " 兵", e representa a guerra, a luta, as armas. O segundo ideograma, " 法 ", é composto de duas partes. A parte esquerda do ideograma, formada por três traços, representa pictoricamente um rio correndo, ou seja, a água em movimento. A parte direita significa "ir". Quando completo, o ideograma transmite a idéia de: "como a água segue". Na tradição cultural chinesa a água inexoravelmente segue o caminho correto para chegar ao mar, daí em chinês o ideograma completo significar "lei" ou "método", mais precisamente "a maneira correta de seguir".

A tradução literal da obra de Sunzi supra mencionada pode ser "O Método da Guerra", ou ainda "A Doutrina da Guerra". Ocorre que na China antiga não houve a departamentalização e a especialização das áreas do conhecimento como no ocidente, fazendo com que a idéia de arte não se separasse da idéia de método ou mesmo de doutrina. Por isso, método, arte e doutrina, em mandarim, são conceitos muito mais próximos que nas línguas indo-européias. 
A primeira metodologia descrita nesse livro chinês é justamente o método da análise ambiental, que propõe, de forma primordial e indireta, um método de construção de cenários de batalha. Assim, nessa obra datada do século IV A.C., já há uma menção à necessidade de contabilizar fatores para imaginar o andamento das circunstâncias futuras. Para que se entenda a maneira com a qual Sunzi propõe a construção de cenários é preciso primeiro recorrer a alguns conceitos fundamentais que segundo o autor condicionam o ambiente.

Sunzi inicia a obra enumerando os cinco fatores que compõe a análise ambiental. É a partir dessas cinco forças ambientais que se "calculam" as variáveis e forças para os cenários de vitória ou de derrota. São elas:

1. O TAO " 道 ";

2. O Céu "天 ";

3. A Terra "地 ";

4. O Comando "特 "; e,

5. A Norma " 法 ".

Por TAO "道 " se entende "o caminho". Mas trata-se de um caminho diferente da idéia de caminho ocidental e ainda da idéia de caminho descrito no ideograma " 法 ". Não se trata de um caminho físico, trata-se sim de um caminho natural dos acontecimentos. Por exemplo: O TAO do mercado de automação bancária para suprir o sistema financeiro na década de noventa era o de franca expansão dada à revolução da informática. Daí poder-se dizer que uma empresa de informática que fizesse softwares para automação financeira nessa época estaria de acordo com o TAO "caminho natural dos acontecimentos", ou seja, agindo de acordo com a tendência natural dos fatos. Analisar comparativamente qual dos dois oponentes possui características e ações que estão de acordo com o TAO, o caminho natural dos acontecimentos, configura a análise da primeira força ambiental. 
Para Sunzi uma segunda instância ambiental a ser analisada é o Céu " 天 ". O Céu é a instância macroambiental, na qual todos os participantes na guerra estão inseridos. As condições que afetam todos os atores envolvidos na configuração de uma guerra. O Céu para Sunzi determina o "clima" do macroambiente analisado. Em conceitos empresariais modernos pode-se fazer uma analogia com os aspectos macroeconômicos, por exemplo.

A terceira instância a ser analisada é a Terra " 此 ". Aqui Sunzi se refere à idéia de terreno. É o campo imediato onde se trava a batalha - as dificuldades materiais, os acidentes, a sinuosidade. Em linguagem administrativa seria o ambiente operacional em que a empresa deverá atuar. É na Terra "地 ", ou no Terreno, que se encontram os exércitos aliados, oponentes, neutros, fornecedores de equipamentos, suprimentos e toda a gama de suporte à batalha. A Terra é a escala organizacional onde se manifesta a batalha.

A quarta instância a ser analisada é o Comando "梅 ". Aqui Sunzi trata dos generais que conduzirão a batalha no terreno. A habilidade tática, a liderança, a coragem, a astúcia. A versatilidade de comandar o exército. No mundo empresarial uma possível interpretação dessa instância está ligada à liderança e ao ambiente interno das empresas.

Também ligada aos aspectos internos do exército está à quinta força descrita por Sunzi: A Doutrina "法 ". Ela se refere aos aspectos culturais de um exército, à sua organização burocrática, as normas de comportamento, a lei. São as regras, a cultura organizacional, o ambiente interno dando vazão ao fluxo de movimentos imposto pelos comandantes.

Para Sunzi, deve-se analisar minuciosamente essas cinco instâncias em cada um dos dois exércitos oponentes. Assim, deve-se atribuir pontos aos dois exércitos em cada instância descrita acima, identificando forças e fraquezas de cada exército. Depois Sunzi trata de propor a análise e comparação dessas forças. Com elas em mãos torna-se 
possível inferir cenários de batalha. "夫未战而庙算胜者", (O nobre antes da guerra calcula a vitória no templo), Sunzi (2006, pg.32), se refere à necessidade de se comparar as variáveis das cinco instâncias ambientais entre os inimigos, e, a partir daí calcular as forças entre os dois exércitos. Com isso, emergem os possíveis cenários que configurarão os aspectos futuros da guerra. O uso específico de dois ideogramas " 庙 " e "算 ", nos mostra claramente a proposição de Sunzi. O ideograma "庙 " representa um templo e o ideograma " 算" representa um ábaco - que significa calcular. Quando se juntam os dois ideogramas forma-se a idéia de calcular no templo. Nesse caso específico, calcular cenários de vitória ou de derrota das batalhas em lugar sagrado, junto com os conselheiros e sábios.

Já no ocidente, Carl Von Clausewitz, um estrategista prussiano, escreveu em 1830 a obra militar denominada "Da Guerra". Nesta obra assentam-se e se consolidam os principais aspectos da tradição militar ocidental. Nela não há um capítulo ou menção direta aos métodos de construção de cenários, mas como na obra de Sunzi, existem fatores que devem ser analisados baseados em uma análise ambiental.

No capítulo II da obra "Da Guerra" de Clausewitz, denominado "Elementos da Estratégia", o estrategista ocidental enumera quais são os fatores a ser considerados tendo em vista o planejamento militar:

\footnotetext{
"As causas das condições no uso do engajamento estratégico podem ser convenientemente divididas em elementos de diferentes espécies, propriamente, a moral, a física, a matemática, a geografia e os elementos estatísticos. A primeira classe inclui tudo que se refere às qualidades e efeitos do mental e moral. Ao segundo pertence a magnitude da força militar, sua composição, proporção de armas, etc. O terceiro ao ângulo e as linhas de operação, movimentos concêntricos e excêntricos tão vastos quanto à natureza geométrica adquire nos valores calculados; para o quarto, a influência do terreno, assim como os pontos de comando, montanhas, rios, árvores, estradas; por último, o quinto, todos os elementos de suporte, etc." (CLAUSEWITZ, 1943, pg. 124) [Tradução do Autor].
} 
É a partir desses cinco elementos que o estrategista deve imaginar e planejar a batalha. Clausewitz recomenda a análise individual dos aspectos para depois elaborar sua interação mútua, de grande complexidade.

Para Clausewitz o primeiro elemento está ligado às circunstâncias abstratas da guerra, a moral e os aspectos mentais.

No segundo aspecto estão as quantidades materiais. Na tradição estratégica oriental as variantes quantitativas possuem menor destaque, ao passo que para Clausewitz elas são fundamentais.

O terceiro aspecto da análise ambiental do estrategista prussiano refere-se aos ângulos e às linhas de operação. Surge a quantificação matemática e geométrica da análise ambiental.

O aspecto geográfico aparece na quarta posição, possuindo um paralelo possível com aquilo que Sunzi chamou de "terreno".

Por fim ele enumera os elementos estatísticos que estão ligados ao suporte da batalha. É diferente de Sunzi que coloca como quinto elemento "A Doutrina" imposta ao exército. Embora as duas obras remetam à necessidade de organização interna do exército, essa organização se dá por meios completamente diferentes nos dois generais.

Em ambos os casos não há uma referência direta ou metodologia de construção especifica para cenários, mas sem dúvida pode-se notar nesses clássicos da estratégia militar a gênese da análise ambiental e da construção de cenários prospectivos. ${ }^{1}$

O uso sistemático dos cenários, cujo método pode ser considerado científico, remonta a Segunda Grande Guerra. Nessa época, muito se pesquisou sobre o futuro da tecnologia nuclear, radares e telecomunicações, entretanto, ainda não havia uso de cenários no universo corporativo.

\footnotetext{
${ }^{1}$ Segundo João Maurício Gama Boaventura [nos casos supracitados] não há uma variável fundamental para quem trabalha com cenários que é a questão do tempo. Falta uma lógica temporal nos estudos de cenários (pré-científicos) aqui apresentados.
} 
Na década de sessenta, a avaliação ambiental entrou em voga, e métodos de prospecção de cenários foram usados nas áreas de energia e mineração, conforme ilustram Tiley e Fuller (2000, pg.154).

Posteriormente, alguns acadêmicos valeram-se de tais técnicas para antever alguns comportamentos do mercado de energia pré-choques do petróleo, precisamente na década de setenta (HEIJDEN, 2004, pg.14) e (RINGLAND, 2006, pg.21).

Nesse contexto, os primeiros cenários foram classificados como sendo de "primeira geração". Os cenários de primeira geração caracterizaram-se como exploratórios, que buscavam fazer um mapeamento ambiental, ou seja, entender e refletir sobre as circunstâncias futuras sem o propósito de indicar estratégias de atuação. Posteriormente, "os cenários de segunda geração" deram um passo adiante, propondo, além do seu caráter ambiental-exploratório, uma provisão estratégica, ou seja, orientavam a ação, segundo Wack (1985, p. 78) e Georgantzas \& Acar (1995, p.29).

Nos anos oitenta, Ringland (op. cit., pg. 23) escreve que houve um declínio no interesse pelo planejamento em vista da sua euforia nos anos setenta. A desilusão em relação ao uso de cenários na década de oitenta foi a falência da "promessa dos cenários" para essa década - que mergulhara em profunda recessão, contrariando as expectativas prospectadas.

Já no final da década de oitenta uma nova classificação é proposta, dessa vez analisando metodologias já consagradas pelo uso empírico. Os dois troncos metodológicos de construção de cenários foram devidamente descritos: os cenários que partem do presente para a construção do futuro e os que partem de futuros imaginados e reconstroem enredos até o presente. Nesse sentido, os cenários segundo Dreborg (1996, pg. 814) possuem dois tipos de processo na sua elaboração, os de forecasting e os de backcasting.

Forecasting é um processo que parte do presente e atinge, através de métodos específicos, a elaboração de um ou vários cenários futuros. Portanto é a construção de cenários do presente para o futuro. 
Backcasting, em oposição, é o nome de um processo de elaboração de cenários em que se imagina primeiro os cenários futuros para em seguida refazer a seqüência de eventos e a lógica interna do futuro para o presente.

O final dos anos oitenta e início dos anos noventa foram anos de desenvolvimento e aprimoramento metodológico das técnicas de cenários. Pierre Wack (1985) descreveu o método de Lógica Intuitiva. Também foi descrito o método de Impacto Cruzado. O primeiro foi desenvolvido na Shell e leva em conta o conhecimento de especialistas para sua elaboração. O segundo se configura como um método que avalia os efeitos intrínsecos entre as variáveis-chaves, dando aos cenários um caráter complexo e relacional.

Atualmente existe mais de uma dezena de métodos de elaboração de cenários. Para uma melhor compreensão desses métodos o próximo tópico inicia a revisão de algumas tentativas de classificação dos métodos de construção de cenários, para então descrever aqueles tidos como os métodos principais.

\subsubsection{Tipologia atual e lógica interna dos cenários}

No tópico anterior descreveu-se de forma sucinta o surgimento dos métodos de construção de cenários através da sua cronologia histórica. Entretanto, por ter se difundido largamente do pós-guerra até o final do século $\mathrm{XX}$, os métodos primordiais de elaboração de cenários sofreram adaptações, modificações e aprimoramentos acarretando no surgimento de mais de uma dezena de métodos derivados ao longo desse período.

Tendo em vista esta miríade de métodos de construção de cenários algumas publicações contemporâneas procuraram organizar os cenários tipologicamente, ou ainda, segundo sua lógica interna. No importante artigo "An Updated scenario typology", publicado em 2003 na Futures, Notten et al., organizam de forma clara a tipologia dos cenários até então criados. 
O Quadro 1 coloca um resumo de uma classificação tipológica minuciosa de cenários, na qual divide os cenários em três grandes grupos de acordo com suas características temáticas. É uma classificação ligada às características morfológicas, como por exemplo, o fato do cenário ser exploratório ou de suporte à decisão. Outras duas categorias são postas, o estilo do processo de construção dos cenários e o seu grau de complexidade. O resumo da classificação tipológica segue abaixo:

Quadro 1 - Tipologia de cenários

\begin{tabular}{|c|c|c|c|}
\hline \multicolumn{2}{|c|}{ Temas gerais } & \multirow{2}{*}{\begin{tabular}{|l} 
Cenário \\
I.
\end{tabular}} & \multirow{2}{*}{$\begin{array}{l}\text { Características } \\
\text { Inclusão de normas? Descritivo versus } \\
\text { normativo. }\end{array}$} \\
\hline A & $\begin{array}{l}\text { Objetivo do projeto: exploratório } \\
\text { ou de suporte à decisão. }\end{array}$ & & \\
\hline & & II. & $\begin{array}{l}\text { Ponto de vantagem: Forecasting versus } \\
\text { backcasting }\end{array}$ \\
\hline & & III & $\begin{array}{l}\text { Tema: Baseado em assunto, baseado em } \\
\text { área, baseado em instituição }\end{array}$ \\
\hline & & IV. & $\begin{array}{l}\text { Escala de tempo: Longo prazo versus } \\
\text { curto prazo }\end{array}$ \\
\hline & & V. & $\begin{array}{l}\text { Escala espacial: Global, supranacional } \\
\text { versus nacional/local }\end{array}$ \\
\hline \multirow[t]{4}{*}{$\mathrm{B}$} & Estilo de processo & VI. & Dados: qualitativo versus quantitativo \\
\hline & & VII & $\begin{array}{lccc}\text { Método de } & \text { coleta } & \text { de dados: } \\
\text { Participatório } & \text { versus } & \text { pesquisa } & \text { de } \\
\text { gabinete } & & & \end{array}$ \\
\hline & & VIII & Recursos: extensos ou limitados \\
\hline & & IX. & $\begin{array}{l}\text { Condições institucionais: Aberta ou } \\
\text { restrita }\end{array}$ \\
\hline \multirow[t]{5}{*}{$\mathrm{C}$} & $\begin{array}{l}\text { Conteúdo do cenário: } \\
\text { complexo versus simples }\end{array}$ & $\mathrm{X}$. & $\begin{array}{l}\text { Tempo natural: (claim) assertivo ou } \\
\text { instantâneo (snapshot) }\end{array}$ \\
\hline & & $\mathrm{XI}$ & $\begin{array}{lll}\text { Variáveis: } & \text { Heterogêneas } & \text { ou } \\
\text { homogêneas } & & \\
\end{array}$ \\
\hline & & XII & $\begin{array}{lll}\text { Dinâmico: } & \text { Periférico } & \text { versus } \\
\text { tendencioso } & & \\
\end{array}$ \\
\hline & & XIII & $\begin{array}{l}\text { Amplitude de desvio: Alternativo } \\
\text { versus convencional }\end{array}$ \\
\hline & & XIV & Grau de integração \\
\hline
\end{tabular}

Fonte: NOTTEN et al., 2003, pg.426 
Em 2005, Ron Bradfield, George Wright, George Burt, George Cairns e Kees Van Der Heijden publicaram na Futures um artigo denominado "The origins and evolution of scenario techniques in long range business planning" (As origens e a evolução das técnicas de cenários em negócios de planejamento à longo prazo) [trad. do autor] com o intuito de organizar os métodos de cenários surgidos até então.

Nesse artigo, explora-se o histórico do surgimento dos métodos de cenários a partir da tradição Francesa e Norte Americana do pós-guerra. Tais tradições de pensamento foram o gérmen dos métodos mais recentes de cenários, visto que ganharam ali seu caráter científico.

A tradição norte americana no desenvolvimento de cenários foi uma resposta às necessidades do departamento de defesa Norte Americano frente aos desafios de lidar com sistemas de armamentos complexos e sofisticados, principalmente porque a eficiência e a eficácia desse arsenal dependiam do grau de sofisticação dos armamentos dos exércitos inimigos. Surgiram então os métodos computacionais e a técnica de Delphi para tentar dar conta de tais problemas. Estes deram origem a duas escolas norte americanas de construção de cenários.

1. Escola da Lógica Intuitiva (The intuitive logic school) [trad. do autor]

2. Escola das Tendências Probabilísticas (Probabilistic Modified Trends School) [trad. do autor].

Enquanto isso, do outro lado do Atlântico, na França, um filósofo francês chamado Berger cria um método de construção de cenários para lidar com problemas de política pública, método esse que é aprimorado posteriormente por Godet. A escola ( $\mathrm{L} a$ Prospective) definiu métodos parecidos com o da lógica intuitiva, embora mais sofisticados. Enquanto as escolas de cenário norte americanas tinham seus interesses voltados aos cenários geopolíticos e internacionais a escola francesa se voltou aos problemas internos de seu país.

O Quadro 2 ilustra os aspectos dessas três escolas que deram origem e classificam a grande maioria dos métodos de cenários vigentes partindo de uma perspectiva historiográfica: 
Quadro 2 - Comparação dos aspectos mais importantes das três escolas de métodos de cenários

\begin{tabular}{|c|c|c|c|}
\hline & Lógica Intuitiva & La Prospective & $\begin{array}{c}\text { Método de Tendência } \\
\text { Probabilística }\end{array}$ \\
\hline $\begin{array}{l}\text { Propósito de trabalho } \\
\text { do cenário }\end{array}$ & 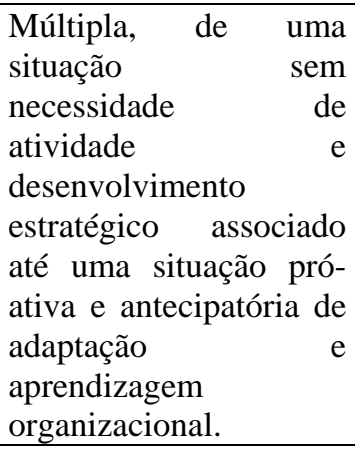 & $\begin{array}{l}\text { Usualmente associada } \\
\text { com o desenvolvimento } \\
\text { mais efetivo de } \\
\text { atividades sem } \\
\text { necessidade de ação } \\
\text { mais voltadas para } \\
\text { formulação de políticas } \\
\text { e decisões táticas e } \\
\text { estratégias em planos } \\
\text { de ação. }\end{array}$ & $\begin{array}{lr}\text { De uma } & \text { once-off } \\
\text { activity à } & \text { predição } \\
\text { extrapolativa } & \text { e } \\
\text { avaliação política. }\end{array}$ \\
\hline Perspectiva de Cenário & $\begin{array}{l}\text { Descritiva } \\
\text { normativa. }\end{array}$ & $\begin{array}{l}\text { Usualmente descritiva } \\
\text { podendo ser normativa. }\end{array}$ & Descritiva. \\
\hline Escopo de atuação & $\begin{array}{l}\text { Pode ser amplo ou } \\
\text { restrito atuando do } \\
\text { global ao regional. De } \\
\text { país ou indústria para } \\
\text { um foco específico. }\end{array}$ & $\begin{array}{l}\text { Geralmente um escopo } \\
\text { restrito, mas que } \\
\text { considera uma vasta } \\
\text { gama de fatores em sua } \\
\text { análise. }\end{array}$ & $\begin{array}{l}\text { Escopo restrito, focado } \\
\text { na probabilidade e } \\
\text { impacto de eventos } \\
\text { específicos do histórico } \\
\text { de tendências. }\end{array}$ \\
\hline Horizonte anual & Amplitude: 3-20 anos. & Amplitude: 3-20 anos. & Amplitude: 3-20 anos. \\
\hline $\begin{array}{l}\text { Orientação } \\
\text { Metodológica }\end{array}$ & $\begin{array}{l}\text { Processo de orientação: } \\
\text { Indutivo ou dedutivo, } \\
\text { essencialmente } \\
\text { subjetivo e qualitativo } \\
\text { na aproximação, } \\
\text { confiando em uma } \\
\text { intuição disciplinada. }\end{array}$ & $\begin{array}{l}\text { Processo de orientação: } \\
\text { Direto e objetivo, } \\
\text { quantitativo e analítico. } \\
\text { com alguma } \\
\text { subjetividade. }\end{array}$ & $\begin{array}{l}\begin{array}{l}\text { Processo de } \\
\text { direto erientação } \\
\text { quantitativo e }\end{array} \text { abjetivo, } \\
\text { (comalítico } \\
\text { alguma } \\
\text { subjetividade) fazendo } \\
\text { uso de extrapolações } \\
\text { baseadas em métodos } \\
\text { computacionais durante } \\
\text { a realização de } \\
\text { previsões e simulações. }\end{array}$ \\
\hline $\begin{array}{l}\text { Natureza do time de } \\
\text { participantes do cenário }\end{array}$ & $\begin{array}{l}\text { Interna - } \text { Cenários } \\
\text { desenvolvidos por um } \\
\text { time de facilitadores da } \\
\text { própria organização. }\end{array}$ & $\begin{array}{l}\text { Combinação de alguns } \\
\text { indivíduos-chave da } \\
\text { própria organização } \\
\text { com especialista } \\
\text { externo que lidera o } \\
\text { processo. }\end{array}$ & $\begin{array}{l}\text { Externo - A elaboração } \\
\text { dos cenários é } \\
\text { conduzida por um } \\
\text { especialista externo. }\end{array}$ \\
\hline $\begin{array}{l}\text { Praxe de especialistas } \\
\text { externos }\end{array}$ & $\begin{array}{l}\text { Cenaristas experientes } \\
\text { projetam e facilitam o } \\
\text { processo. É comum a } \\
\text { consulta de pessoas } \\
\text { luminares para catalisar } \\
\text { novas idéias. }\end{array}$ & 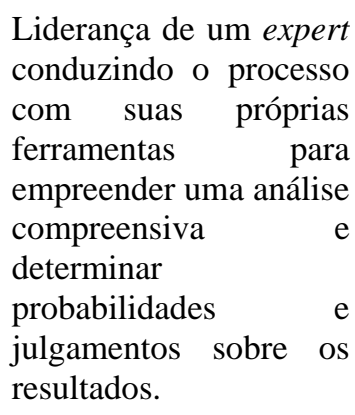 & $\begin{array}{l}\text { Liderança de um expert } \\
\text { conduzindo o processo } \\
\text { com suas próprias } \\
\text { ferramentas } \\
\text { julgamentos a fim de } \\
\text { identificar eventos } \\
\text { futuros de alto impacto } \\
\text { sem precedentes e suas } \\
\text { probabilidades } \\
\text { ocorrência. }\end{array}$ \\
\hline
\end{tabular}




\begin{tabular}{|c|c|c|c|}
\hline & Lógica Intuitiva & La Prospective & $\begin{array}{l}\text { Método de Tendência } \\
\text { Probabilística }\end{array}$ \\
\hline $\begin{array}{l}\text { Ferramentas } \\
\text { comumente usadas }\end{array}$ & $\begin{array}{l}\text { Genéricas - Brainstorm, } \\
\text { matrizes, sistemas } \\
\text { dinâmicos e análises de } \\
\text { stakeholders. }\end{array}$ & $\begin{array}{l}\text { Próprias - (Micmac) e } \\
\text { (Mactor) analysis, } \\
\text { análise morfológica, } \\
\text { Delphi, SMIC Prob- } \\
\text { Expert, Multipol, } \\
\text { avaliação multicriterial. }\end{array}$ & $\begin{array}{l}\text { Próprias - Tendência de } \\
\text { impactos e análise de } \\
\text { impactos cruzados e } \\
\text { simulações Monte } \\
\text { Carlo. }\end{array}$ \\
\hline $\begin{array}{l}\text { Ponto de início do } \\
\text { cenário }\end{array}$ & $\begin{array}{l}\text { Uma decisão } \\
\text { administrativa, } \\
\text { problema ou área de } \\
\text { interesse comum. }\end{array}$ & $\begin{array}{l}\text { Um fenômeno } \\
\text { específico ligado a uma } \\
\text { preocupação comum. }\end{array}$ & $\begin{array}{l}\text { Decisões e problemas } \\
\text { que possuam dados } \\
\text { temporais detalhados e } \\
\text { confiáveis. }\end{array}$ \\
\hline $\begin{array}{l}\text { Identificação de forças } \\
\text { motrizes }\end{array}$ & $\begin{array}{l}\text { Intuição - Técnicas de } \\
\text { brainstorm, análise de } \\
\text { fatores de base, } \\
\text { pesquisa e consulta com } \\
\text { pessoas relevantes } \\
\text { ligadas ao tema. }\end{array}$ & $\begin{array}{lr}\text { Entrevista com atores } \\
\text { do fenômeno estudado } \\
\text { e análise } & \text { estrutural } \\
\text { usando } & \text { softwares } \\
\text { sofisticados. } & \end{array}$ & $\begin{array}{l}\text { Traçado de curvas em } \\
\text { séries históricas para } \\
\text { identificar tendências e } \\
\text { uso de opiniões de } \\
\text { experts para criar uma } \\
\text { base de dados dos } \\
\text { potenciais futuros } \\
\text { impactos } \\
\text { precedentes. }\end{array}$ \\
\hline $\begin{array}{ll}\text { Estabelecimento } & \text { de } \\
\text { palco do cenário } & \end{array}$ & $\begin{array}{l}\text { Definindo a lógica dos } \\
\text { cenários como a sua } \\
\text { organização temática ou } \\
\text { princípios } \\
\text { (freqüentemente } \\
\text { forma de matrizes). }\end{array}$ & $\begin{array}{l}\text { Matrizes de conjuntos } \\
\text { de eventos prováveis } \\
\text { baseadas em variáveis- } \\
\text { chaves para o futuro. }\end{array}$ & $\begin{array}{l}\text { Simulações } \\
\text { Carlo para criar uma } \\
\text { atmosfera de incerteza } \\
\text { ao redor do cenário- } \\
\text { base enquanto indicador } \\
\text { principal. }\end{array}$ \\
\hline $\begin{array}{l}\text { Exercício de resultado } \\
\text { do cenário }\end{array}$ & $\begin{array}{l}\text { Qualitativo - Conjunto } \\
\text { de cenários igualmente } \\
\text { plausíveis no discurso } \\
\text { narrativo apoiado por } \\
\text { gráficos e alguma } \\
\text { quantificação. } \\
\text { Implicações, opções } \\
\text { estratégicas e sinais de } \\
\text { aviso incrementando o } \\
\text { resultado. }\end{array}$ & $\begin{array}{lr}\text { Quantitativo } & \text { e } \\
\text { qualitativo - } & \text { cenários } \\
\text { múltiplos de } & \text { futuros } \\
\text { alternativos } & \text { baseados } \\
\text { em } & \text { análises } \\
\text { compreensivas } & \text { que } \\
\text { incorporam possíveis } \\
\text { ações e } & \text { suas } \\
\text { conseqüências. } & \end{array}$ & $\begin{array}{l}\text { Quantitativo - Há um } \\
\text { cenário base e cenários } \\
\text { adjacentes baseados nos } \\
\text { quartis estatísticos das } \\
\text { séries temporais. Pode } \\
\text { ser ilustrado com } \\
\text { histórias curtas que } \\
\text { ajudam a explicar o } \\
\text { cenário. }\end{array}$ \\
\hline $\begin{array}{l}\text { Probabilidades ligadas } \\
\text { ao cenário }\end{array}$ & $\begin{array}{l}\text { Não, todos os cenários } \\
\text { tem a a mesma } \\
\text { probabilidade. }\end{array}$ & $\begin{array}{l}\text { Sim, a probabilidade da } \\
\text { evolução das variáveis } \\
\text { estão sob a suposição } \\
\text { do comportamento dos } \\
\text { atores envolvidos. }\end{array}$ & $\begin{array}{l}\text { Sim, condiciona a } \\
\text { probabilidade de } \\
\text { ocorrência de eventos } \\
\text { sem precedentes e de } \\
\text { ruptura. }\end{array}$ \\
\hline $\begin{array}{l}\text { Número de cenários } \\
\text { gerados }\end{array}$ & Geralmente de 2 a 4. & Variado. & $\begin{array}{l}\text { Usualmente de } 3 \text { a } 6 \text {, } \\
\text { dependendo do número } \\
\text { de simulações. }\end{array}$ \\
\hline $\begin{array}{l}\text { Critério de avaliação } \\
\text { dos cenários }\end{array}$ & $\begin{array}{l}\text { Coerência, clareza, } \\
\text { consistência interna, } \\
\text { estrutura analítica e } \\
\text { lógica. Todos os } \\
\text { cenários são igualmente } \\
\text { plausíveis. }\end{array}$ & $\begin{array}{lr}\text { Coerência, } & \text { clareza, } \\
\text { consistência } & \text { interna. } \\
\text { Rigorosa } & \text { estrutura } \\
\text { matemática, } & \text { Cenários } \\
\text { plausíveis e verificáveis } \\
\text { em retrospecto. }\end{array}$ & $\begin{array}{l}\text { Cenários plausíveis e } \\
\text { verificáveis em } \\
\text { retrospecto. }\end{array}$ \\
\hline
\end{tabular}

Fonte: BRADFIELD et all, 2005, pg.807 
É notável que nos últimos cinco anos, vários autores têm realizado um trabalho sistemático de ordenar e classificar os métodos de construção de cenários. As formas de classificação são diversas. Para Börjeson et al. (2006, pg.723) essa classificação pode ser feita em três categorias e seis tipos. Os cenários podem ser preditivos, extrapolativos e normativos. Os cenários preditivos procuram antever eventos futuros, basicamente através de forecasts ou previsões baseadas em suposições a respeito de variáveis "e se acontecer o evento determinado?" Os cenários extrapolativos estão baseados em responder a pergunta: "o que pode acontecer?". Sobre essa reflexão os cenários se dividem em duas categorias: Os externos e os estratégicos. Os externos respondem sobre o que pode acontecer com fatores que ocorrem no ambiente estudado, sem propor ação, por outro lado, os estratégicos respondem "caso se aja de certa forma, o que acontecerá?". Por fim os cenários normativos estão ligados ao atingir de metas. Eles se subdividem em cenários preservacionistas e transformadores. Os cenários preservacionistas buscam o cumprimento de um objetivo através do mínimo esforço possível. Já os transformadores trabalham de forma análoga aos cenários de backcasting, e se pressupõe que o objetivo futuro não será alcançado da forma com que se atua no presente. Cabe aos cenaristas, portanto, criar uma ruptura no curso dos eventos e decisões, a fim de construir um caminho para se chegar lá. A tabela abaixo descreve em maiores detalhes a classificação proposta: 
Quadro 3 - Resumo dos principais aspectos tipológicos dos cenários

\begin{tabular}{|c|c|c|c|c|}
\hline $\begin{array}{l}\text { Categoria e tipo } \\
\text { de cenário }\end{array}$ & $\begin{array}{l}\text { Quantitativo } \\
\text { Qualitativo }\end{array}$ & Escopo de tempo & $\begin{array}{l}\text { Estrutura de } \\
\text { sistema }\end{array}$ & $\begin{array}{lr}\text { Foco em } & \text { fatores } \\
\text { internos } & \text { ou } \\
\text { externos } & \\
\end{array}$ \\
\hline \multicolumn{5}{|l|}{$\begin{array}{l}\text { Preditivo - "o que } \\
\text { irá acontecer? }\end{array}$} \\
\hline Forecasts & $\begin{array}{l}\text { Tipicamente } \\
\text { quantitativo, às } \\
\text { vezes qualitativo. }\end{array}$ & $\begin{array}{l}\text { Normalmente } \\
\text { curto }\end{array}$ & Tipicamente um & $\begin{array}{l}\text { Tipicamente } \\
\text { externo }\end{array}$ \\
\hline E se? & $\begin{array}{l}\text { Tipicamente } \\
\text { quantitativo, às } \\
\text { vezes qualitativo. }\end{array}$ & $\begin{array}{l}\text { Normalmente } \\
\text { curto }\end{array}$ & De um à vários & $\begin{array}{l}\text { Externo e, } \\
\text { possivelmente, } \\
\text { interno. }\end{array}$ \\
\hline \multicolumn{5}{|l|}{$\begin{array}{l}\text { Explorativo "o } \\
\text { que pode } \\
\text { acontecer?" }\end{array}$} \\
\hline Externo & $\begin{array}{l}\text { Tipicamente } \\
\text { qualitativo, } \\
\text { quantitativamente } \\
\text { possível. }\end{array}$ & $\begin{array}{l}\text { Normalmente } \\
\text { longo }\end{array}$ & $\begin{array}{l}\text { Normalmente } \\
\text { severo }\end{array}$ & Externo \\
\hline Estratégico & $\begin{array}{l}\text { Qualitativo e } \\
\text { quantitativo. }\end{array}$ & $\begin{array}{l}\text { Normalmente } \\
\text { longo }\end{array}$ & $\begin{array}{l}\text { Normalmente } \\
\text { severo }\end{array}$ & $\begin{array}{lr}\text { Interno } & \text { sobre } \\
\text { influência } & \text { do } \\
\text { externo } & \end{array}$ \\
\hline \multicolumn{5}{|l|}{$\begin{array}{lr}\text { Normativo } & \text { "como } \\
\text { um certo objetivo } \\
\text { pode } & \text { ser } \\
\text { alcançado" } & \end{array}$} \\
\hline Preservacionista & $\begin{array}{l}\text { Tipicamente } \\
\text { Quantitativo }\end{array}$ & $\begin{array}{l}\text { Normalmente } \\
\text { longo }\end{array}$ & $\mathrm{Um}$ & $\begin{array}{l}\text { Ambos, externo } \\
\text { ou interno }\end{array}$ \\
\hline Transformador & $\begin{array}{ll}\text { Tipicamente } & \\
\text { qualitativo com } \\
\text { elementos } & \\
\text { quantitativos } & \end{array}$ & $\begin{array}{l}\text { Normalmente } \\
\text { muito longo }\end{array}$ & $\begin{array}{l}\text { Mudando, pode } \\
\text { ser severo }\end{array}$ & Não aplicável \\
\hline
\end{tabular}

Fonte: BÖRJESON et all., 2006, pg.723

\subsubsection{Métodos de Construção de Cenários}

Depois de expor a tipologia e a lógica interna da construção de cenários, serão descritos os métodos mais usados de construção dos cenários.

Durante esta revisão teórica, foram identificados dez métodos para construção de cenários na literatura, a saber: (1) SRI - Stanford Research Institute, (2) Análise Prospectiva, (3) Battelle Memorial Institute, (4) Comprehensive Situation Mapping, (5) Future Mapping, (6) Análise de Impactos de Tendências, (7) GBN - Global Business Network, (8) DSI - Decision Strategies International. Alia-se a estes nove o método de 
geração de variáveis-chaves de Boaventura, Costa e Fischmann, que será utilizado nesse trabalho, descrito em detalhes no item 2.2.5

\subsubsection{SRI - Stanford Research Institute}

O modelo chamado de SRI foi desenvolvido pela Shell na década de setenta e emprega a lógica intuitiva no seu modelo de construção. Segundo Schwartz (1995, pg.21), o trabalho de planejamento de cenários ganhou novo fôlego com o resultado do trabalho de Pierre Wack da Shell. Pela primeira vez os cenários foram construídos para mudar a visão dos diretores de uma empresa. O foco mudou da prospecção de um futuro plausível para, na verdade, servir de base à reflexão estratégica. O sentido de se fazer cenários, com essa experiência da Shell, mudou. Pensar um universo de possibilidades se tornara mais importante que acertar uma previsão ou propriamente prospectar um futuro plausível. Para elaborar esse novo paradigma na construção de cenários, Wack dotou sua metodologia do que chamara de Lógica Intuitiva, que foi dividida em oito etapas:

1. Identificar a decisão estratégica principal;

2. Especificar as principais forças do ambiente local;

3. Identificar e analisar as forças motrizes;

4. Elaborar um ranking por importância e incerteza;

5. Selecionar e estabelecer a lógica dos cenários;

6. Detalhar os cenários;

7. Interpretar as implicações dos cenários; e

8. Selecionar os principais indicadores.

Wilson (1998, pg.81) descreve a idéia central desse modelo, de construção de cenários:

[...] O modelo é intuitivo no sentido que constrói sobre impressões e asserções sobre a incerteza e possíveis declarações de pessoas que possuam conhecimento [...] Mas o modelo também é lógico, formal e disciplinado no seu trato com a informação, análise e estrutura com que realiza sua tarefa. [trad. do autor]

Para que esse modelo seja bem sucedido, Wilson (Ibden., pg.90) recomenda que não se construa muitos cenários durante o processo, pois se perde objetividade. O nome do cenário também deve ser sintético e denso de significado, além de criar cenários realmente criativos que quebrem o modelo mental pré-estabelecido. 


\subsubsection{Análise Prospectiva}

O modelo de Análise Prospectiva é um modelo da escola francesa, criado por Michel Godet no final da década de setenta. O modelo foi aperfeiçoado na década de oitenta pelo Conservatoire National des Arts et Métiers, em Paris (GODET e ROUBELAT, 1996). Essa abordagem usa a lógica do modelo de cenários desenvolvido pela DATAR em conjunto com as ferramentas criadas nos anos sessenta nos EUA de Impacto Cruzado e Análise de Impactos Tendenciais.

Godet (1993, pg. 22) expõe que a idéia central do modelo é criar futuros totalmente diferentes do passado, visto que os problemas mudam muito depressa sendo essa velocidade por vezes maior que o alcance da capacidade de solucioná-los. Considera também que o futuro é indeterminado.

Entretanto a Análise Prospectiva visa apenas reduzir a incerteza e fazer com que se tomem decisões rumo a um futuro desejado.

Essa metodologia elabora cenários que servirão de ferramenta para tomada de decisões estratégicas.

As etapas de elaboração de cenários segundo esse modelo são:

1. Análise do problema e delimitação do sistema;

2. Diagnóstico da empresa;

3. Análise Estrutural;

4. Dinâmica da empresa no ambiente;

5. Cenários ambientais;

6. Identificação de Estratégias;

7. Avaliação de estratégias;

8. Seleção de estratégias; e

9. Planos de monitoração da estratégia.

Os principais objetivos da construção de cenários pela Análise Prospectiva são revelar e estudar as variáveis-chaves do ambiente, determinar os agentes fundamentais desse 
ambiente, descrever sob forma de cenários o sistema estudado e formular estratégias a partir de tais cenários.

\subsubsection{Battelle Memorial Institute}

A abordagem da Battelle é, na verdade, uma variação do método de Análise de Impacto Cruzado, que busca entender os efeitos complexos das variáveis ambientais, assim como suas inter-relações (MILLETT, 1992, pg.22). A idéia fundamental dessa metodologia é coletar dados e processá-los em um software (BASICS) para que se forme, a partir desses resultados, o esqueleto dos cenários a serem descritos.

A metodologia BASICS é composta de sete etapas, conforme mostram Huss e Honton (1987, pg.26):

1. Definir a estrutura do assunto a ser pesquisado, incluindo unidades de medida, amplitude de tempo e escopo geográfico;

2. Identificar e estruturar as áreas de influência;

3. Definir os descritores, escrever o ensaio de cada descritor e atribuir probabilidades iniciais de ocorrência de cada estado dos descritores;

4. Completar a Matriz de Impacto Cruzado e rodar o programa BASICS;

5. Selecionar cenários para estudo mais detalhado e elaborar a narrativa dos mesmos;

6. Introduzir eventos de baixa probabilidade, mas com alto impacto, e conduzir uma análise de sensibilidade; e

7. Elaborar os futuros projetados nos cenários e avaliar suas implicações.

Entre as vantagens dessa abordagem, está a possibilidade de classificação dos cenários segundo sua probabilidade relativa de ocorrência e a possibilidade de análises de sensibilidade (das variáveis) visto que o rápido processamento em computador permite rodar muitas simulações em curto espaço de tempo.

\subsubsection{Comprehensive Situation Mapping}

O CSM - Comprehensive Situation Mapping é um método de geração de cenários desenvolvido por Willian Acar em 1983. Esse método combina as vantagens do mapeamento de métodos mentais com o uso de computadores. É especialmente eficaz 
no processamento de situações muito complexas visto que a análise das variáveis não se faz em partes, mas de forma integral.

GEORGANTZAS e ACAR (Op. cit., pg. 144) definem as etapas do método:

1. Fase divergente: Primeiro, a visão particular de cada tomador de decisão na circunstância estudada é coletada individualmente. Dessas visões são elaborados os primeiros esboços dos cenários.

2. Fase convergente: Nessa segunda fase, todos os envolvidos são reunidos para debater as diferenças, analisar as possibilidades e hipóteses na tentativa de encontrar consenso. A idéia é estimular a imaginação através da comunicação direta.

A grande vantagem desse método é o fato de aliar as nuances da percepção humana às técnicas computacionais, pois na medida em que dá liberdade para a criatividade na captação de modelos mentais, também cria diagramas através de funções matemáticas, permitindo uma avaliação abrangente e complexa na elaboração dos cenários. A fase convergente, vale notar, proporciona uma análise holística da situação.

\subsubsection{Future Mapping}

O método de construção de cenários proposto pelo Future Mapping foi desenvolvido por David Mason e é uma técnica simples de construção de cenários se comparada às técnicas complexas de modelagem computacional. Segundo Mason (1994, pg.8), o Future Mapping tem características operacionais comuns à lógica intuitiva usada na SRI - Stanford Research Institute. O método prescinde de encontros de grupo coordenados por especialistas, nos quais, os executivos constroem os cenários a partir dos materiais de apoio fornecidos.

O método conta com as seguintes etapas, conforme aponta MASON (Op. cit., pg. 9):

1. Criar imagens finais e eventos que conduzem a ela (de 100 a 180);

2. Definir cenário convencional;

3. Selecionar grupos para cada imagem; 
4. Cada grupo escolhe os eventos que conduzem à imagem final;

5. Cada grupo apresenta seu cenário;

6. Análise dos elementos comuns e divergentes;

7. Escolha da imagem final; e

8. Definição estratégica.

MASON (1998, pg. 110) aponta entre as vantagens desse método para as organizações, o fato de haver a construção de uma seqüência de eventos clara no caminho a ser percorrido pela empresa rumo à imagem do cenário final, além de apontar claramente os eventos importantes para cada imagem final, possibilitando uma análise particular deles.

\subsubsection{Análise de Impactos de Tendências}

Esse método de construção de cenários teve início no Futures Group, uma empresa Americana que atuou na década de 70. Segundo Ringland (1998, pg.223) tal método se baseia na projeção de variáveis-chaves sobre as quais serão analisados os seus respectivos impactos.

O método, segundo o mesmo autor (Op. cit., pg. 223) se divide nas seguintes etapas:
a) Preparação
1. Definição de foco; e
2. Identificação de forças motrizes
b) Desenvolvimento
1. Elaboração de Cenários;
2. Escolha dos cenários alternativos; e
3. Projeções para cada cenário.
c) Apresentação
1. Documentação; e
2. Comprovação 
Segundo Bontempo (2000, pg.150), esse método se baseia em modelos econométricos e técnicas de análise computacionais. O uso de modelos quantitativos é importante para a formalização de hipóteses e para fase de documentação na elaboração dos cenários.

\subsubsection{GBN - Global Business Network}

O Global Business Network é um método semelhante ao SRI, visto que usa a lógica intuitiva na sua metodologia e tem uma origem comum em relação a esse outro método. Peter Schwartz trabalhava na SRI antes de propor o método GBN. As etapas do GBN, segundo Ringland (2006, pg.208), são:

1. Identificar o foco de decisão;

2. Identificar as forças chave no ambiente local;

3. Eleger as forças motrizes;

4. Hierarquizar as forças por importância e incerteza;

5. Selecionar a lógica dos cenários;

6. Dar corpo aos cenários;

7. Implicações;

8. Seleção de indicadores e sinais.

O próprio autor que criara o método, Schwartz (2000, pg. 204), alerta sobre a utilização do GBN, no sentido de que se tome cuidado com a elaboração de três cenários, uma vez que o intermediário é passível de ser visto como mais provável, quando isso não é necessariamente uma verdade. Diz também para que se evite atribuir probabilidades aos cenários. Uma atenção especial com os nomes deve ser tomada. A participação das esferas de decisão, pessoas com funções heterogêneas e criativas também é altamente recomendável.

\subsubsection{DSI - Decision Strategies International}

O DSI, Decision Strategies International é um método de construção de cenários que também nasceu na Shell, através do trabalho de Shoemaker. Como nos métodos que tiveram suas origens ligadas à Shell e ao pioneirismo de Pierre Wack, baseia-se na lógica intuitiva para elaboração dos seus cenários. Entretanto, parte-se de uma classificação inicial sobre as variáveis-chaves das quais se têm algum conhecimento e as 
que são incertas. O processo do DSI, de acordo com Shoemaker (1993, p. 28), passa pelas seguintes etapas:
1. Definição de Escopo;
2. Identificação dos Stakeholders;
3. Identificação das tendências básicas;
4. Identificação das incertezas-chave;
5. Construção de cenários forçados;
6. Checagem de consistência e plausibilidade;
7. Desenvolvimento de cenários de aprendizagem;
8. Identificação de necessidade de pesquisa;
9. Desenvolvimento de métodos quantitativos; e
10. Seleção de cenários de decisão.

Um aspecto interessante dessa metodologia está no fato dela possuir uma etapa de verificação de consistência dos cenários; em relação ao escopo e prazos abordados, entre os estados finais das incertezas assumidas e às posições tomadas pelos stakeholders (SHOEMAKER, 1995, pg.29). Outra nota importante reside no significado do tópico 7 - cenários de aprendizagem. Além de Shoemaker, Schwartz e Olgivy apontam que "Cenários são também uma ferramenta de aprendizagem para investigação em diversas áreas de risco e oportunidade..." (SCHWARTZ e OLGIVY, 1998, pg.59). Isso significa dizer que construir cenários é um exercício importante de pensamento exploratório sobre os mais diversos assuntos e pode ser utilizado para que uma organização aprenda a respeito do comportamento de um mercado, sobre a cultura política de um país ou ainda sobre o futuro de uma tecnologia de comunicação. Portanto, é possível usar a técnica de cenários e sua análise ambiental para que se acumule conhecimento sobre um assunto que seja pertinente para uma organização, caracterizando essa atividade como elaboração de cenários de aprendizagem.

\subsubsection{Método de Boaventura, Costa e Fischmann}

Considerando os métodos já descritos, torna-se evidente que existem elementos básicos para construção de cenários independente do método abordado. É cabível, assim, assumir que tais elementos sejam comuns a vários métodos - inclusive nos descritos anteriormente. Um dos elementos fundamentais na elaboração de cenários, ao 
analisarmos os diversos métodos, é a análise das tendências e incertezas ambientais, ou seja, as variáveis-chaves do processo de elaboração de cenários, conforme ilustram Boaventura et al. (2008, pg.89):

[...]Nota-se que diversos modelos de cenários incluem uma análise do ambiente em seu processo, procurando descrever como os componentes do ambiente poderão se comportar no futuro. Exemplo disso pode ser encontrado nos modelos: SRI - Ringland (1998, pg. 248); GBN Schwartz (2000, p.200); Future Mapping - Mason (1994, p.8) e Battelle, Huss e Honton (1987, pg.26); Análise Prospectiva - Godet (2000, pg.27); Comprehesive Situation Mapping Georgantzas e Acar (1995, p.306) e Análise do Impacto de Tendências - Ringland (1998, p. 223). [...] É válido, portanto, abordar o conceito de tendências e incertezas como variáveis necessárias para construção de cenários.

Shoemaker (Op. cit., pg.35) apresenta uma figura que ilustra a maneira pela qual as tendências e incertezas influenciam na construção dos cenários - Figura 1:

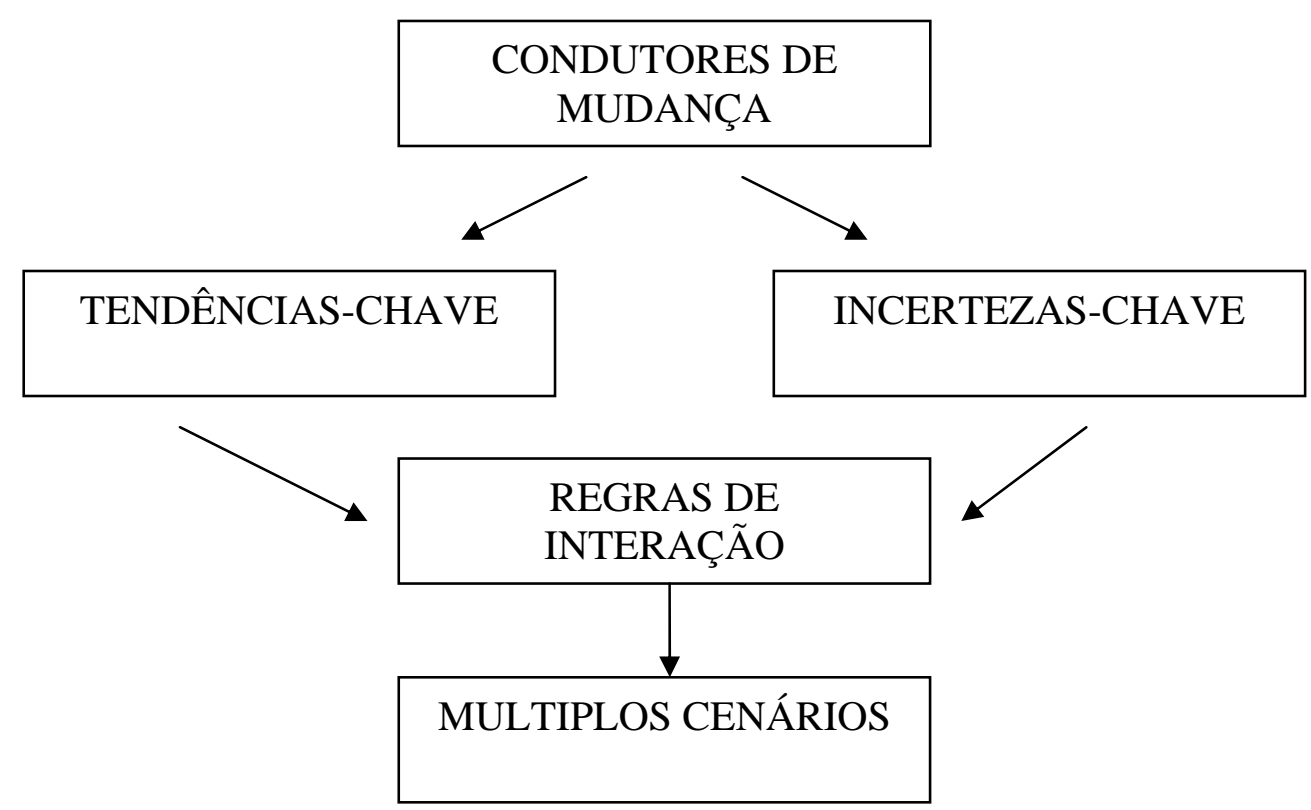

Figura 1. Condutores de mudança.

Fonte: SHOEMAKER, 1995, pg. 35.

As tendências e incertezas, portanto, configuram o cerne das metodologias de construção de cenários. É a partir do possível comportamento das variáveis-chaves que o cenarista elabora os roteiros futuros. Boaventura et al. (2008, pg. 91) enfatiza que "a determinação das variáveis-chaves compreende uma etapa crítica na elaboração de cenários, pois estas, a princípio, devem permitir a definição de cenários de contraste". Entenda-se por cenários de contraste os diferentes cenários que se formam à medida que 
se alteram as variáveis-chaves. Torna-se claro entender a importância do contraste entre os cenários quando se atenta para o fato de que caso não haja tais diferenças, possíveis mudanças no ambiente que afetam potencialmente a empresa podem estar sendo desconsideradas. Ou seja, corre-se o risco de que sejam construídos cenários muito próximos ou equivalentes, quando na verdade o ideal é que eles sejam diversos e constrastantes.

Tendo em vista tais aspectos surge naturalmente a indagação de como se torna possível encontrar as variáveis-chaves durante a elaboração de cenários. Na verdade, o ambiente de uma organização é um sistema influenciado por stakeholders. Portanto, nada mais apropriado que considerar as possibilidades de ação destes stakeholders. Descobrir quais são as variáveis-chaves do sistema passa por investigar quem são os stakeholders, e quais os especialistas que os conhecem a fundo, visto que eles poderão, através de questionários, fornecerem ao cenarista os elementos para identificar as variáveis-chaves e atribuir a elas suas devidas relevâncias.

Embora a identificação dos stakeholders não seja suficiente para o conhecimento do ambiente, ela é um caminho para que isso ocorra. A técnica de análise de stakeholders foi descrita por MITROFF e EMSHOFF (1979, pg.6).

Baseados na técnica de análise ambiental através da identificação dos stakeholders, Boaventura, Costa e Fischmann (2008) propuseram um método para se encontrar as variáveis-chaves de um ambiente estudado, levando em consideração o processo de stakeholder analysis.

O processo consiste em quatro etapas fundamentais, conforme ilustra a Figura 2:

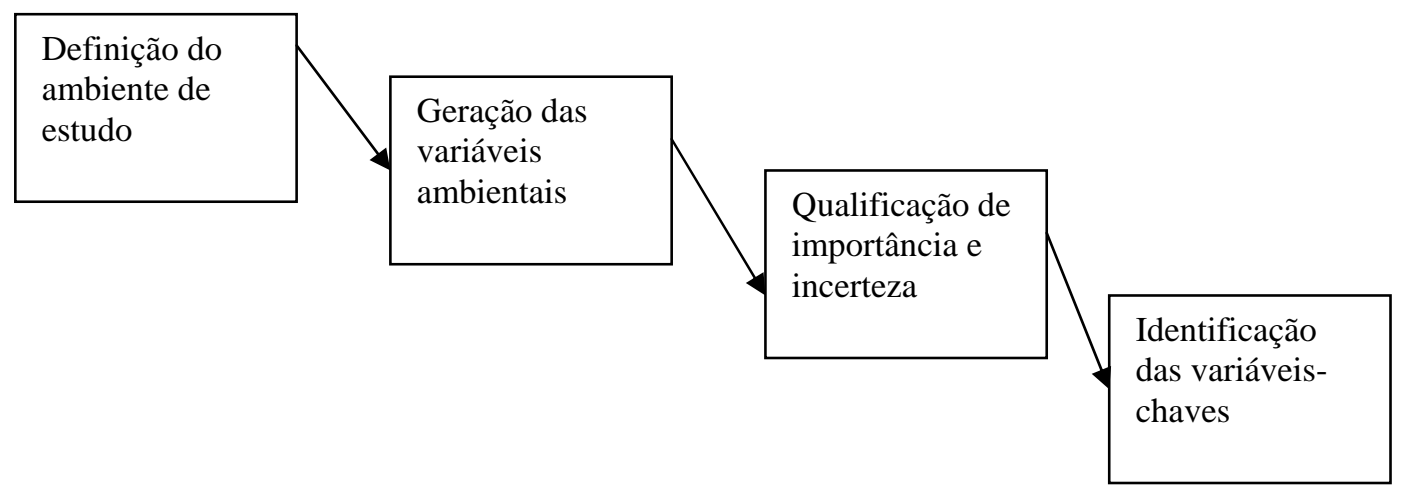

Figura 2 - Estrutura do método proposto.

FONTE: BOAVENTURA et al., 2008, pg. 91. 
As etapas para identificação das variáveis-chaves podem ser resumidas na seguinte seqüência:

1. Definição do campo de estudo;

2. Geração das variáveis ambientais;

a) Método de coleta de dados;

i. Entrevista a especialistas para enumeração de stakeholders;

1. Técnica de entrevista em profundidade;

b) Método de avaliação das variáveis - classificação;

i. Entrevista com especialistas para avaliação das variáveis;

1. Entrevista estruturada com especialistas;

3. Construir quadro de stakeholders e variáveis;

4. Qualificação de importância e incerteza;

c) Uso de escala (-5, a 5);

d) Construção de matriz de importância e incerteza;

5. Identificação das variáveis-chaves;

e) Cálculo da matriz influência-dependência;

i. Consulta aos especialistas para quantificar a influência e dependência; e

f) Construir gráfico de identificação de variáveis-chaves e tabela de orientação de roteiros dos cenários.

A definição do ambiente de estudo se dá por recorte de um objeto a ser investigado. É necessário que se defina a abrangência geográfica do estudo, o setor da economia e a indústria a que pertence e o horizonte de tempo dos cenários a serem prospectados.

A partir da definição desse objeto, é necessária a realização da identificação dos stakeholders que influenciam o ambiente no qual o objeto de estudo está inserido. As informações a respeito dos stakeholders são obtidas através da consulta aos especialistas, descrita no item 4.2.1.

Em seguida, faz-se necessário identificar as variáveis ambientais.

Os especialistas são entrevistados, tendo como base os stakeholders identificados, quando, através de entrevistas em profundidade e entrevistas estruturadas, informações coletadas dão origem às tabelas que enumeram as variáveis ambientais. 
O passo seguinte é qualificar as variáveis ambientais. Para tanto, entra no estudo a primeira análise de qualificação das variáveis ambientais, segundo sua importância e incerteza. Isso porque é através da qualificação da importância ou incerteza da influência de uma variável que se poderá definir a forma com a qual as variáveis-chaves interferirão nos futuros cenários. Mais uma rodada de questionários é realizada, na qual uma escala de importância e incerteza é aplicada.

A qualificação da importância e da incerteza se faz com a plotagem das informações em um gráfico que foi mostrado em MITROFF e EMSHOFF (1979, pg.9), Figura 3:

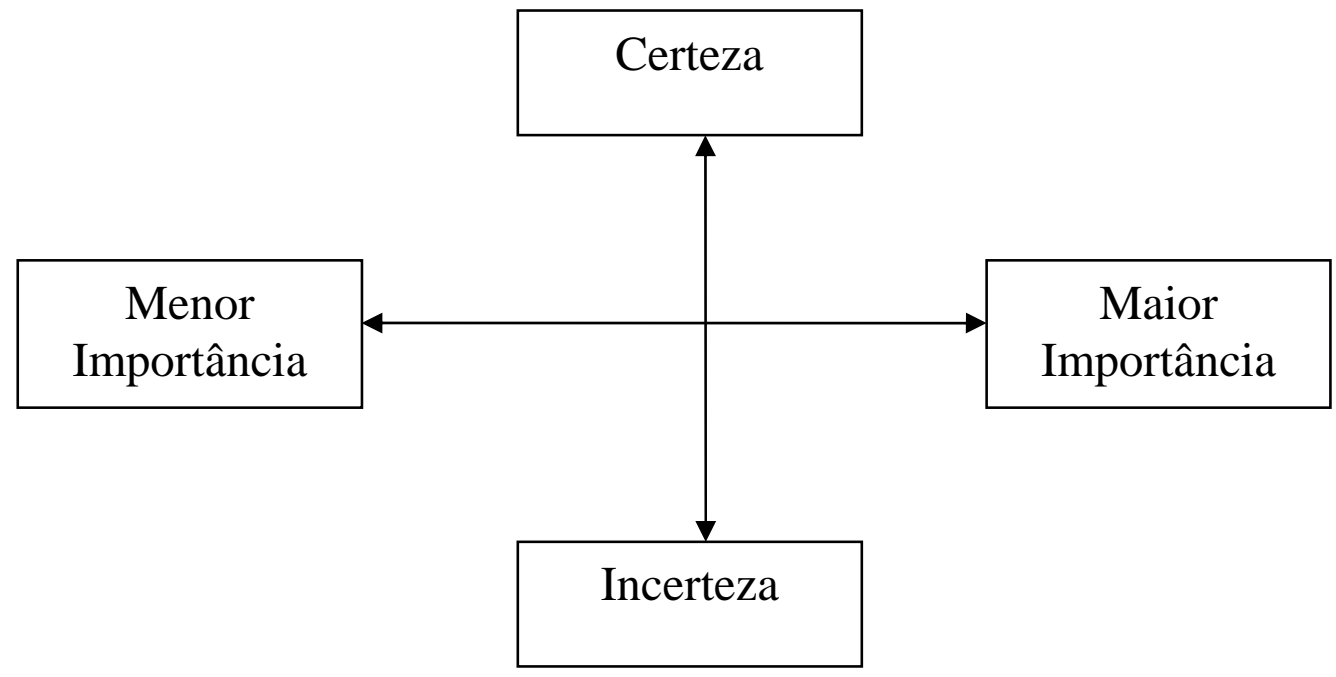

Figura 3 - Matriz de Importância e Incerteza FONTE: MITROFF e EMSHOFF, 1979, pg.9.

Depois de marcar os pontos representativos das variáveis no gráfico acima descrito, traça-se uma reta perpendicular ao eixo de importância que cruza o ponto definidor do terceiro quartil da esquerda para direita, separando os pontos descartados (à esquerda) dos pontos selecionados (à direita). Assim, determinam-se as variáveis ambientais segundo sua importância e incerteza. Então, faz-se necessário identificar quais são as variáveis-chaves do sistema.

Para identificar as variáveis-chaves do sistema são necessárias mais duas etapas. Primeiro, é preciso determinar quais são as variáveis dependentes ou influentes do 
sistema. Depois, é preciso quantificar tais características e aplicá-las em uma matriz de influência e dependência.

A identificação de variáveis influentes ou dependentes se dá pela aplicação de um questionário aos especialistas. Isso é feito através da comparação cruzada entre os pares possíveis das variáveis. Assim, especialistas são novamente consultados, desta vez sobre a influência e dependência mútua das variáveis selecionadas na etapa anterior.

Em relação ao número de outras variáveis que uma variável específica condiciona através da comparação entre pares de variáveis - são atribuídos pontos para essa variável. O mesmo se dá para características de dependência. Chega-se à etapa conclusiva da identificação. Com base nos valores obtidos e normalizados das variáveis, plotam-se os pontos numa matriz de influência e dependência. Boaventura, Costa e Fischmann (2008) utilizam em seu método uma matriz de influência e dependência proposta por Godet, conforme ilustra a figura 4:

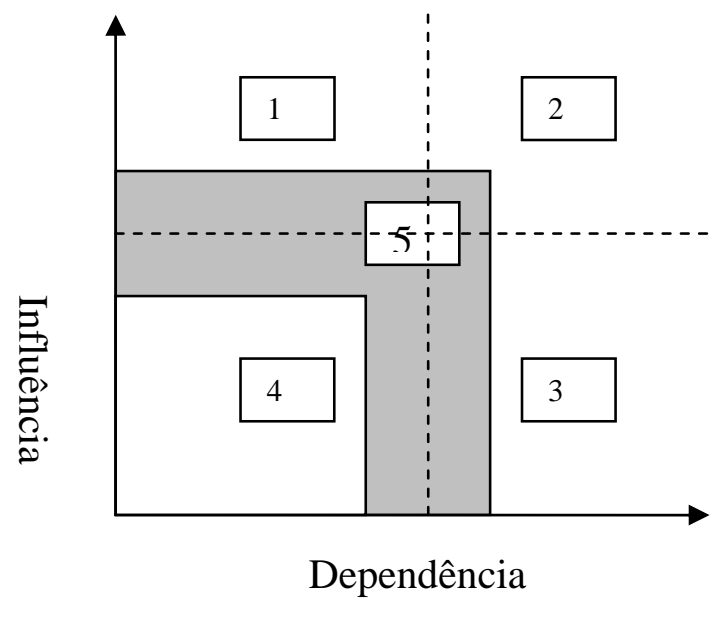

Figura 4: Gráfico Influência e Dependência FONTE: GODET, 1993, p.95.

Segundo Godet (Ibdem, pg.99), o setor 1 representa baixa dependência e alta influência, pertencendo a este setor as variáveis que condicionam o resto do sistema. O setor 2 representa as variáveis de transmissão, de grande dependência e influência, instáveis por natureza. O setor 3 representa as variáveis resultantes, de baixa influência e alta dependência, condicionadas pelos setores 1 e 2. O setor 4 representa as variáveis a 
serem excluídas por não se relacionarem com resto do sistema. O Setor 5 representa as variáveis de meio-termo, variáveis sobre as quais não se pode afirmar nada a princípio.

Depois de plotadas no gráfico de influência e dependência, finalmente as variáveischaves são identificadas e descritas cabendo ao pesquisador selecioná-las em função de dois atributos: sua alta influência no sistema e sua baixa dependência de outras variáveis, ou seja, as variáveis situadas no setor (1) do gráfico de influência e dependência. Essas variáveis darão origem a uma tabela em que se descreve o nome da variável, suas características e sua categoria (tendência ou incerteza). Com base nessa tabela os roteiros dos cenários são escritos, levando em conta tais variáveis como o esqueleto dos enredos.

As combinações de realização de tendências com a alternação do comportamento das incertezas dão origem a vários cenários. É, portanto, das combinações possíveis dessas tendências e incertezas que eles são construídos. Os critérios para escolha das combinações que darão origem aos enredos finais dependem de sua plausibilidade, originalidade e propósito de uso dos cenários esperados.

\subsection{6 - A elaboração de cenários e enredos para os cenários}

As variáveis-chaves são o cerne, o núcleo da tarefa de construção de cenários. Uma vez identificadas, o cenarista pode trabalhar com as variáveis-chaves e variáveis dependentes para matizar uma miríade de enredos para os cenários.

Schwartz e Olgivy mostram de forma sucinta dois métodos cabíveis para transformar variáveis-chaves em enredos, um com enfoque indutivo e outro com um enfoque dedutivo. No enfoque indutivo deve-se partir de perguntas diretas sobre o comportamento das variáveis-chaves para que se imaginem os eventos mais significantes para o futuro. Estimulando a criatividade, as respostas a essas perguntas diretas e desafiadoras - posto que devem questionar o comportamento das variáveischaves incertas - comporão o enredo junto com as variáveis-chaves de tendências já identificadas. Outro processo indutivo mencionado é aquele que elege um "futuro oficial" como ponto de partida. Ou seja, constrói-se um futuro considerando-se que as variáveis-chaves se comportarão tal qual se imagina no presente. Extrapolando-se o 
presente, sem rupturas ou mudanças bruscas, encontrar-se um estado futuro "previsto", "normal". Feito isso, começa-se a questionar o que poderia se desviar dessa referência futura "padrão". Daí surgem os diversos cenários prospectados. Ou seja, tal exploração dos cenários deve ser feita alternando o comportamento das variáveis incertas que compõem o "futuro ideal".

Os autores também mostram outra maneira de construir cenários e enredos, dessa vez a partir de um método dedutivo. Nesse método elegem-se duas variáveis-chaves e a partir delas deduzem-se quatro estados futuros plausíveis.

A idéia central é priorizar um par de variáveis-chaves e suas incertezas críticas referentes. As duas variáveis mais importantes são colocadas numa matriz $2 \mathrm{X} \mathrm{2}$, e abaixo delas as variáveis dependentes, dando a base para construção do enredo. Os autores enumeram algumas razões pelas quais crêem que o método dedutivo tem vantagens sobre o método indutivo:

\footnotetext{
"Existem algumas vantagens de construir cenários a partir de uma matriz. Primeiro, usando uma matriz assegura-se que os cenários serão qualitativamente diferentes do ponto de vista lógico, sem serem aleatórios. Segundo, assegura-se que as variáveis escolhidas pelos cenaristas irão ser os drivers, os motores em todos os cenários da matriz" (SCHWARTZ e OLGIVY, 1998, pg. 66).
}

Aparentemente, existe outra vantagem de se trabalhar com matrizes de variáveis-chaves. Com essa metodologia o cenarista pode tomar a "cesta" de variáveis-chaves encontradas e trabalhar pares de variáveis em diversas matrizes, conforme a necessidade das circunstâncias. Isso tende a organizar o trabalho do cenarista e evitar um erro comum e perigoso que é incluir muitas variáveis simultâneas e perder a lógica interna dos cenários visto que a complexidade aumenta exponencialmente a cada variável inclusa. Nesse caso é melhor construir cenários com menos variáveis, mas que sejam mais consistentes, do que construir cenários infinitamente complexos cuja coerência se perdeu no processo de criá-los.

A figura 5 ilustra o método hipotético para a cenarização do setor vinicultor na Califórnia empregado pelos autores: 
Variáveis selecionadas:

- Política regulatória

- Imagem do vinho e valores dos consumidores

Implicações

- Mais Lobby

- Organização dos produtores

- Monitoramento dos principais indicadores

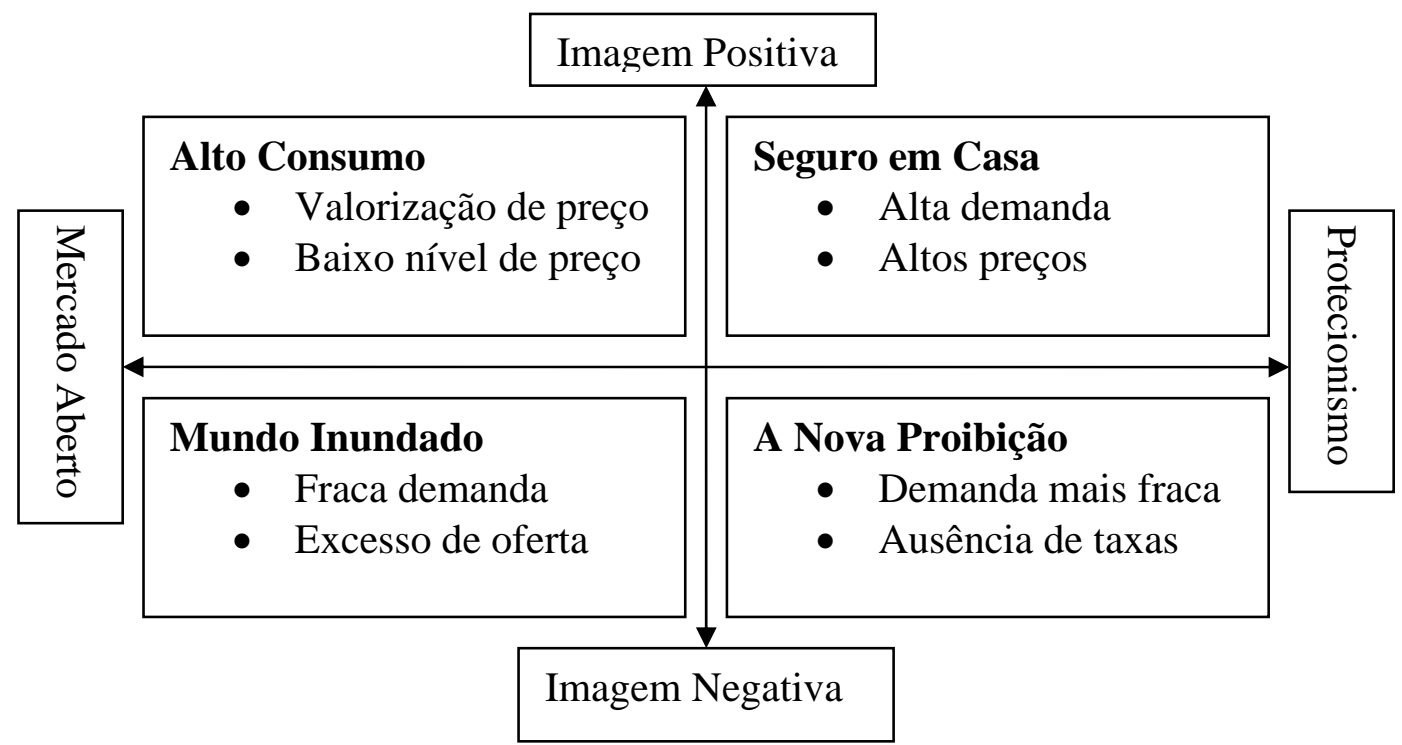

Figura 5: Futuro da Indústria de vinho na Califórnia FONTE: SCHWARTZ e OLGIVY, 1998, pag. 65

Entretanto, não basta apenas construir as matrizes. É preciso elaborar os enredos. Uma matriz como essa é apenas a base para roteirização. Embora pareça simplista trabalhar a partir de duas variáveis-chaves para criação de cenários, quando se começa a imaginar os desdobramentos dos quadrantes da matriz no tempo futuro, considerando ainda outras variáveis dependentes, nota-se a riqueza que desse método pode-se extrair.

O processo de aprofundamento nas matrizes para se fazer a roteirização segue o método do Iceberg de Peter Senge ${ }^{2}$, conforme ilustram Schwartz e Olgivy (1998. pg. 68):

\footnotetext{
${ }^{2}$ Peter Senge é especialista em aprendizagem organizacional. Propôs o modelo do Iceberg, citado por Schwartz e Olgivy. Ver: The Fifth Discipline: The art and practice of the learning organization, Doubleday, New York, 1990.
} 


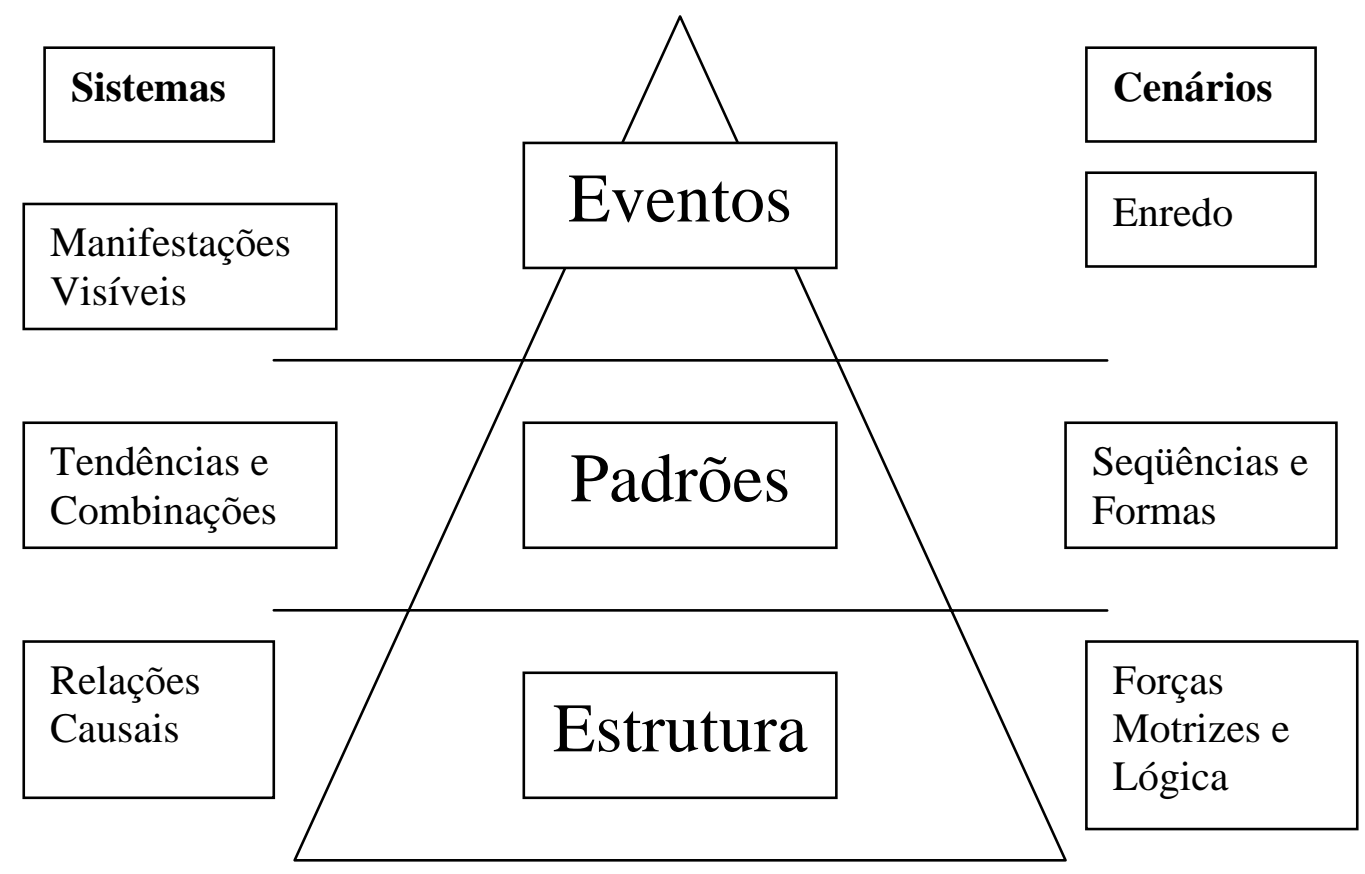

Fig 6: Modelo do Iceberg

SCHWARTZ e OLGIVY, 1998, pag. 68

As narrativas são construídas com início, meio e fim depois de identificadas as forças motrizes, os padrões de comportamento e os eventos decorrentes. As forças motrizes devem ser pensadas em termos de relações causais. As tendências e combinações dessas relações devem dar origem às seqüências e formas. As seqüências e formas originam manifestações visíveis e essas o enredo. Há uma progressão que segue a forma da pirâmide: Estrutura, padrões e eventos.

Segundo os autores, um erro comum que deve ser evitado é descrever o futuro de uma maneira estática, ou seja, como uma imagem fixa no tempo, a descrição dos eventos em uma data. Ao invés disso, deve-se descrever a sucessão dos fatos necessários para que se chegue num determinado estado futuro. Nesse aspecto, o caminho dos fatos é mais importante do que a simples descrição estática de um estado futuro. Construir uma descrição estática pode ser simplista. Relacionar essa descrição a um encadeamento lógico e plausível ao longo do tempo é o desafio do cenarista.

\subsection{7 - Aspectos contemporâneos sobre os métodos de construção de cenários}

Atualmente os métodos de construção de cenários ganharam novos escopos de análise, não apenas nas técnicas utilizadas para minerar as forças motrizes do sistema social em que formam o seu arcabouço, mas principalmente, foram aprimorados naquilo que tange 
sua consistência. Há consenso entre os intelectuais da administração e da sociologia que depois da década de oitenta as mudanças sociais tornaram-se mais turbulentas e os processos sociais com maior grau de ruptura nas suas características intrínsecas. Naturalmente, os métodos de construção de cenários evoluíram junto com essa nova configuração temporal.

Um importante aspecto na evolução dos métodos de construção de cenários foi justamente a ampliação do escopo de utilização. Ou seja, se no início os cenários tinham um caráter puramente militar, e depois da Segunda Grande Guerra ganharam sua aplicação no mundo corporativo, atualmente os métodos de construção de cenários se espalharam por áreas diversas, que vão desde os aspectos ambientais (no sentido ecológico do termo) até os cenários políticos e sociológicos.

Os cenários ganharam uma aplicação humanística e social colaborando para o enfrentamento de problemas éticos, principalmente em países do mundo em desenvolvimento onde faltam dados e estudos que embasem a tomada de decisão por parte de organismos internacionais que visam o desenvolvimento humano.

Sua aplicação sofreu uma ampliação de escopo, atendendo demandas na área de educação, saúde, saneamento básico, resolução de conflitos culturais ou territoriais além da formulação de políticas de Estado.

Os cenários, segundo essa percepção humanística estão se tornando métodos interdisciplinares, envolvendo administração, sociologia, história, matemática, economia entre outras.

Masini e Vasquez (2000, pg. 51), resumem a idéia conforme segue:

Neste sentido, os cenários permitem o estabelecimento de comunicação entre pessoas que não se entendem umas às outras, identificando atores e objetivos no sentido de compreender as raízes dos conflitos e fazer surgir de forma criativa soluções compartilhadas [...] eles constituem um exercício interdisciplinar e multicultural. 
O caráter decisório nos cenários, ou seja, seu perfil enquanto ferramenta para tomada de decisão ganhou corpo nesta década. Chermack (2004) coloca o processo de elaboração de cenários como a construção de histórias por elas próprias. Isso tem implicações importantes, principalmente na liberdade com que essas histórias se desenvolvem, liberdade essa que constitui justamente o valor criativo, a multiplicidade e o reconhecimento de aspectos não evidentes do ambiente analisado pelos tomadores de decisão das organizações.

Nesse sentido, a ciência de se fazer cenários aprimorou não somente os métodos de construção de futuros plausíveis, mas também o processo de tomada de decisão dentro das organizações. Dentro do longo processo de planejamento, para esse autor, quando se envolve um método de elaboração de cenários ocorrem quatro fenômenos interessantes ligados à tomada de decisão.

Primeiro, há a diminuição do que o autor chama de "limitação de racionalidade presa". Ou seja, as pessoas envolvidas tendem a não se prenderem aos seus modelos mentais pré-estabelecidos, dando à organização uma visão mais rica e diversa do caso estudado.

No processo de elaboração de cenários, em segundo lugar, pode-se observar uma melhor consideração sobre fatores exógenos e endógenos das variáveis que estão sendo consideradas pela organização. Isso se torna evidente visto que as variáveis prospectadas para elaboração dos cenários passam a ser consideradas por diversos especialistas, e conseqüentemente por perspectivas diferentes, dando à organização um panorama aperfeiçoado dos fatores internos e externos.

Em terceiro lugar o autor postula que há uma redução da "aderência" das informações e um melhor uso da "fricção" entre as idéias. Ou seja, as idéias ficam mais soltas nas dinâmicas de elaboração dos cenários e fluem com maior facilidade pela organização, diminuindo o "custo de comunicação" entre os especialistas. Como conseqüência ocorre uma fricção entre as idéias dos especialistas, fato salutar visto que esse atrito reduz a probabilidade de erros, conforme Chermack (2004, pg. 304) coloca:

O planejamento de cenários é uma ferramenta para redução do custo de transferência de comunicação e incremento na fricção entre conhecimentos organizacionais dos tomadores de 
decisão. Ao reduzir o custo de transferência de informação, em tese, as decisões podem ser mais eficientes e eficazes. Ao incrementar a friç̧ão entre as idéias dos tomadores de decisão, pequenos erros podem ser evitados e novas perspectivas podem ser adicionadas, que trazem outra visão e podem ser revistas. (CHERMACK, 2004, pg.304) [Trad. do autor]

Finalmente, este autor descreve como efeito da elaboração de cenários no processo decisório o fato dos cenários alterarem os modelos mentais no que tange as premissas dos tomadores de decisão. Aqui, revela-se um aspecto profundo do exercício de construção de cenários.

Mais um passo adiante na evolução dos métodos de construção de cenários pode ser visto no aumento do seu grau de sofisticação para com a validade dos resultados. Claro, se os cenários ganharam aprimoramentos conceituais no que tange sua validade decisória, é natural que se perguntasse: Mas os cenários são válidos para que se tomem decisões estratégicas sobre eles? Além de poder ser concebido como uma ferramenta de suporte à prospecção é licito perguntar em que medida os métodos de construção de cenários podem ser tidos como ferramentas à formulação decisões de escopo estratégico. Postma e Liebl (2005) tratam dessa questão partindo do pressuposto que nesse novo ambiente é comum o surgimento de paradoxos na análise ambiental durante a elaboração de cenários. Junto a tais paradoxos os autores também enunciam que "pontos cegos" na análise ambiental são encontrados.

Ora, se existem paradoxos e pontos cegos no processo de construção de cenários dada à turbulência de nosso tempo, como tornar os métodos de construção de cenários uma ferramenta de decisão estratégica, que obviamente não pode ignorar tais paradoxos e "pontos cegos" de forma leviana?

Para os autores Postma e Liebl (2005, pg.162) podem-se minimizar tais "pontos cegos e paradoxos" através de três procedimentos:

Em um primeiro procedimento sugerido trocam-se os elementos dos cenários (forças) por tendências básicas no desenvolvimento dos cenários. Convencionalmente, aglomerados de tendências são meramente representados implicitamente por alternativas de elementos valorados. Para se criarem cenários mais elucidativos poder-se-ia recombinar os aglomerados de tendências assumindo que ocorram simultaneamente. Isso traria à tona possíveis paradoxos entre as tendências estabelecidas no processo de valoração das variáveis.

Segundo, pode-se formular cenários alternativos introduzindo "wild cards", "fatores selvagens", que são pouco usuais e podem trazer um aspecto de ruptura no cenário base, livre de surpresas. 
Terceiro, [...] durante o processo de análise de impacto cruzado e análise de inconsistência, introduz-se elementos que pareçam ser de desenvolvimento paradoxal. [...] numa matriz de impacto cruzado ou de consistência que indicam baixa probabilidade/alta inconsistência são mudadas em alta probabilidade/alta consistência, respectivamente ${ }^{3}$. [Trad. do Autor]

Com esses procedimentos, o cenarista pode lidar de forma mais adequada com a turbulência e os paradoxos da sua análise, o que é imprescindível para tornar um método de construção de cenários num modelo de apoio à decisão estratégica no início século XXI.

Outra questão fundamental sobre a validade da construção de cenários reside na análise de sua consistência, ou seja, passou-se a testar a consistência dos resultados como um todo. Boaventura e Fischmann propuseram isso no artigo "Is your vision consistent? A method for checking, based on scenario concepts.", publicado na revista Futures em 2008.

A primeira conceituação que o artigo traz está na idéia de visão, que congrega tanto a configuração futura desejada pela organização quanto para o ambiente externo. Da articulação entre tais aspectos surge uma visão de futuro. Dentro dessa análise encontram-se tendências e incertezas e forças motrizes que condicionam o presente. Tais forças são de naturezas diversas, sendo que algumas são variáveis-chaves, ou seja, são variáveis que condicionam o sistema.

A partir da amplitude das incertezas e tendências cria-se uma zona de cenários possíveis, sendo que um cenário é um ponto ao longo dessa área de possibilidades. Entretanto, nem todos os cenários são plausíveis ou desejáveis. De fato, há uma sobreposição de três conjuntos de resultados. Os cenários desejados, os cenários plausíveis e os cenários possíveis.

\footnotetext{
${ }^{3}$ Na construção de cenários para o futuro do clima seriam inseridas variáveis paradoxais. Algumas variáveis tidas como improváveis são tratadas como sendo prováveis para gerar cenários mais ricos. Um exemplo poderia ser descrito da seguinte forma: Em um cenário sobre o clima do planeta poderia-se assumir contra a probabilidade dos acontecimentos o aumento da cobertura vegetal do planeta, ao invéz de sua diminuição. Isso traria cenários mais diversos.
} 


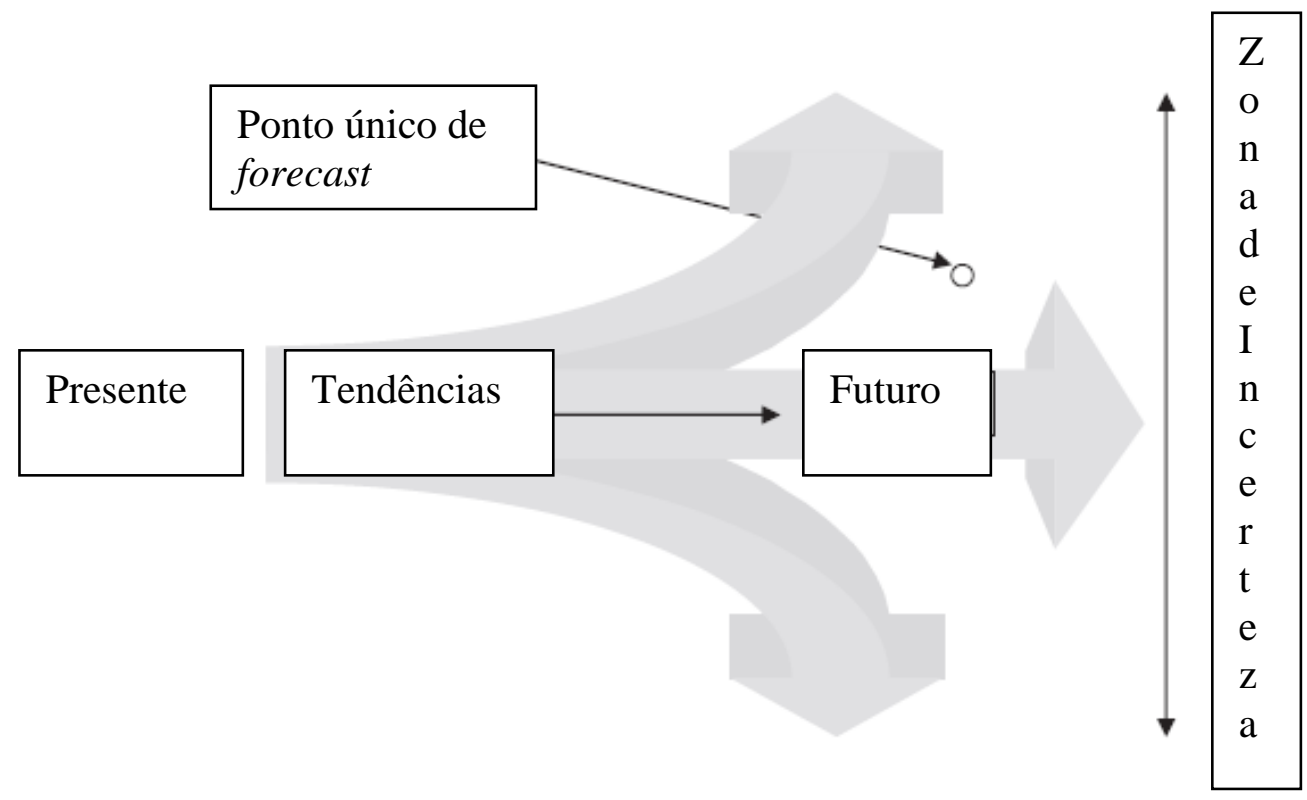

Figura 7 - Zona de incerteza

Fonte: BOAVENTURA, 2008, Pg.600

O método proposto visa analisar dois aspectos. Checar o conteúdo dos cenários, relacionando as variáveis-chaves à visão de futuro de uma organização que participa desse ambiente e a consistência da relação entre essas variáveis em uma matriz que avalia a possibilidade de coexistência entre elas. São testadas as incongruências e consistência das asserções com fim de validar os cenários construídos.

O artigo "Is your vision consistent?" (Boaventura e Fischman, 2008) traz uma aplicação prática dessa ferramenta de análise de consistência feita no setor de automação comercial, e conclui que o método é operacionalmente viável. 


\section{O ETANOL DE SEGUNDA GERAÇÃO}

\subsection{Biocombustíveis no Brasil}

O uso de fontes renováveis de energia nos remonta ao controle pleno do fogo pelo homo ergaster no pleistoceno médio. A dendroenergia (lenha) foi a primeira fonte de energia armazenável usada pela humanidade. Posteriormente, os óleos vegetais e o álcool foram descobertos e usados por diversas culturas há mais de cinqüenta séculos. As fontes energéticas renováveis geraram luz e calor, cozeram alimentos, serviram de base para atividades metalúrgicas e processos produtivos pré-industriais por milhares de anos. Entretanto, seu uso foi majoritariamente substituído a partir do século XVIII nas civilizações industriais por fontes energéticas fósseis. Isso se deu de forma mais acentuada após a invenção dos motores à combustão. Nos séculos subseqüentes aumentou-se o consumo de fontes fósseis de energia de forma exponencial e, atualmente, os combustíveis fósseis são os combustíveis mais largamente empregados por nossa civilização (LEITE 2005, pg. 15).

Entretanto, nos últimos trinta anos, o uso dos combustíveis fósseis passou a ser questionado pela comunidade científica por estar ligado a problemas de escassez, ambientais e geopolíticos. Nesse contexto, os combustíveis renováveis ganharam uma nova dimensão de utilidade e passou-se a considerar novamente a sua adoção, desta vez como matriz energética em sociedades industriais (SACHS, 2005).

Tal releitura dos combustíveis renováveis como fonte energética de larga escala para uso em sociedades industrializadas possui um notório exemplo, observável no caso brasileiro. Nas décadas de setenta e oitenta o Brasil sofreu com as duas crises do petróleo, na medida em que os preços do barril subiram mais de 300\%. O Brasil era forte importador de petróleo e tal aumento ocasionou um rombo na balança de pagamentos nacional. Dadas as condições geográficas serem favoráveis para se produzir cana-de-açúcar, insumo primário da produção nacional de etanol, o governo brasileiro, frente aos choques do petróleo, vislumbrou a possibilidade de se produzir etanol, principalmente no interior de São Paulo, para substituir a gasolina por álcool sob a forma de combustível veicular (JOSEF, 2007). 
O programa paulista de biomassa se tornou o maior programa de energia renovável do mundo (em jaules de energia produzida). A conquista dessa magnitude no uso da energia renovável foi fruto da liderança brasileira na tecnologia de primeira geração de produção de etanol (tecnologia tradicional de fermentação do caldo da cana-de-açúcar) GOLDENBERG (2007, pg.28).

Entretanto, com o avanço da ciência, criaram-se as tecnologias de segunda geração na produção de etanol, conforme ilustra a passagem abaixo:

A abrangência do avanço científico, particularmente nas ciências da vida durante os últimos cinqüenta anos foi extraordinária. Essa acumulação de conhecimento biológico gerou novas tecnologias e estimularam várias antigas tecnologias de base biológica. [Trad. do autor] (THOMPSON, 1986, pg. 514)

As tecnologias de segunda geração para produção de etanol são o caso de antigas tecnologias tradicionais estimuladas pelo avanço biotecnológico dos últimos anos. A hidrólise enzimática é uma dessas tecnologias. Com o uso dela não se fermentam os açúcares simples contidos no caldo da cana-de-açúcar, mas se transforma a madeira (celulose) da planta em açúcares simples para posterior fermentação e produção de etanol. Como foi dito, a hidrólise da celulose é uma das tecnologias de produção de etanol de segunda geração. Hidrolisar a celulose significa quebrar a estrutura molecular do bagaço da cana-de-açúcar em açúcares simples, em outras palavras, transformar “a madeira da planta” em açúcares solúveis e passíveis de se transformarem em etanol pela ação de microrganismos.

\subsection{Aspectos técnicos do etanol de segunda geração}

Segundo GOLDENBERG (Op. cit., pg.26), no processo de crescimento da cana-deaçúcar, o vegetal usa a energia solar para manutenção de seus processos fisiológicos. Entre esses processos, está o de síntese da celulose, que é a biomassa estrutural dos vegetais. Ela é encontrada principalmente na parede celular dos vegetais. A celulose é composta de moléculas de glicose. Para produzir celulose, o vegetal precisa, entre uma variedade de compostos químicos complexos, sintetizar as moléculas de glicose que a constituirão. A glicose, por sua vez, é sintetizada a partir da fotossíntese. 
A fotossíntese pode ser entendida como o conjunto de reações que combinam o $\mathrm{CO}_{2}$ da atmosfera ao $\mathrm{H}_{2} \mathrm{O}$ utilizando-se para reação a energia da luz solar. Como resultado forma-se a molécula da glicose (de alto conteúdo energético) e moléculas de oxigênio que são liberadas na atmosfera. A reação pode ser representada de forma simplificada da seguinte forma:

$$
\mathrm{CO}_{2}+\mathrm{H}_{2} \mathrm{O}>>\left(\text { luz) }>>\mathrm{C}_{12} \mathrm{H}_{2} \mathrm{O}_{6} \text { (glicose) }+\mathrm{O}_{2}\right.
$$

No caso da cana-de-açúcar, 1/3 da glicose produzida é disponibilizada na seiva do vegetal (caldo) e 2/3 são usados para síntese da celulose (1/3 no bagaço + 1/3 nas palhas e pontas). A celulose é um polissacarídeo formado, entre outros compostos, por 10.000 moléculas de glicose ligadas. Portanto, a maior parte da glicose sintetizada pelo vegetal é fixada na forma de celulose, conforme mostra a figura 8:

\section{CELULOSE}

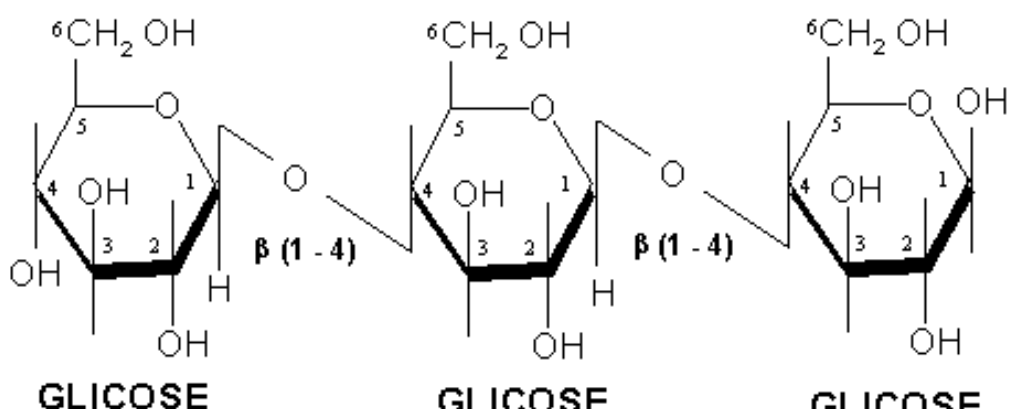

Fig. 8 - Polímero da Celulose

Fonte: GOLDENBERG, 2008, pg.27.

A hidrólise enzimática é o processo bioquímico que quebra a celulose em moléculas de glicose. A hidrólise da celulose pode ser realizada de várias formas, a saber, a rota enzimática, a rota ácida e a rota alcalina. Este estudo optou por investigar a hidrólise enzimática pelo fato da rota enzimática ser a mais estudada atualmente e ser a de menor impacto ambiental. Na hidrólise enzimática a celulose é quebrada por enzimas, compostos bioquímicos complexos que agem como "tesouras químicas", cortando macromoléculas em moléculas simples (BUCKERIDGE, 2009) e (ZACCHI, 2009). 
A hidrólise já é dominada em escala laboratorial, ou seja, já se produz etanol a partir de celulose em laboratórios de diversos países do mundo, inclusive no Brasil. Dominar a tecnologia da produção de etanol de segunda geração é fundamental para se manter competitivo no setor de energia renovável, em particular no de biocombustíveis.

O governo brasileiro investe maciçamente no desenvolvimento da hidrólise, particularmente nos laboratórios de universidades públicas. E o vem fazendo com mais vigor nos últimos anos, dada à importância dessa tecnologia. Existem fatos que mostram que a tecnologia da hidrólise está se tornando, a cada dia, mais próxima da escala industrial. Um deles é a construção de uma planta piloto para converter celulose em etanol em escalas semi-industriais (ROSSEL et.al, 2008, pg.29).

A migração da produção de etanol de segunda geração da escala laboratorial para a escala industrial pode aumentar a produtividade das usinas de etanol significativamente. Entretanto, mesmo considerando um desenvolvimento de tamanha importância, não se encontrou publicações de cenários sobre o futuro do setor tendo em vista o etanol de segunda geração. Há sim muita pesquisa técnica sobre o assunto nas áreas das ciências naturais, mas, pouca coisa se escreveu sobre cenários prospectivos nessa área.

Foi publicado um artigo na Biomass Bioenergy, intitulado "Projected mature technology scenarios for convertion of cellulosic biomass to ethanol with co-prodution of themochemical fuel, power and/or animal feed protein" (LASER, et al., 2008), que mostra os cenários da produção de etanol para a maturidade da tecnologia da hidrólise enzimática em conjunto com a geração de energia e fabricação de ração animal, todavia, esse artigo não se aplica à realidade brasileira por não tratar especificamente da produção de etanol a partir da cana-de-açúcar. 


\section{PROCEDIMENTOS METODOLÓGICOS}

\subsection{Caracterização de Pesquisa}

Este trabalho caracteriza-se como uma pesquisa científica desenvolvida no campo das ciências sociais aplicadas, especificamente no campo da administração geral. É uma pesquisa exploratória, de caráter observacional, cujo objetivo é construir cenários para setor produtivo de etanol.

\subsection{Métodos de Pesquisa}

Os métodos das ciências sociais contribuem para a sistematização e formalização da pesquisa, tornando o conhecimento gerado compartilhável. GIL (1999, pg. 34) ressalta que os principais métodos de pesquisa científica são:

a) Método Experimental - Submete-se o objeto à determinadas variáveis controladas e observa-se os resultados da interação entre o objeto e as variáveis;

b) Método Observacional - Comum nas ciências sociais, consiste em observar os efeitos já ocorridos de variáveis que influenciaram de alguma maneira um objeto social;

c) Método Estatístico - É um método de apoio que utiliza da estatística para auxílio da investigação, possibilitando muitas vezes a generalização das descobertas em uma amostra para o universo de pesquisa com determinado grau de confiança;

d) Método Clínico - É um método intersubjetivo, onde pesquisador e pesquisado estabelecem uma teia de significados simbólicos a fim de chegar a conclusões sobre o estado do pesquisado; e

e) Método Comparativo - É a investigação de fenômenos entre objetos onde se observa similaridades e diferenças entre eles, buscando-se simplesmente a descrição ou, em um grau mais elaborado as razões de se apresentarem tais semelhanças e diferenças.

O método adotado nessa pesquisa é o observacional visto que irá se aplicar um método de investigação em um conjunto de especialistas a fim de obter os cenários futuros para 
o setor produtivo de etanol tendo em vista o etanol celulósico como fator relevante nos próximos dez anos.

\subsubsection{Consulta aos especialistas}

A consulta a especialistas é uma técnica de coleta de dados que se utiliza da entrevista (estruturada, semi-estruturada ou em profundidade), a fim de que se obtenha as informações necessárias para a pesquisa. Consiste em um encontro com os investigados para que se dirijam perguntas a eles e se coletem as respostas. Vale notar que a consulta precisa ser feita com indivíduos que tenham conhecimento especial em relação ao objeto de estudo. A idéia de especialista na pesquisa de administração se assemelha à idéia de informante-chave da antropologia, que pode informar sobre detalhes históricos e culturais do seu ambiente (FETTERMAN, 1998, pg. 483).

Nessa pesquisa, a consulta a especialistas ocorrerá em três etapas, conforme requisita o método a ser aplicado e ilustra Boaventura (2003, pg.9):

1. Consulta a especialistas para identificação das variáveis-chaves;

2. Consulta a especialistas para classificar as variáveis-chaves em tedências e incertezas; e

3. Consulta a especialistas para ordenar as tendências e incertezas segundo sua importância e dependências e respectiva eleição de variáveis-chaves.

4. Elaboração dos cenários segundo método descrito no ítem 2.2.6

\subsection{Universo e Amostra}

O conceito de amostra pode ser definido como um subconjunto do universo da população que representa qualitativamente e ou quantitativamente esse universo com um certo grau de confiança. Entretanto, existe uma miríade tipológica de amostras, que são constituídas a partir das características da pesquisa e do universo. Os tipos de amostras encontrados na literatura são basicamente oito. Amostragem sistemática, estratificada, por conglomerados, por etapas, por acessibilidade ou conveniência, por tipicidade ou intencional e por cotas. Para esse estudo, será construída uma amostragem por tipicidade. A amostra por 
tipicidade ou intencional pode ser definida conforme Gil (Op. cit., pg104) demonstra:

"[...] Um tipo de amostragem não probabilística que consiste em selecionar um subgrupo da população que, com base nas informações disponíveis, possa ser considerado representativo de toda população. [...] Entretanto, requer considerável conhecimento da população e do subgrupo selecionado."

O universo a ser estudado é o conjunto de organizações ligadas ao setor produtivo de etanol que estejam trabalhando para o desenvolvimento técnológico, político ou econômico do etanol de segunda geração com sede ou representação física no Estado de São Paulo.

Os quinze tipos de organizações selecionadas que se mostram relevantes para o futuro das usinas em relação ao etanol de segunda geração são:

1. Centro de tecnologia

2. Universidades

3. Órgão de fomento de pesquisa

4. Usina de etanol

5. Entidade de classe da indústria da cana

6. Fabricante de insumos

7. Governo

8. Fabricante de equipamentos

9. Imprensa especializada

10. Empresa de consultoria em financiamento

11. Empresa de consultoria em Engenharia

12. Centro de pesquisas econômicas

13. Instituição financeira

14. Empresa pública do setor sucroenergético

15. Órgãos de Patentes 


\subsection{Coleta de Dados e Instrumento de Coleta}

Para levantar os dados junto aos especialistas foram elaborados três questionários. Os questionários foram adaptados em Boaventura (Op. cit., pg. 142) e estão no ANEXO 3 deste trabalho.

\subsection{Modelo conceitual-teórico da pesquisa}

O modelo conceitual-teórico é apresentado na figura 9:

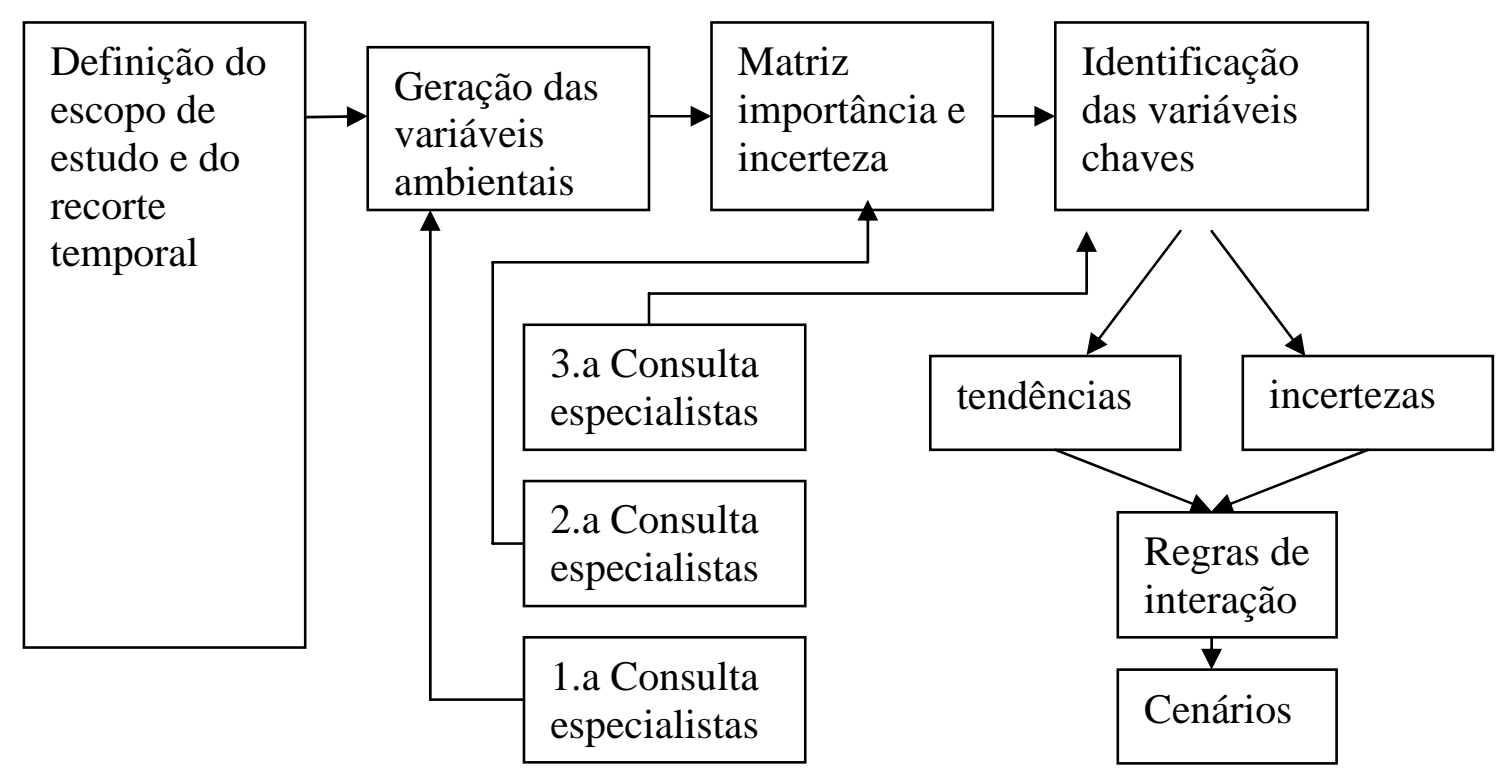

Figura 9 - Modelo conceitual-teórico da pesquisa

\subsection{Limitações da Pesquisa}

Essa pesquisa tem por objetivo aplicar um método de geração de variáveis-chaves e construir cenários a partir de um método pré estabelecido. A limitação na utilização desse método está no fato de se gerar cenários ambientais de primeira geração, sem que haja a pretensão de se propor estratégias a partir dos mesmos.

Outra limitação dessa pesquisa reside no fato dela se focar exclusivamente no desenvolvimento de cenários que contemplem o etanol de segunda geração oriundo da hidrólise enzimática, descartando todos os outros processos de obtenção do etanol de segunda geração. 
A pesquisa limitou-se geograficamente ao Estado de São Paulo, e temporalmente a um horizonte de dez anos. 


\section{CONSULTA AOS ESPECIALISTAS}

A construção de cenários através do método proposto pressupõe três etapas de consulta aos especialistas. É através das consultas aos especialistas que se obtiveram os dados necessários para a construção dos cenários. Trata-se de uma pesquisa de campo cuja finalidade é elaborar uma análise ambiental sobre a questão do etanol de segunda geração. Foram realizadas três rodadas de coleta dos dados, conforme descrito no ítem 4.2.1, "Consulta aos Especialistas".

O método empregado consistiu de entrevistas em profundidade e estruturadas, onde houve um roteiro a ser seguido. Na primeira etapa da consulta aos especialistas o roteiro de entrevistas possuía questões pré-definidas e questões que propiciavam maior liberdade para o entrevistado discorrer sobre o tema. Nas etapas posteriores tratou-se de aplicar questões objetivas, com uso de escalas e quantificadores numéricos.

A consulta foi feita com uma gama de especialistas ligados ao problema da pesquisa e abrangeu engenheiros, cientistas, administradores, políticos, jornalistas, enfim, toda uma gama de profissionais que representasse os stakeholders ligados ao problema. A idéia principal foi consultar indivíduos informados sobre as necessidades e características de uma comunidade específica, no caso, o setor produtivo de etanol. A consulta a especialistas mostra-se particularmente interessante por ser de processamento simples, e extremamente útil ao se tratar de problemas específicos e pouco comuns.

\subsection{Etapas da coleta de dados}

O objetivo da coleta de dados é desvelar as variáveis do ambiente estudado em vista do problema proposto, qualificar essas variáveis e compará-las, de forma que ao final do processo se consiga eleger quais variáveis são fundamentais para construção dos cenários.

As variáveis são primeiramente identificadas nas entrevistas com os especialistas, em seguida são qualificadas quanto à importância e à incerteza. Finalmente, as variáveis são comparadas quanto à sua influência e dependência. Ao descobrir quais são as variáveischaves do sistema, a tarefa de elaboração dos cenários pôde ser empreendida. 


\subsection{Delimitação do ambiente}

O ambiente de estudo deste trabalho se restringe ao setor produtivo de etanol do Estado de São Paulo.

Através das entidades de classe da indústria da cana-de-açúcar chegou-se a uma relação de cento e onze usinas no Estado de São Paulo. Para esse estudo escolheu-se trabalhar com uma dessas usinas e demais stakeholders do setor.

A lista das usinas associadas à UNICA - União da Indústria da cana-de-açúcar e/ou à Copersucar - Cooperativa de Produtores de Cana-de-açúcar encontram-se no ANEXO I.

\subsection{Perfil dos especialistas}

A escolha dos especialistas foi feita em função de dois critérios. Primeiramente ao fato do especialista estar ligado a uma organização relevante no quadro de stakeholders das usinas de produção de etanol. Em segundo lugar, ter experiência e conhecimento específico sobre a questão do etanol de segunda geração.

O perfil dos especialistas consultados segue abaixo:

1 - Diretor de empresa de consultoria financeira

2 - Professor e pesquisador vinculado à universidade pública

3 - Gerente técnico de centro de pesquisa de etanol

4 - Presidente de indústria fabricante de insumos

5 - Consultor de entidade de classe da indústria da cana-de-açúcar

6 - Gerente de produção de usina de etanol

7 - Assessor do programa de etanol do Governo do Estado de São Paulo

8 - Gerente técnico de empresa fabricante de equipamentos

9 - Editor de tecnologia de revista especializada

10 - Diretor do programa de bioenergia de órgão de fomento à pesquisa

Por questões de disponibilidade e conveniência, durante as diferentes etapas da coleta de dados ocorreram consultas a especialistas substitutos com as mesmas capacidades 
técnicas daqueles consultados nas fases anteriores, conforme descrito na lista de especialistas consultados. Vide ANEXO 2.

\subsection{Primeira fase da coleta de dados}

Seguem as etapas necessárias para identificação dos stakeholders e as variáveis que interferem no sistema estudado.

\subsubsection{Identificação das variáveis do ambiente}

O objetivo dessa etapa na coleta dos dados é identificar quais são as variáveis que influenciam o ambiente estudado. Não há, nessa etapa, qualquer preocupação quanto à qualificação ou quantificação dessas variáveis. Entretanto, descobrí-las é um aspecto fundamental. Foram entrevistasdos os especialistas em relação aos stakeholders e seguindo a metodologia utilizada, as variáveis foram identificadas.

O questionário empregado (ANEXO 3) sugeriu uma lista básica de stakeholders e elaborou uma série de questões para que o especialista informasse o pesquisador sobre as variáveis que estavam envolvidas na atuação dos mesmos. Havia a liberdade de acrescentar novos stakeholders caso se julgasse necessário.

Lista de stakeholders elencados:

1. Centro de tecnologia

2. Universidades

3. Órgão de fomento de pesquisa

4. Usina de etanol

5. Entidade de classe da indústria da cana

6. Fabricante de insumos

7. Governo

8. Fabricante de equipamentos

9. Imprensa especializada

10. Empresa de consultoria em financiamento 
11. Empresa de consultoria em Engenharia

12. Centro de pesquisas econômicas

13. Instituição financeira

14. Empresa pública do setor sucroenergético

15. Órgãos de Patentes

Stakeholders acrescentados durante a coleta na fase I:

16. Montadoras; e,

17. Empresa privada de pesquisa tecnológica.

Ao todo os especialistas levantaram 87 variáveis que interferem no sistema estudado. Diversos especialistas identificaram variáveis semelhantes. Nesses casos as variáveis foram unificadas em uma mesma terminologia. Foram assim obtidas 59 variáveis válidas das 87 originais. O processo de unificação e retificação das variáveis de cada Stakeholder está decrito detalhadamente no ANEXO 4.

A média de variáveis por especialista foi de 32,4 variáveis ao passo que o total de variáveis operacionais chegou a 59. Atribui-se essa diferença à diversidade de especialistas consultados, fator que enriqueceu a análise ambiental.

\subsubsection{Descrição dos stakeholders e principais variáveis}

A relação de stakeholders citados por especialista pode ser observado abaixo. O quadro 4 aponta os stakeholders nomeados por cada especialista consultado na primeira etapa da coleta de dados. 
Quadro 4 - Stakeholders citados por especialistas

\begin{tabular}{|c|c|c|c|c|c|c|c|c|c|c|}
\hline \multirow[t]{2}{*}{ Stakeholders } & \multicolumn{10}{|c|}{ Especialistas } \\
\hline & 1 & 2 & 3 & 4 & 5 & 6 & 7 & 8 & 9 & 10 \\
\hline Centro de tecnologia & & $\mathbf{x}$ & $\mathbf{x}$ & $\mathbf{x}$ & $\mathbf{x}$ & $\mathbf{x}$ & & $\mathbf{x}$ & $\mathbf{x}$ & $\mathbf{x}$ \\
\hline Universidades & & $\mathbf{x}$ & $\mathbf{x}$ & $\mathbf{x}$ & $\mathbf{x}$ & & & $\mathbf{x}$ & $\mathbf{x}$ & $\mathbf{x}$ \\
\hline Órgão de fomento de pesquisa & & & $\mathbf{x}$ & $\mathbf{x}$ & & & & & $\mathbf{x}$ & $\mathbf{x}$ \\
\hline Usina de etanol & & $\mathbf{x}$ & $\mathbf{x}$ & $\mathbf{x}$ & & $\mathbf{x}$ & & $\mathbf{x}$ & $\mathbf{x}$ & $\mathbf{x}$ \\
\hline Entidade de classe da indústria da cana & & $\mathbf{x}$ & $\mathbf{x}$ & $\mathbf{x}$ & $\mathbf{x}$ & $\mathbf{x}$ & $\mathbf{x}$ & $\mathbf{x}$ & $\mathbf{x}$ & $\mathbf{x}$ \\
\hline Fabricante de insumos & $\mathbf{x}$ & $\mathbf{x}$ & $\mathbf{x}$ & & $\mathbf{x}$ & $\mathbf{x}$ & $\mathbf{x}$ & $\mathbf{x}$ & $\mathbf{x}$ & $\mathbf{x}$ \\
\hline Governo & $\mathbf{x}$ & $\mathbf{x}$ & & & $\mathbf{x}$ & $\mathbf{x}$ & & $\mathbf{x}$ & & $\mathbf{x}$ \\
\hline Fabricante de equipamentos & $\mathbf{x}$ & & & & & & & & & \\
\hline Imprensa especializada & $\mathbf{x}$ & & & & & & & & $\mathbf{x}$ & \\
\hline Empresa de consultoria em financiamento & $\mathbf{x}$ & & & & $\mathbf{x}$ & & & & & \\
\hline Empresa de consultoria em engenharia & $\mathbf{x}$ & & & & & & & & & \\
\hline Centro de pesquisas econômicas & $\mathbf{x}$ & $\mathbf{x}$ & & & $\mathbf{x}$ & $\mathbf{x}$ & & $\mathbf{x}$ & & \\
\hline Instituição financeira & $\mathbf{x}$ & & $\mathbf{x}$ & $\mathbf{x}$ & $\mathbf{x}$ & $\mathbf{x}$ & $\mathbf{x}$ & & $\mathbf{x}$ & $\mathbf{x}$ \\
\hline Empresa pública do setor sucroenergético & & $\mathbf{x}$ & $\mathbf{x}$ & & $\mathbf{x}$ & & & $\mathbf{x}$ & $\mathbf{x}$ & $\mathbf{x}$ \\
\hline Órgão de Patente & & & & & & & & $\mathbf{x}$ & $\mathbf{x}$ & \\
\hline Montadoras de automóveis & & & $\mathbf{x}$ & & & & & & $\mathbf{x}$ & \\
\hline Empresa privada de pesquisa tecnológica & & & & $\mathbf{x}$ & & & & & $\mathbf{x}$ & \\
\hline
\end{tabular}

\subsubsection{Análise dos stakeholders e variáveis levantadas}

\section{1) Centro de Tecnologia}

Os centros de tecnologia exercem um papel relevante no setor de biocombustíveis. Viade-regra eles são planejados e construídos através de iniciativas governamentais e contam com financiamento público e privado na condução de seus trabalhos. É neles que há uma maior interação entre a pesquisa pública e a pesquisa privada. Estão também ligados às universidades públicas visto que elas abrigam suas instalações e fornecem o quadro técnico altamente especializado que os compõem. Os centros de pesquisa fazem a “ponte” entre as necessidades da indústria e o desenvolvimento tecnológico. A pesquisa básica muitas vezes está concentrada em institutos científicos puramente acadêmicos cabendo aos centros de tecnologia intermediar o processo de migração da ciência básica (academia) para a aplicação tecnológica (indústria).

As questões técnicas pesquisadas por esses centros estão diretamente ligadas aos desafios das indústrias. Durante a entrevista destacaram-se a importância da pesquisa 
nos gargalos técnicos para o aumento da eficiência produtiva do etanol de segunda geração assim como na elaboração de softwares para simular rotas químicas experimentais. O aumento da eficiência dos microrganismos tanto para a produção de enzimas como para a fermentação dos açúcares, a questão do pré-tratamento do bagaço, a elaboração de coquetéis enzimáticos propícios para as etapas da hidrólise enzimática foram os gargalos técnicos mais importantes destacados.

\section{2) Universidades}

As universidades possuem o importante papel de formar recursos humanos altamente especializados para a evolução tecno-econômica do setor produtivo de etanol. Forma e abastece de pesquisadores e profissionais de todas as áreas as mais diversas organizações que compõem o setor. Em relação à pesquisa desenvolve o importante papel de financiar a pesquisa básica, criar centros de pesquisa e integrar a pesquisa brasileira à pesquisa de universidades internacionais, conferindo à pesquisa brasileira um padrão de classe mundial no campo da bioenergia. Essas duas características são fundamentais para que o etanol de segunda geração migre da escala laboratorial e ganhe escala industrial de produção.

3) Órgão de fomento à pesquisa

Os órgãos de fomento à pesquisa são instituições autônomas financiadas prioritariamente com verba pública federal ou estadual. Desempenham um importante mecanismo de financiamento de pesquisa nas universidades e centros de tecnologia. Se por um lado as universidades apóiam os pesquisadores com infra-estrutura e suporte acadêmico, os órgãos de fomento financiam os projetos dos próprios pesquisadores. A seleção dos projetos que serão financiados deve atender às requisições técnicas do órgão de fomento assim como as necessidades apontadas em suas políticas de desenvolvimento científico.

No caso dos biocombustíveis de segunda geração, há uma grande concentração de institutos com linhas de pesquisa diversas, cabendo aos órgãos de fomento avaliar o que está sendo pesquisado, o que está se propondo pesquisar e o que precisa ser pesquisado a fim de se concatenar demandas frente a um orçamento destinado àquela área 
científica. As variáveis brutas desse stakeholder mostraram algumas questões técnicas importantes que podem ser entendidas como gargalos tecnológicos para o desenvolvimento da tecnologia. A pesquisa genética também se mostrou como uma poderosa variável para o futuro do etanol de segunda geração.

4) Usina de etanol

As usinas de etanol são indústrias que processam a cana-de-açúcar para produção de etanol, valendo-se do processo de produção de primeira geração. Além do etanol de primeira geração algumas delas produzem açúcar e geram energia elétrica com a queima do bagaço e da palha.

Não existe nenhuma usina de etanol produzindo etanol de segunda geração em escala comercial, entretanto há uma expectativa positiva sobre a implementação dessa tecnologia, visto que quando se produz etanol a partir do bagaço surge a possibilidade de se produzir etanol e açúcar simultaneamente. Essa possibilidade flexibilizaria a produção e potencialmente reduziria o risco da operação. Vale notar que a produção simultânea de etanol (do bagaço), açúcar (da seiva), bioplástico (do etanol), bioeletricidade (da palha), ração animal (do bagaço hidrolizado) e metano (a partir do vinhoto) constituem a ampla diversificação no futuro do setor. Essa flexibilização é a mola propulsora que visa integrar nas usinas a operação de primeira geração com a segunda geração.

Outros fatores são importantes nesse sentido, como a modernização do parque industrial do etanol de segunda geração, eletrificando e automatizando processos, além da importante mecanização da fase agrícola. Com a mecanização da fase agrícola deixa-se de queimar a palha para a realização da colheita manual e passa-se a usar a palha como cobertura para o solo, ou ainda, para que se queime-a nas usinas a fim de gerar eletricidade. Nota-se que para ser possível flexibilizar a produção é preciso que se mecanize o campo. 
5) Entidades de classe da indústria da cana

As entidades que representam a indústria da cana-de-açúcar mostraram ter uma atuação política fundamental no setor. Primeiramente, como catalisadoras na abertura de novos mercados para o etanol brasileiro de primeira geração, e conseqüentemente, a abertura de mercado para a futura produção de etanol de segunda geração. No tocante ao desenvolvimento tecnológico, as entidades de classe da indústria da cana facilitam o desenvolvimento tecnológico do setor. Promovem congressos e reuniões que visam integrar os stakeholders orientando as estratégias de investimentos gerais dos produtores.

6) Fabricante de Insumos

Esse stakeholder é composto por um conjunto de empresas diversas que fornecem insumos supérfluos para produção de etanol de segunda geração e um insumo crítico. O insumo crítico são as enzimas. A questão crítica dos insumos para se produzir etanol em escala industrial é produzir enzimas a um custo viável para produção em larga escala. O barateamento e o aumento da escala na produção de enzimas estão ligados ao desenvolvimento da demanda geral do setor. Por ainda não haver produção de etanol de segunda geração em larga escala, as indústrias de insumos são obrigadas a fabricar pequenos lotes de enzimas específicas a um alto custo. $\mathrm{O}$ aumento de demanda e o aumento de escala depende para esse stakeholder, de incentivos governamentais a fim de aumentar a demanda agregada, em especial com a construção de plantas-piloto e leis de incentivo fiscal para a produção em toda cadeia do etanol de segunda geração.

\section{7) Governo}

Ao tratar-se do desenvolvimento do etanol de segunda geração, nota-se um fato decisivo. A tecnologia para produção já existe, residindo o problema na ampliação de escala produtiva aliada ao barateamento dos processos produtivos. Nesse sentido, o governo tem papel primordial, visto que é o governo que pode estimular a ampliação da demanda por esse combustível, assim como criar incentivos à disseminação dessa tecnologia. O governo tem ainda o papel de regular o mercado, o preço do etanol e da energia elétrica. O preço da gasolina também é controlado pelo governo. Quando 
conjugados, esses fatores podem impulsionar a formação de um mercado de etanol de segunda geração. As variáveis descritas a partir desse stakeholder são de suma importância, com destaque para o financiamento da construção e operação de usinas em escala pré-industrial, incentivos para o término na queima no campo e melhoria das condições trabalhistas.

\section{8) Fabricante de Equipamentos}

As empresas que fabricam equipamentos para o setor são diversificadas, visto que existe uma miríade de fases no processo de produção do etanol de primeira geração. Fabricantes de caldeiras, de peneiras moleculares, de silos, entre outros compõem um espectro heterogêneo de fabricantes. Entretanto, quando se trata do desenvolvimento e capacidade de fornecimento de equipamentos para o etanol de segunda geração encontrou-se apenas uma grande empresa com um departamento de engenharia específico para essa finalidade. Mesmo não sendo economicamente viável para produção em larga escala, essa empresa já investe na tecnologia do etanol de segunda geração há pelo menos uma década. Aqui se destacam duas variáveis. A fabricação de equipamentos para pré-tratamento do bagaço e a fabricação de biorreatores de larga escala.

\section{9) Imprensa Especializada}

A imprensa especializada cumpre papel de informar duas classes de público no setor produtivo de etanol. Primeiro, a classe do público especializado e ligado à cadeia produtiva do etanol. Segundo informar o grande público sobre as questões energéticas da sociedade, em especial no tocante às fontes renováveis de energia. O editor científico consultado relatou informações cruciais sobre o desenvolvimento de organismos geneticamente modificados com objetivo de melhorar a produtividade, além de conquistas importantes por parte dos centros de tecnologia e universidades ligadas aos órgãos de fomento à pesquisa que atuam em São Paulo.

10) Empresas de consultoria financeira, empresas de consultoria em engenharia e centros de pesquisas econômicas. 
Os três stakeholders mostraram-se como catalisadores do desenvolvimento do setor. De fato, as empresas de consultoria fazem a ligação entre os projetos futuros das usinas e a sua realização material. Isso se dá primeiramente com a elaboração de projetos técnicos e ambientais que tornam as iniciativas de investimentos uma iniciativa fisicamente planejada. Em conjunto com esse esforço de planejamento, as empresas de consultoria financeira unificam os projetos técnicos e agregam a eles um planejamento econômicofinanceiro no intuito de captar recursos junto às grandes instituições financeiras nacionais e internacionais. Vale destacar que atualmente alguns projetos de bioenergia já incorporam, através das empresas de consultoria, a captação de recursos via MDL (Mecanismo de Desenvolvimento Limpo) e sua respectiva contabilização de créditos de carbono. Isso aponta o futuro do setor e força a incorporação das tecnologias de segunda geração visto que a mitigação dos gases estufa é severamente favorecida pelo etanol produzido a partir da celulose. Os centros de pesquisa econômica cumprem o papel de orientar as políticas de investimento por parte dos usineiros, através da publicação de índices e relatórios de tendências econômicas.

\section{1) Instituições Financeiras}

Durante a sondagem prévia em que se buscou eleger os stakeholders, descobriu-se que toda a intermediação entre o setor produtivo de etanol e o mercado financeiro se dá através de empresas de consultoria que estruturam os projetos para levantamento de capital. Assim, elegeu-se um especialista que dirige um escritório de consultoria financeira para usinas como informante - ao invés de nomear um profissional ligado diretamente a um banco de investimentos. Durante a entrevista com o especialista eleito, foi descrito o papel do mercado financeiro no setor, principalmente em relação aos agentes financeiros (BID, BNDS, bancos privados e Banco Mundial) no tocante à obtenção de financiamentos para produção do etanol de segunda geração. Variáveis importantes dos aspectos econômicos e sociais foram levantadas.

\section{2) Empresa pública do setor sucroenergético}

Foram identificadas duas empresas públicas que atuam em questões ligadas ao etanol de segunda geração. Uma empresa pública do setor petrolífero e uma empresa pública do setor agropecuário. Em ambos os casos elas desenvolvem pesquisas semelhantes aos 
centros de tecnologia, inclusive com linhas de pesquisa comuns. Destaca-se aqui a pesquisa de equipamentos para a fase agrícola por parte da empresa pública do setor agropecuário.

13) Órgãos de Patente

Os órgãos de patente forçam o desenvolvimento de tecnologia ao garantir os direitos aos royalties referentes ao esforço de pesquisa. Além disso, constituem um importante banco de informações para as usinas, pesquisadores e a imprensa especializada sondarem as inovações realizadas no setor.

\section{4) Montadoras}

As montadoras cumprem papel indireto na consolidação do etanol de segunda geração, mas cumprem papel primordial na geração de demanda por etanol. A tecnologia flexfuel consolidou o mercado de etanol no Brasil, e se levada aos outros países poderá constituir importante mercado internacional para futura produção brasileira do etanol de segunda geração. Além disso, as montadoras vêm trabalhando no desenvolvimento de motores leves e pesados movidos a etanol, o que também força a ampliação de mercado futuro para esse combustível.

Em oposição, algumas montadoras têm investido significativamente em carros elétricos, que podem apresentar uma alternativa aos carros que usam etanol como combustível veicular.

15) Empresa privada de pesquisa tecnológica

As empresas de pesquisa privadas são empresas de alta tecnologia, concentradas na fase agrícola e de capital transnacional que incorporaram ou se fundiram às instituições brasileiras detentoras de conhecimento sobre a genética da cana-de-açúcar. Elas buscam a criação de variedades de cana-de-açúcar mais produtivas e melhor adaptadas ao clima e solo. Produzem variedades resistentes a herbicidas e pragas, nos moldes do que foi feito com a soja no mundo todo. Outra característica importante está na modificação 
genética da cana-de-açúcar a fim de que ela expresse mais sacarose ou celulose visando o aumento de produção de etanol de primeira ou de segunda geração.

A seguir, resumem-se as principais características das instâncias macroambientais apontadas pelos especialistas.

1) Macroambiente Tecnológico

O macroambiente tecnológico que envolve as questões do etanol de segunda geração é diverso e complexo. Muitas variáveis são multidependentes de fatores exógenos e se influenciam mutuamente. A análise comparativa dessas variáveis mostra que a flexibilidade tecno-produtiva das usinas é um fator decisivo para o setor. A produção de plásticos biodegradáveis a partir do etanol é outro fator que pode influenciar decisivamente a questão do etanol de segunda geração, haja visto seu alto valor agregado. A possibilidade de hidrolisar resíduos agrícolas é, de fato, uma variável importante considerando que representará uma matéria prima concorrente ao bagaço.

\section{2) Macroambiente Social}

O aspecto social na cadeia produtiva do etanol é heterogêneo. Na medida em que o Brasil possui a agricultura para produção de energia mais sofisticada do mundo - nos grandes empreendimentos do agrobusiness - produtores menores e periféricos ainda carregam traços do antigo Brasil agrícola e escravocrata. Contratações de trabalhadores legalmente irregulares, baixo grau de escolaridade dos trabalhadores e condições de trabalho insalubres. Soma-se esse problema ao desemprego gerado no campo com a mecanização agrícola, que, se por um lado elimina postos de trabalho insalubres gera uma massa de trabalhadores sem perspectivas de recolocação profissional.

Segundo alguns especialistas o quadro é crítico e são poucas as iniciativas consistentes para a melhora das condições do trabalhador no campo. Outros apontam que as usinas vêm requalificando esses trabalhadores e inserindo-os em regimes de trabalho formais. As entidades de classe da indústria da cana, haja visto seu interesse nos mercados internacionais, têm trabalhado com intuito de legalizar as condições de trabalho visto 
que esse aspecto é um condicionante para abertura de mercados externos. Além disso, o governo vem trabalhando para tentar melhorar esse quadro através de fiscalização, do estabelecimento de compromissos junto aos produtores em mecanizar a colheita, principalmente nas usinas onde ainda ocorre a queima e a colheita manual da cana-deaçúcar. Entretanto, novos problemas surgem como o desemprego e a baixa qualificação da mão-de-obra.

\section{3) Macroambiente Econômico}

Os aspectos econômicos macroambientais definem acima de tudo a velocidade com que o etanol de segunda geração será incorporado pelo setor produtivo. Se os aspectos tecnológicos definem a sua viabilidade, os aspectos econômicos definem o ritmo e a urgência dessa mudança. Vale notar que os preços praticados no mercado de energia são fundamentais para as decisões de investimento, principalmente na aposta de uma nova tecnologia.

A tendência de fusões e aquisições do setor é outro fator que favorece a inovação, pois oxigena o setor com novas posições empresariais, em geral, mais propensas à tomada de risco. Indicadores como câmbio e taxas de juros, por sua vez, concorrem para o estabelecimento da competitividade do setor.

\section{4) Macroambiente Político}

A política macroambiental que interfere na questão do etanol de segunda geração possui uma agenda de poucas e importantes decisões.

A comoditização do etanol é um passo importante para consolidar um mercado mundial de etanol e forçar o fim do protecionismo internacional. A criação de subsídios fiscais para todas as etapas da produção de etanol de segunda geração é fator importante para garantir vantagens ao Brasil.

A questão da diversificação da matriz energética é fundamental para a segurança nacional e é ponto pacífico que não depender de uma fonte única e instável como o petróleo aponta grande vantagem estratégica. 
5) Macroambiente Ecológico (ou aspectos ambientais)

Os aspectos ecológico-ambientais merecem destaque na análise da produção de um combustível renovável. Em primeiro lugar, a produção do etanol de segunda geração aumentaria a eficiência energética do processo de produção de etanol, diminuindo ainda mais o impacto ambiental desse combustível em relação aos derivados de petróleo (em CO2 emitido por unidade energética). Ao possuir uma fase agrícola, o uso da água é outra questão ambiental crítica na produção de etanol. Vale notar que já existe tecnologia para as usinas exportarem água no processo de destilação, ou seja, a fase industrial pode ter um saldo negativo no consumo de água. A adesão ao zoneamento agroambiental deve garantir a preservação da biodiversidade. Por fim, ao lidar com OGMs (Organismos Genéticamente Modificados) o etanol de segunda geração depende de uma regulamentação austera que vise minimizar os riscos ambientais dessa manipulação.

\subsubsection{Quadro final das variáveis apontadas pelos especialistas}

Segue quadro abaixo que organiza as variáveis com os especialsitas e já retificadas por stakeholder da primeira fase da coleta de dados. São as variáveis abaixo que comporão a base da próxima etapa da coleta. As variáveis estão organizadas por stakeholder e numeradas sequencialmente para cada stakeholder.

\section{Quadro 5 - Variáveis por stakeholder}

\begin{tabular}{|l|l|l|l|}
\hline Centro de tecnologia & & Empresa privada de pesquisa tecnológica & \\
\hline $\begin{array}{l}\text { Força o desenvolvimento de microorganismos mais } \\
\text { eficientes }\end{array}$ & 1 & $\begin{array}{l}\text { Força o desenvolvimento de cana } \\
\text { transgênica para aumentar produção na fase } \\
\text { agrícola }\end{array}$ & 1 \\
\hline $\begin{array}{l}\text { Força o desenvolvimento de coquetéis enzimáticos } \\
\text { mais eficientes }\end{array}$ & 2 & Entidade de classe da indústria da cana & \\
\hline $\begin{array}{l}\text { Força o desenvolvimento de métodos mais eficientes } \\
\text { de tratamento do bagaço }\end{array}$ & 3 & $\begin{array}{l}\text { Força abertura de mercados nacionais e } \\
\text { internacionais para o etanol brasileiro }\end{array}$ & 1 \\
\hline $\begin{array}{l}\text { Força a elaboração de simuladores de usinas de etanol } \\
\text { de segunda geração }\end{array}$ & 4 & $\begin{array}{l}\text { Alinha estratégias de pesquisa segundo } \\
\text { necessidades da indústria }\end{array}$ & 2 \\
\hline
\end{tabular}




\begin{tabular}{|c|c|c|c|}
\hline Universidades & & Usina de etanol & \\
\hline Força a criação de centros de pesquisa & 1 & Força a mecanização agrícola & \\
\hline Força a formação de recursos humanos & 2 & $\begin{array}{l}\text { Força a integração da tecnologia de 1.a } \\
\text { geração com a tecnologia de 2.a geração }\end{array}$ & 2 \\
\hline Imprensa especializada & & Órgão de fomento de pesquisa & \\
\hline $\begin{array}{l}\text { Forma a opinião pública favorável ou desfavorável } \\
\text { sobre o etanol de segunda geração }\end{array}$ & 1 & $\begin{array}{l}\text { Financia a pesquisa nos gargalos técnicos } \\
\text { para consolidação do etanol de segunda } \\
\text { geração }\end{array}$ & 1 \\
\hline Empresas de consultoria financeira e técnica & & $\begin{array}{l}\text { Mudanças genéticas e fisiológicas na cana } \\
\text { para pré-hidrolisar o bagaço na fase agrícola }\end{array}$ & 2 \\
\hline $\begin{array}{l}\text { Facilita o desenvolvimento técnico e econômico do } \\
\text { setor }\end{array}$ & 1 & Órgãos de Patentes & \\
\hline Montadoras & & Garante direitos sobre inovação tecnológica & 1 \\
\hline $\begin{array}{l}\text { Força o desenvolvimento de motores leves e pesados } \\
\text { movidos a etanol }\end{array}$ & 1 & $\begin{array}{l}\text { Fonte de informação para aquisição de } \\
\text { tecnologia }\end{array}$ & 2 \\
\hline Força a internacionalização da tecnologia Flex-fuel & 2 & Fabricante de equipamentos & \\
\hline Força a disseminação do carro elétrico & 3 & $\begin{array}{l}\text { Desenvolve e fornece equipamentos para } \\
\text { tratamento do bagaço e produção de enzimas }\end{array}$ & 1 \\
\hline Governo & & $\begin{array}{l}\text { Força o desenvolvimento de biorreatores } \\
\text { para produção em larga escala }\end{array}$ & 2 \\
\hline $\begin{array}{l}\text { Força a construção de plantas de etanol de segunda } \\
\text { geração em escala pré-industrial }\end{array}$ & 1 & Empresa pública do setor sucroenergético & \\
\hline $\begin{array}{l}\text { Força equilíbrio entre oferta e demanda de etanol no } \\
\text { mercado interno }\end{array}$ & 2 & $\begin{array}{l}\text { Força o desenvolvimento de equipamentos } \\
\text { para fase agrícola }\end{array}$ & 1 \\
\hline $\begin{array}{l}\text { Força a construção de alcooldutos e a utilização da } \\
\text { infra-estrutura petroquímica }\end{array}$ & 3 & & \\
\hline Aspectos tecnológicos & & Aspectos econômicos & \\
\hline Produção de plástico biodegradável a partir do etanol & 1 & Preço do açúcar & 1 \\
\hline $\begin{array}{l}\text { Produção simultânea de etanol de segunda geração, } \\
\text { açúcar, bioeletrecidade e derivados }\end{array}$ & 2 & Preço do petróleo & 2 \\
\hline Viabilidade de hidrolisar resíduos agrícolas & 3 & Valor relativo das moedas estrangeiras & 3 \\
\hline $\begin{array}{l}\text { Aproveitamento do bagaço pós-hidrólise para } \\
\text { fabricação de ração animal }\end{array}$ & 4 & Descoberta de jazidas de petróleo & 4 \\
\hline $\begin{array}{l}\text { Pesquisa brasileira em biocombustíveis é } \\
\text { internacionalizada e possuidora de classe mundial }\end{array}$ & 5 & $\begin{array}{l}\text { Logística brasileira favorável para uso da } \\
\text { biomassa (bagaço) }\end{array}$ & 5 \\
\hline Aspectos sociais & & Baixo preço da energia elétrica & 6 \\
\hline Adequação do setor às normas trabalhistas & 1 & Tendência de fusões e aquisições no setor & 7 \\
\hline Término da queima e da colheita manual da cana & 2 & $\begin{array}{l}\text { Força menores taxas de juros para } \\
\text { financiamento de tecnologia de segunda } \\
\text { geração }\end{array}$ & 8 \\
\hline Recolocação motivada pela mecanização do campo & 3 & Preço do etanol & 9 \\
\hline Competição com alimentos por uso da terra & 4 & $\begin{array}{l}\text { Alto potencial produtivo de biomassa no } \\
\text { Brasil }\end{array}$ & 10 \\
\hline
\end{tabular}




\begin{tabular}{|c|c|c|c|}
\hline Aspectos Ambientais & & Aspectos políticos & \\
\hline $\begin{array}{l}\text { Diminuição do impacto ambiental promovido pelo } \\
\text { etanol de segunda geração }\end{array}$ & 1 & Comoditização do etanol & 1 \\
\hline Agravamento das mudanças climáticas & 2 & $\begin{array}{l}\text { Criação de subsídios para consolidação do } \\
\text { etanol de segunda geração }\end{array}$ & 2 \\
\hline Uso sustentável da água & 3 & $\begin{array}{l}\text { Ausência de tarifas alfandegárias nos EUA } \\
\text { para o açúcar produzido no nordeste } \\
\text { brasileiro }\end{array}$ & 3 \\
\hline Biossegurança de OGMs & 4 & $\begin{array}{l}\text { Aspecto estratégico na diversificação da } \\
\text { matriz energética }\end{array}$ & 4 \\
\hline Fixação de metas internacionais de emissões de CO2 & 5 & \multirow[t]{2}{*}{ Protecionismo estrangeiro } & 5 \\
\hline Adesão ao zoneamento agroambiental & 6 & & \\
\hline
\end{tabular}

\subsection{Segunda fase da coleta de dados}

A segunda fase da coleta de dados tem por objetivo qualificar as variáveis. Essa qualificação se dá em duas instâncias. Primeiro quanto à importância da variável no ambiente estudado. Segundo, sobre a natureza da variável ser uma tendência ou uma incerteza. Isso se dá através de um questionário aplicado aos especialistas, questionário esse que faz uso de escalas. A idéia fundamental é eleger quais são as variáveis que irão para a próxima etapa de estudo, ou seja, eleger as variáveis de maior importância e eliminar as variáveis de menor importância, atribuindo ainda graus de incerteza que essas variáveis venham a possuir.

\subsubsection{Qualificação das variáveis}

Dez especialistas participaram dessa etapa. O assessor para assuntos ligados à etanol do secretário de meio ambiente do Estado de São Paulo foi substituído pela diretora técnica da Secretaria de Meio Ambiente do Estado de São Paulo. O presidente de uma empresa fabricante de insumos foi substituído pelo gerente de marketing dessa mesma empresa.

Foi apresentado aos especialistas o roteiro da coleta de dados, assim como as escalas utilizadas e as tabelas para coleta. O questionário está no ANEXO 3. Feito isso as 59 variáveis da primeira etapa foram avaliadas segundo:

A importância da variável na escala: 
(-5) - variável de muito baixa importância no ambiente;

(-4) ... (-1) - variáveis intermediárias;

(0) - variável de média importância no ambiente;

(1) ... (4) - variáveis intermediárias; e

(5) - variável de muito alta importância no ambiente.

$-5$

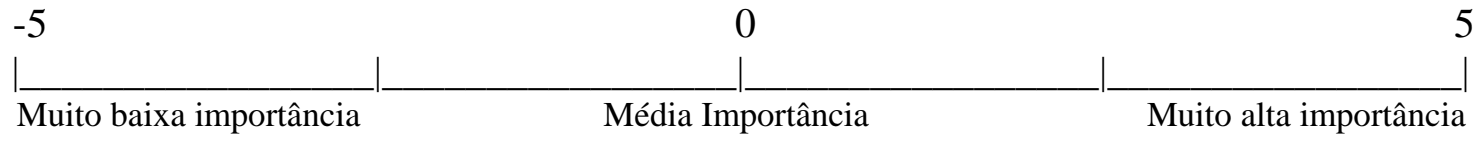

\subsubsection{Análise do quesito importância das variáveis}

Após a realização da coleta com os dez especialistas selecionados o quesito importância foi quantificado para as 59 variáveis consolidadas na primeira etapa. A tabela 1 mostra os valores respectivos da média da importância de cada variável considerando os dez especialistas:

\section{Tabela 1 - Médias da Importância das variáveis por stakeholder}

Nesta segunda etapa, a média de pontos atribuídos para uma escala de (-5) a (5) foi de 2,52, e embora a freqüencia de três atribuições de graus importância (3, 4 e 5) ser superior às outras frequencias, o ponto médio das respostas ficou em torno de 2,5. O desvio padrão das médias de importância obteve o valor de 1,33 . O primeiro quartil apontou 1,9, o segundo quartil 2,7 e o terceiro quartil 3,3. Como a maioria das respostas se concentrou nos valores mais altos da escala, pode-se dizer que houve maior concordância entre os especialistas naquelas variáveis a que atribuiu-se as notas mais altas. A figura 10 representa tais freqüências: 


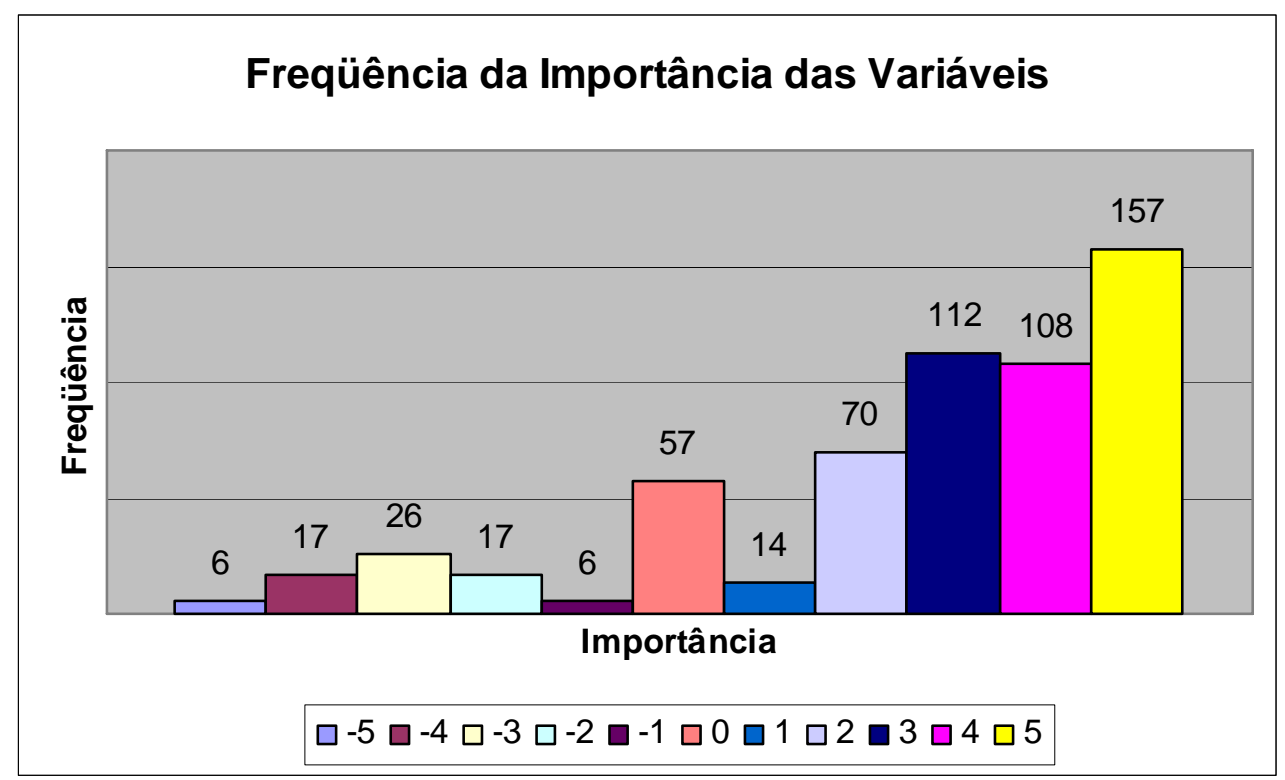

Figura 10 - Gráfico de frequência da importância das variáveis

O critério para seleção das variáveis dessa etapa para a etapa seguinte reside justamente no grau de importância média das variáveis avaliadas. O critério de corte e seleção foi constituído da seguinte forma: As variáveis que apresentaram média de importância superior ao terceiro quartil $(3,3)$ foram selecionadas.

\subsubsection{Análise do quesito incerteza das variáveis}

Esse segundo procedimento, referente à segunda etapa da coleta de dados, visa qualificar as variáveis quanto ao seu grau de incerteza, de forma que, ao final, as variáveis possam pertencer a uma de duas possíveis classes: a classe de "tendencia" ou a classe de "incerteza".

Este é um processo fundamental para a construção de cenários visto que as variações nos cenários possíveis estão diretamente ligada às incertezas estabelecidas. Ou seja, ao imaginar os diferentes comportamentos das variáveis incertas obtém-se os diferentes matizes dos cenários futuros.

As questões foram dirigidas aos especialistas tendo como base a qualificação do grau de incerteza das variáveis segundo a seguinte escala (o questionário completo está no ANEXO 3): 
A incerteza da variável na escala:

(-5) - a variável é uma certeza;

(-4) ... (-1) - variáveis intermediárias;

(0) - a variável é provável;

(1) ... (4) - variáveis intermediárias; e

(5) - variável é totalmente incerta.

| É uma certeza

O processo para identificar a incerteza foi adaptado ao descrito na metodologia. De fato, durante a adaptação dos questionários e plotagem dos dados na matriz, optou-se por convencionar para a escala de valores que um valor negativo representaria um maior grau de certeza e um valor positivo a um maior grau de incerteza. Ou seja, trata-se de uma escala de incerteza que vai da certeza à incerteza tendo o zero como um atributo "provável" sobre a variável em questão. Como resultado os valores de incerteza ficaram plotados na parte superior do gráfico e os valores de certeza na parte inferior do gráfico.

A média de incerteza das variáveis foi negativa apontando $(-0,5)$, ou seja, apresentou-se uma leve tendência para o aspecto de "certeza" das variáveis, e, como o valor ficou próximo de zero, pode-se dizer que houve uma distribuição equilibrada nas variáveis quanto a certeza-incerteza das mesmas.

O primeiro quartil acusou $(0,35)$, o segundo quartil $(-0,6)$ e o terceiro quartil $(-1,2)$. $O$ desvio padrão acusou o valor de $(1,19)$. A atribuição de incerteza ou certeza das variáveis se deu através da própria escala, ou seja, variáveis com valores de incerteza superiores a zero foram tidas como variáveis de "incerteza". Por outro lado, variáveis com valor de incerteza negativa foram tidas como variáveis de "tendência".

A distribuição de freqüência dos valores de incerteza estão descritas no gráfico da Fig. 11: 


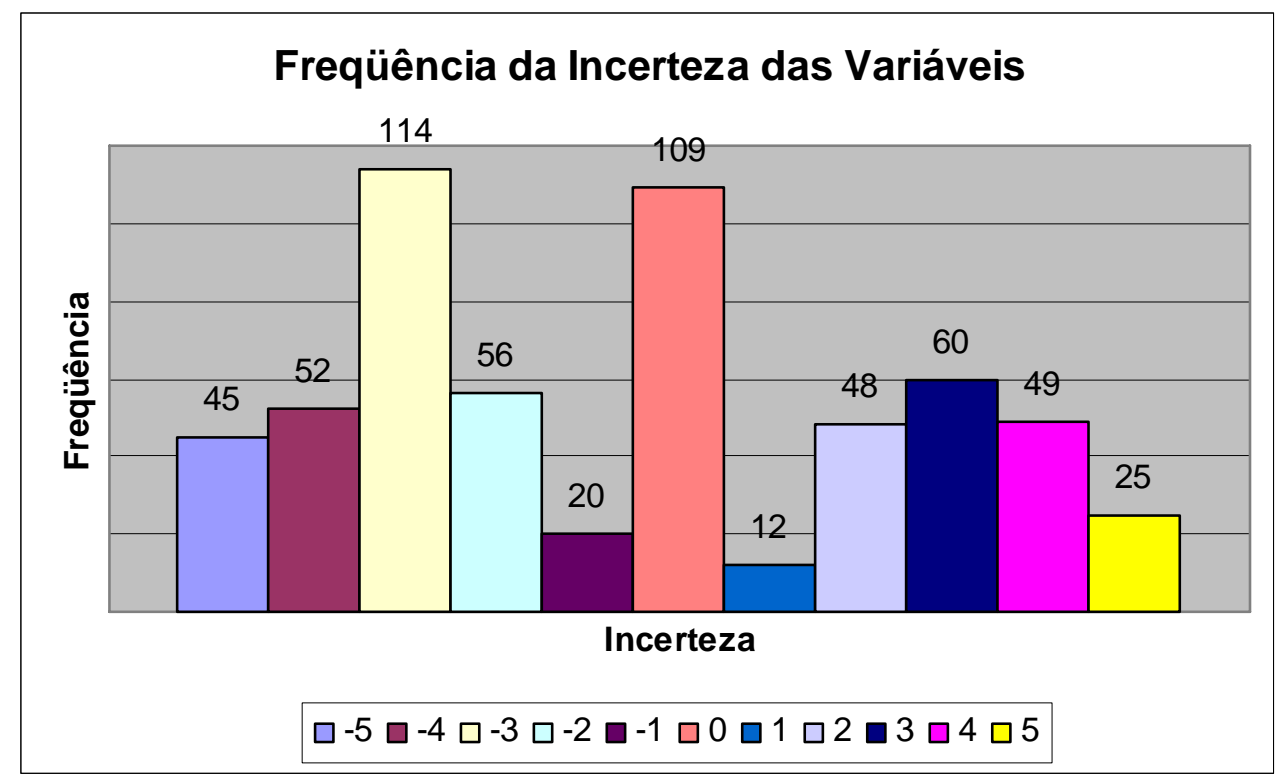

Figura 11 - Gráfico de frequência da incerteza das variáveis

\subsubsection{Matriz de importância e incerteza}

Depois de estabelecida a importância e a incerteza das variáveis, os dados foram combinados na forma de uma matriz. Ao plotar os pontos para cada variável, o valor do eixo horizontal correspondeu à importância da variável e o eixo vertical ao grau de incerteza. Vale notar que na adaptação da matriz de importância e incerteza para esse trabalho optou-se por padronizar os valores positivos do eixo vertical correspondendo a grau crescente de incerteza. Segue a matriz na fig. 12: 


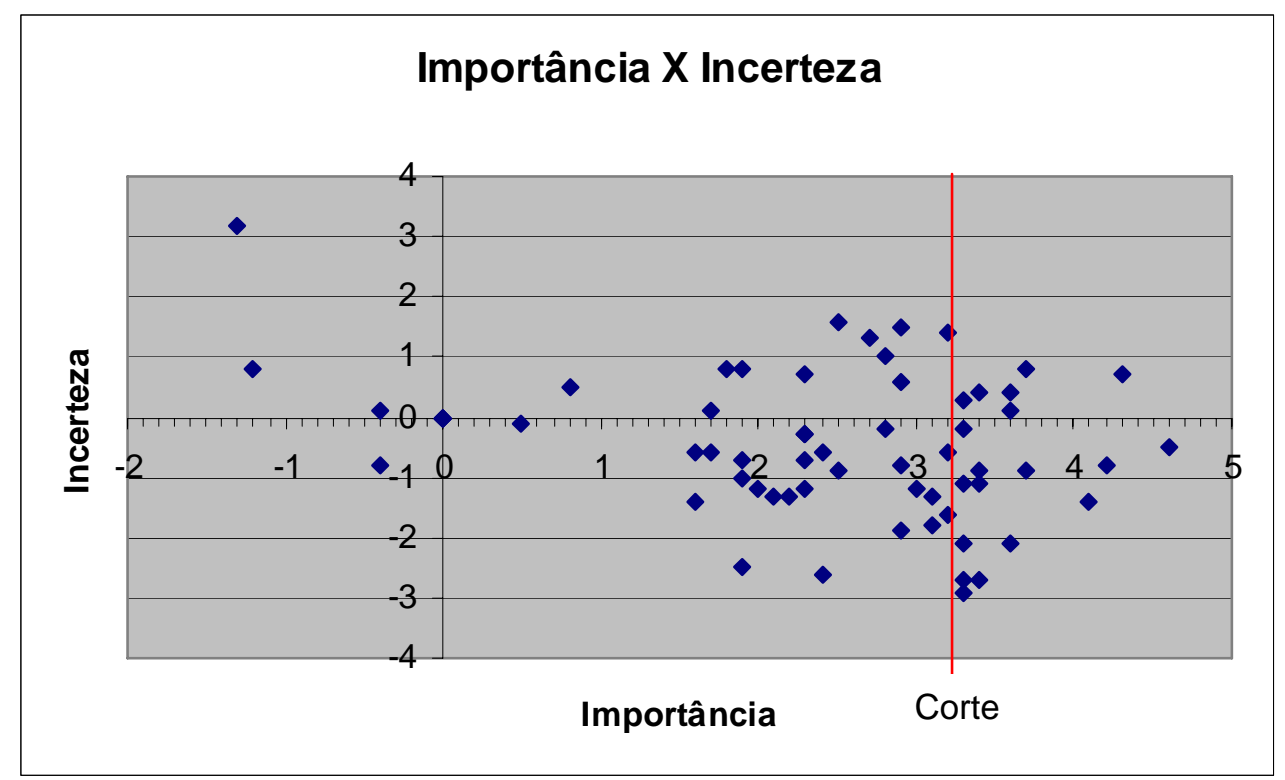

Figura 12 - Gráfico da matriz de importância e incerteza

A seleção das variáveis para a próxima etapa do estudo se deu através do corte à direita do terceiro quartil $(3,3)$ no eixo horizontal (importância). Além da eleição das dezenove variáveis que se situaram no terceiro quartil, duas variáveis foram incluídas pelo fato de serem fatores críticos para o desenvolvimento do etanol de segunda geração, a variável (Usinas 3 - Concorrência pelo bagaço entre etanol de segunda geração e a bioeletricidade) e (Órgãos de fomento à pesquisa 2 - Mudanças genéticas e fisiológicas na cana para pré hidrolizar o bagaço na fase agrícola).

Essas duas variáveis foram incluídas por serem variáveis fundamentais para o desenvolvimento tecnológico do etanol de segunda geração. No caso da variável Usinas - 3, especialistas ligados à usinas de etanol de primeira geração atribuíram nota máxima para importância dessa variável em relação ao futuro do etanol de segunda geração, principalmente porque a decisão futura de investimento em tecnologia de segunda geração concorre diretamente com o investimento na tecnologia de geração de eletritcidade com a queima do bagaço na usina. A variável Órgãos de Fomento à pesquisa - 2, foi selecionada para a fase seguinte por dois motivos. Primeiro, foi atribuida nota máxima na sua importância pelos especialistas ligados ao fomento de pesquisa tecnológica para o etanol de segunda geração. Também pelo fato de ser uma variável nova, que alguns dos outros especialistas das áreas econômica e política não tinham conhecimento da importância respectiva. Por esse motivo, decidiu-se incluí-las 
na próxima etapa da pesquisa. Das vinte e uma variáveis selecionadas, doze pertecem ao macroambiente e nove aos stakeholders. O fato da maior parte das variáveis pertecer ao macro-ambiente está ligado ao aspecto complexo e de longo prazo do desenvolvimento do etanol de segunda geração. Por se tratar de um desenvolvimento referente à mudança da matriz energética de um país, muitos fatores de influência abrangente fazem parte da análise. A tabela 1 apresenta os dados consolidados dessa etapa:

Tabela 1 - Média e desvio padrão das variáveis usadas na segunda fase do estudo

\begin{tabular}{|c|c|c|c|c|}
\hline Dados - Segunda Fase do Estudo & & & Desvio & drão \\
\hline Variáveis & Importância & Incerteza & Importância & Incerteza \\
\hline $\begin{array}{l}\text { Adequação do setor às normas } \\
\text { trabalhistas }\end{array}$ & 3,3 & $-0,2$ & 2,45 & 2,82 \\
\hline $\begin{array}{l}\text { Adesão ao zonamento } \\
\text { agroambiental }\end{array}$ & 2,4 & $-2,6$ & 2,59 & 2,76 \\
\hline $\begin{array}{l}\text { Agravamento das mudanças } \\
\text { climáticas }\end{array}$ & 3,3 & $-1,1$ & 2,11 & 2,38 \\
\hline $\begin{array}{l}\text { Alinha estratégias de pesquisa } \\
\text { segundo necessidades da indústria }\end{array}$ & 2,9 & $-1,9$ & 1,97 & 2,77 \\
\hline \begin{tabular}{|l|}
$\begin{array}{l}\text { Alto potencial produtivo de } \\
\text { biomassa no Brasil }\end{array}$ \\
\end{tabular} & 3,6 & $-2,1$ & 1,35 & 3,87 \\
\hline $\begin{array}{l}\text { Aproveitamento do bagaço pós- } \\
\text { hidrólise para fabricação de ração } \\
\text { animal }\end{array}$ & $-1,2$ & 0,8 & 2,53 & 3,05 \\
\hline $\begin{array}{l}\text { Aspecto estratégico na } \\
\text { diversificação da matriz } \\
\text { energética }\end{array}$ & 3,6 & 0,4 & 1,07 & 2,76 \\
\hline $\begin{array}{l}\text { Ausência de tarifas alfandegárias } \\
\text { nos EUA para o açúcar produzido } \\
\text { no nordeste brasileiro }\end{array}$ & $-0,4$ & 0,1 & 3,69 & 3,07 \\
\hline Baixo preço da energia elétrica & 2,7 & 1,3 & 2,5 & 2,71 \\
\hline Biossegurança de OGMs & 1,6 & $-1,4$ & 3,6 & 2,88 \\
\hline Comoditização do etanol & 3,4 & 0,4 & 1,51 & 3,27 \\
\hline $\begin{array}{l}\text { Competição com alimentos por } \\
\text { uso da terra }\end{array}$ & $-0,4$ & $-0,8$ & 3,57 & 3,29 \\
\hline $\begin{array}{l}\text { Concorrência pelo bagaço entre } \\
\text { etanol de segunda geração e a } \\
\text { bioeletrecidade }\end{array}$ & 3,2 & $-0,6$ & 1,87 & 2,37 \\
\hline $\begin{array}{l}\text { Criação de subsídios para } \\
\text { consolidação do etanol de segunda } \\
\text { geração }\end{array}$ & 3,3 & 0,3 & 2,67 & 2 \\
\hline Descoberta de jazidas de petróleo & 2,3 & 0,7 & 2,16 & 2,98 \\
\hline $\begin{array}{l}\text { Desenvolve e fornece } \\
\text { equipamentos para tratamento do } \\
\text { bagaço e produção de enzimas }\end{array}$ & 3,2 & $-1,6$ & 1,55 & 2,07 \\
\hline
\end{tabular}




\begin{tabular}{|c|c|c|c|c|}
\hline Dados - Segunda Fase do Estudo & & & Desvio 1 & drão \\
\hline Variáveis & Importância & Incerteza & Importância & Incerteza \\
\hline $\begin{array}{l}\text { Diminuição do impacto ambiental } \\
\text { promovido pelo etanol de segunda } \\
\text { geração }\end{array}$ & 3,1 & $-1,8$ & 2,81 & 3,19 \\
\hline $\begin{array}{l}\text { Facilita o desenvolvimento técnico } \\
\text { e econômico do setor }\end{array}$ & 2,3 & $-0,3$ & 1,7 & 2,54 \\
\hline $\begin{array}{l}\text { Financia a pesquisa nos gargalos } \\
\text { técnicos para consolidação do } \\
\text { etanol de segunda geração }\end{array}$ & 3,3 & $-2,1$ & 2,83 & 2,38 \\
\hline $\begin{array}{l}\text { Fixação de metas internacionais } \\
\text { de emissões de CO2 }\end{array}$ & 2,9 & 0,6 & 2,92 & 3,13 \\
\hline $\begin{array}{l}\text { Fonte de informação para } \\
\text { aquisição de tecnologia }\end{array}$ & 0,5 & $-0,1$ & 1,72 & 2,56 \\
\hline $\begin{array}{l}\text { Força a construção de alcooldutos } \\
\text { e a utilização da infra-estrutura } \\
\text { petroquímica }\end{array}$ & 1,9 & -1 & 3,57 & 2,49 \\
\hline $\begin{array}{l}\text { Força a construção de plantas de } \\
\text { etanol de segunda geração em } \\
\text { escala pré-industrial }\end{array}$ & 2,5 & 1,6 & 2,64 & 2,22 \\
\hline $\begin{array}{l}\text { Força a criação de centros de } \\
\text { pesquisa }\end{array}$ & 2,8 & $-0,2$ & 2,78 & 3,61 \\
\hline $\begin{array}{l}\text { Força a disseminação do carro } \\
\text { elétrico }\end{array}$ & $-1,3$ & 3,2 & 1,95 & 2,15 \\
\hline $\begin{array}{l}\text { Força a elaboração de simuladores } \\
\text { de usinas de etanol de segunda } \\
\text { geração }\end{array}$ & 3 & $-1,2$ & 1,49 & 3,01 \\
\hline $\begin{array}{l}\text { Força a formação de recursos } \\
\text { humanos }\end{array}$ & 4,2 & $-0,8$ & 0,79 & 3,01 \\
\hline $\begin{array}{l}\text { Força a integração da tecnologia } \\
\text { de 1.a geração com a tecnologia de } \\
\text { 2.a geração } \\
\end{array}$ & 4,1 & $-1,4$ & 0,88 & 3,13 \\
\hline $\begin{array}{l}\text { Força a internacionalização da } \\
\text { tecnologia Flex-fuel }\end{array}$ & 2,8 & 1 & 2,39 & 2,54 \\
\hline Força a mecanização agrícola & 3,4 & $-2,7$ & 2,55 & 3,16 \\
\hline $\begin{array}{l}\text { Força abertura de mercados } \\
\text { nacionais e internacionais para o } \\
\text { etanol brasileiro }\end{array}$ & 3,4 & $-0,9$ & 2,37 & 2,69 \\
\hline $\begin{array}{l}\text { Força diminuição do custo de } \\
\text { produção das enzimas através do } \\
\text { aumento da escala produtiva }\end{array}$ & 2,5 & $-0,9$ & 2,72 & 2,96 \\
\hline $\begin{array}{l}\text { Força equilíbrio entre oferta e } \\
\text { demanda de etanol no mercado } \\
\text { interno }\end{array}$ & 2,1 & $-1,3$ & 2,51 & 2,98 \\
\hline $\begin{array}{l}\text { Força menores taxas de juros para } \\
\text { financiamento de tecnologia de } \\
\text { segunda geração }\end{array}$ & 3,2 & 1,4 & 1,75 & 2,17 \\
\hline $\begin{array}{l}\text { Força o desenvolvimento de } \\
\text { biorreatores para produção em } \\
\text { larga escala }\end{array}$ & 2,3 & $-1,2$ & 2,63 & 2,2 \\
\hline
\end{tabular}




\begin{tabular}{|c|c|c|c|c|}
\hline Dados - Segunda Fase do Estudo & & & Desvio & drão \\
\hline Variáveis & Importância & Incerteza & Importância & Incerteza \\
\hline $\begin{array}{l}\text { Força o desenvolvimento de cana } \\
\text { trangênica para aumentar } \\
\text { produção na fase agrícola }\end{array}$ & 2,2 & $-1,3$ & 1,55 & 2,26 \\
\hline $\begin{array}{l}\text { Força o desenvolvimento de } \\
\text { equipamentos para fase agrícola }\end{array}$ & 0,8 & 0,5 & 2,86 & 2,42 \\
\hline $\begin{array}{l}\text { Força o desenvolvimento } \\
\text { métodos mais eficientes } \\
\text { tratamento do bagaço }\end{array}$ & 3,1 & $-1,3$ & 1,66 & 3,3 \\
\hline $\begin{array}{l}\text { Força o desenvolvimento de } \\
\text { microorganismos mais eficientes }\end{array}$ & 2,9 & 1,5 & 2,42 & 2,76 \\
\hline $\begin{array}{l}\text { Força o desenvolvimento de } \\
\text { motores leves e pesados movidos à } \\
\text { etanol }\end{array}$ & 1,9 & 0,8 & 3,54 & 2,74 \\
\hline $\begin{array}{l}\text { Forma a opinião pública favorável } \\
\text { ou desfavorável sobre o etanol de } \\
\text { segunda geração }\end{array}$ & 1,6 & $-0,6$ & 2,91 & 2,67 \\
\hline $\begin{array}{l}\text { Garante direitos sobre inovação } \\
\text { técnológica }\end{array}$ & 1,9 & $-0,7$ & 2,56 & 2,45 \\
\hline $\begin{array}{l}\text { Logística brasileira favorável para } \\
\text { uso da biomassa (bagaço) }\end{array}$ & 3,3 & $-2,9$ & 1,06 & 3,31 \\
\hline $\begin{array}{l}\text { Mudanças genéticas e fisiológicas } \\
\text { na cana para pré-hidrólisar o } \\
\text { bagaço na fase agrícola }\end{array}$ & 2,3 & $-0,7$ & 2,91 & 2,75 \\
\hline $\begin{array}{l}\text { Pesquisa brasileira em } \\
\text { biocombustíveis é } \\
\text { internacionalizada e possuidora de } \\
\text { classe mundial }\end{array}$ & 3,7 & $-0,9$ & 1,06 & 2,96 \\
\hline Preço do açúcar & 1,7 & 0,1 & 3,37 & 3 \\
\hline Preço do etanol & 4,6 & $-0,5$ & 0,7 & 3,14 \\
\hline Preço do petróleo & 4,3 & 0,7 & 1,06 & 4,14 \\
\hline $\begin{array}{l}\text { Produção de plástico } \\
\text { biodegradável a partir do etanol }\end{array}$ & 2,4 & $-0,6$ & 3,1 & 2,59 \\
\hline $\begin{array}{l}\text { Produção simultânea de etanol de } \\
\text { segunda geração, açúcar, } \\
\text { bioeletrecidade e derivados }\end{array}$ & 2,9 & $-0,8$ & 2,51 & 3,79 \\
\hline Protecionismo estrangeiro & 2,3 & $-0,3$ & 2,58 & 2,41 \\
\hline $\begin{array}{l}\text { Recolocação motivada pela } \\
\text { mecanização do campo }\end{array}$ & 1,7 & $-0,6$ & 3,43 & 2,12 \\
\hline $\begin{array}{l}\text { Tendência de fusões e aquisições } \\
\text { no setor }\end{array}$ & 3,3 & $-2,7$ & 1,42 & 2,71 \\
\hline $\begin{array}{l}\text { Término da queima e da colheita } \\
\text { manual da cana }\end{array}$ & 3,4 & $-1,1$ & 2,41 & 2,6 \\
\hline Uso sustentável da água & 2 & $-1,2$ & 3,02 & 2,53 \\
\hline $\begin{array}{l}\text { Valor relativo das moedas } \\
\text { estrangeiras }\end{array}$ & 1,8 & 0,8 & 2,25 & 3,29 \\
\hline $\begin{array}{l}\text { Viabilidade de hidrolizar resíduos } \\
\text { agrícolas }\end{array}$ & 3,7 & 0,8 & 1,49 & 3,61 \\
\hline
\end{tabular}




\subsubsection{Variáveis selecionadas para terceira etapa do estudo}

O resultado final da segunda etapa do estudo encontra-se no quadro 6 que contém a lista das variáveis selecionadas para tereira fase do estudo, sua descrição e a categoria (tendência ou incerteza) a que essas variáveis pertencem.

\section{Quadro 6 - Variáveis qualificadas para identificação das variáveis-chaves}

\begin{tabular}{|c|c|c|}
\hline Variável & Descrição & Categoria \\
\hline Usinas - 1 & Força a mecanização agrícola & Tendência \\
\hline Aspectos Ambientais - 2 & Agravamento das mudanças climáticas & Tendência \\
\hline Aspectos Econômicos - 10 & $\begin{array}{l}\text { Alto potencial produtivo de biomassa no } \\
\text { Brasil }\end{array}$ & Tendência \\
\hline Aspectos Econômicos - 2 & Preço do petróleo & Incerteza \\
\hline Aspectos Econômicos - 5 & $\begin{array}{l}\text { Logística brasileira favorável para uso da } \\
\text { biomassa (bagaço) }\end{array}$ & Tendência \\
\hline Aspectos Econômicos - 7 & $\begin{array}{l}\text { Tendência de fusões e aquisições no } \\
\text { setor }\end{array}$ & Tendência \\
\hline Aspectos Econômicos - 9 & Preço do etanol & Tendência \\
\hline Aspectos Políticos - 1 & Comoditização do etanol & Incerteza \\
\hline Aspectos Políticos - 2 & $\begin{array}{l}\text { Criação de subsídios para consolidação } \\
\text { do etanol de segunda geração }\end{array}$ & Incerteza \\
\hline Aspectos Políticos - 4 & $\begin{array}{l}\text { Aspecto estratégico na diversificação da } \\
\text { matriz energética }\end{array}$ & Incerteza \\
\hline Aspectos Sociais - 1 & $\begin{array}{l}\text { Adequação do setor às normas } \\
\text { trabalhistas }\end{array}$ & Tendência \\
\hline Aspectos Sociais - 2 & $\begin{array}{l}\text { Término da queima e da colheita manual } \\
\text { da cana }\end{array}$ & Tendência \\
\hline Aspectos Tecnológicos - 3 & $\begin{array}{l}\text { Viabilidade de hidrolisar resíduos } \\
\text { agrícolas }\end{array}$ & Incerteza \\
\hline Aspectos Tecnológicos - 5 & $\begin{array}{l}\text { Pesquisa brasileira em biocombustíveis é } \\
\text { internacionalizada e possuidora de classe } \\
\text { mundial }\end{array}$ & Tendência \\
\hline Centro de Tecnologia - 2 & $\begin{array}{l}\text { Força o desenvolvimento de coquetéis } \\
\text { enzimáticos mais eficientes }\end{array}$ & Incerteza \\
\hline Entidade de Classe - 1 & $\begin{array}{l}\text { Força abertura de mercados nacionais e } \\
\text { internacionais para o etanol brasileiro }\end{array}$ & Tendência \\
\hline Órgãos de Fomento à Pesquisa - 1 & $\begin{array}{l}\text { Financia a pesquisa nos gargalos } \\
\text { técnicos para consolidação do etanol de } \\
\text { segunda geração }\end{array}$ & Tendência \\
\hline
\end{tabular}




\begin{tabular}{|l|l|l|}
\hline Variável & Descrição & Categoria \\
\hline Órgãos de Fomento à Pesquisa - 2 & $\begin{array}{l}\text { Mudanças genéticas e fisiológicas na } \\
\text { cana para pré-hidrólisar o bagaço na fase } \\
\text { agrícola }\end{array}$ & Tendência \\
\hline Universidade - 2 & Força a formação de recursos humanos & Tendência \\
\hline Usinas - 2 & $\begin{array}{l}\text { Força a integração da tecnologia de 1.a } \\
\text { geração com a tecnologia de 2.a geração }\end{array}$ & Tendência \\
\hline Usinas - 3 & $\begin{array}{l}\text { Concorrência pelo bagaço entre etanol de } \\
\text { segunda geração e a bioeletrecidade }\end{array}$ & Tendência \\
\hline
\end{tabular}

\subsection{Terceira Fase da coleta de dados}

Nessa etapa buscou-se identificar quais variáveis condicionam as demais, assim como estabelecer uma tipologia de comportamento das mesmas quanto a sua influência e dependência.

\subsubsection{Identificação das variáveis-chaves do estudo}

Uma vez obtidas as variáveis mais importantes e sua natureza quanto à incerteza, tomase por objetivo descobrir quais são as variáveis que condicionam o sistema em estudo, ou seja, quais variáveis influenciam as demais ou delas são dependentes. Com isso, espera-se obter as variáveis-chaves do sistema, e a partir delas construir os cenários para o etanol de segunda geração em São Paulo para os próximos dez anos.

O método empregado, reside em combinar as variáveis selecionadas na etapa anterior e analizá-las aos pares, primeiro comparando sua importância relativa, ou seja, identificando qual é a mais importante, segundo, identificando se existe dependência entre elas, se essa relação de dependência é de causa ou efeito e finalmente se o grau dessa dependência é alto, médio ou baixo. Pontos foram atribuídos para a influência e dependência das variáveis, conforme se descreve abaixo.

O questionário de apoio a esta etapa da pesquisa está no ANEXO 3. 
A combinação dos pares das 21 variáveis selecionadas na etapa anterior geraram 20 planilhas de coleta de dados que continham as combinações possíveis entre as 21 variáveis, resultando em 210 questões. Os especialistas foram consultados um a um, sendo que dada a extensão do questionário desta terceira etapa, alguns tiveram que respondê-lo em mais de um encontro.

Para que se computassem os dados do quesito influência, atribuiu-se pontos positivos acumuláveis na razão de 1 (um) ponto, para cada variável à qual fosse atribuída uma influência maior que à comparada. Portanto, a pontuação máxima de influência obtida por uma variável foi de 20 pontos.

Para o quesito dependência, primeiro identificou-se se havia uma relação de interdependência entre os pares de variáveis comparados. Em seguida, identificou-se qual era a variável causa e qual era a variável efeito dessa relação. Então, fora atribuido 1, 2 ou 3 pontos acumuláveis para os graus baixo, médio ou alto desta dependência sobre as variáveis efeito. Assim, a pontuação máxima para o quesito dependência foi de 60 pontos.

Os dez especialistas foram consultados e foram calculadas as médias das respostas para cada variável de influência e dependência, e as médias foram normalizadas. Para as médias de influência a pontuação máxima (20) foi equiparada a uma escala de 100 pontos. Para os valores de dependência a normalização se deu equiparando o valor médio das 21 variáveis a 50 pontos.

\subsubsection{Resultados da influência e dependência das variáveis}

Os resultados apontaram que duas variáveis condicionam o sistema como um todo. A variável mais influênte foi a referente aos órgãos de fomento à pesquisa, financia a pesquisa nos gargalos técnicos para consolidação do etanol de segunda geração, com 77 pontos. A variável menos influente foi a referente aos aspectos sociais (adequação às normas trabalhistas) com 23 pontos de influência. A variável menos dependente foi o preço do petróleo, com dependência 0 em relação às outras variáveis. A variável mais dependente foi a referente à concorrência pelo bagaço entre a geração de energia elétrica e produção de etanol de segunda geração $(84,1)$. 
A tabela 1 aponta os valores medianos da influência e da dependência das variáveis estudadas na terceira etapa com a respectiva normalização:

Tabela 2 - Médias e normalização da influência e da dependência das variáveis

\begin{tabular}{|c|c|c|c|c|}
\hline Variável & $\begin{array}{c}\text { Média } \\
\text { Influência }\end{array}$ & $\begin{array}{c}\text { Média } \\
\text { Dependência }\end{array}$ & $\begin{array}{c}\text { Influência } \\
\text { Normalizada }\end{array}$ & $\begin{array}{l}\text { Dependência } \\
\text { Normalizada }\end{array}$ \\
\hline Aspectos Sociais - 1 & 4,6 & 10,0 & 23,0 & 44,1 \\
\hline Aspectos Ambientais - 2 & 8,8 & 2,8 & 44,0 & 12,3 \\
\hline Aspectos Econômicos - 10 & 11,4 & 6,2 & 57,0 & 27,3 \\
\hline Aspectos Econômicos - 2 & 11,5 & 0,0 & 57,5 & 0,0 \\
\hline Aspectos Econômicos - 5 & 11,4 & 9,3 & 57,0 & 41,0 \\
\hline Aspectos Econômicos - 7 & 9,5 & 10,1 & 47,5 & 44,5 \\
\hline Aspectos Econômicos - 9 & 8,1 & 16,6 & 40,5 & 73,1 \\
\hline Aspectos Políticos - 1 & 10,9 & 14,0 & 54,5 & 61,7 \\
\hline Aspectos Políticos - 2 & 14,5 & 8,5 & 72,5 & 37,4 \\
\hline Aspectos Políticos - 4 & 6,1 & 12,3 & 30,5 & 54,2 \\
\hline Aspectos Sociais - 2 & 6,9 & 10,2 & 34,5 & 44,9 \\
\hline Aspectos Tecnológicos - 3 & 6,7 & 17,3 & 33,5 & 76,2 \\
\hline Aspectos Tecnológicos - 5 & 8,5 & 10,5 & 42,5 & 46,3 \\
\hline Centro Tec.- 2 & 15,1 & 14,6 & 75,5 & 64,3 \\
\hline Entidade de Classe - 1 & 10,7 & 17,6 & 53,5 & 77,5 \\
\hline $\begin{array}{l}\text { Órgãos de Fomento à } \\
\text { Pesquisa - } 1\end{array}$ & 15,4 & 10,2 & 77,0 & 44,9 \\
\hline $\begin{array}{l}\text { Órgãos de Fomento à } \\
\text { Pesquisa - } 2 \\
\end{array}$ & 11,2 & 12,3 & 56,0 & 54,2 \\
\hline Universidade - 2 & 9,2 & 9,4 & 46,0 & 41,4 \\
\hline Usinas - 1 & 7,3 & 8,6 & 36,5 & 37,9 \\
\hline Usinas - 2 & 9,4 & 18,8 & 47,0 & 82,8 \\
\hline Usinas - 3 & 12,8 & 19,1 & 64,0 & 84,1 \\
\hline
\end{tabular}

O desvio padrão das variáveis estudadas nessa etapa apresentou os seguintes valores: 
Tabela 3 - Desvio padrão da influência e dependência das variáveis

\begin{tabular}{|l|c|c|}
\hline \multicolumn{1}{|c|}{ Variável } & Desvio padrão da influência & Desvio padrão dependência \\
\hline Aspectos Ambientais - & 7,3 & 5,3 \\
\hline Aspectos Econômicos - 10 & 2,4 & 3,2 \\
\hline Aspectos Econômicos - 2 & 5,2 & 0,0 \\
\hline Aspectos Econômicos - 5 & 3,5 & 5,0 \\
\hline Aspectos Econômicos - 7 & 4,1 & 8,9 \\
\hline Aspectos Econômicos - 9 & 3,9 & 12,5 \\
\hline Aspectos Políticos - 1 & 4,3 & 7,4 \\
\hline Aspectos Políticos - 2 & 5,2 & 6,7 \\
\hline Aspectos Políticos - 4 & 2,8 & 6,8 \\
\hline Aspectos Sociais - 1 & 2,3 & 9,2 \\
\hline Aspectos Sociais - 2 & 5,4 & 10,9 \\
\hline Aspectos Tecnológicos - 3 & 4,1 & 9,8 \\
\hline Aspectos Tecnológicos - 5 & 4,7 & 6,7 \\
\hline Centro Tec.- 2 & 2,3 & 3,5 \\
\hline Entidade de Classe - 1 & 4,6 & 10,3 \\
\hline Órgãos de Fomento à Pesquisa - 1 & 3,6 & 8,1 \\
\hline Órgãos de Fomento à Pesquisa - 2 & 6,0 & 5,0 \\
\hline Universidade - 2 & 4,5 & 10,2 \\
\hline Usinas - 1 & 4,3 & 8,0 \\
\hline Usinas - 2 & 2,9 & \\
\hline Usinas - 3 & 4,3 & \\
\hline
\end{tabular}

\subsubsection{Matriz influência e dependência}

Segue abaixo a matriz de influência e dependência referente a terceira etapa desse estudo: 


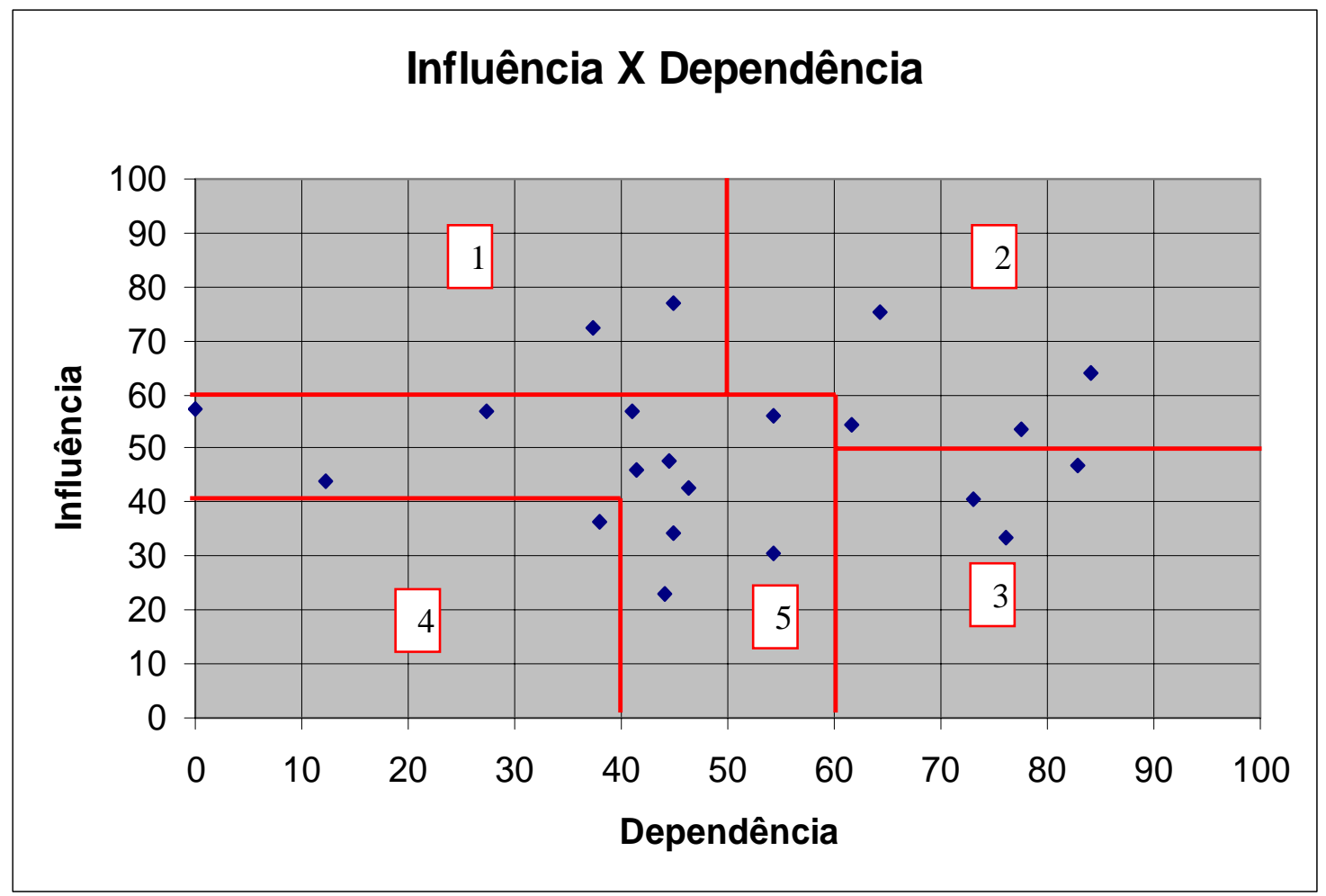

Figura 13 - Matriz de influência e dependência

A consolidação dos pontos plotados no gráfico referente à matriz de influência e dependência é a classificação das variáveis nos respectivos campos da matriz, apontando quais são as variáveis-chaves (setor 1), as variáveis de transmissão (setor 2), as variáveis resultantes (setor 3), as variáveis excluídas (setor 4) e as variáveis meiotermo (setor 5).

O setor 1 representa as variáveis de alta influência e baixa dependência, que condicionam o resto do sistema. O setor 2 representa variáveis de grande influência e dependência. Instabilidade e interferência nas demais variáveis são características intrínsecas. O setor 3 representa variáveis de baixa influência e alta dependência. Influênciam pouco o sistema e não possuem dependência com outras variáveis do sistema. Podem ser desconsideradas. O setor 5 se refere às variáveis de influência e dependência mediana. 


\subsubsection{Tabela final com a classificação das variáveis}

O resultado final da terceira etapa desse estudo está resumido no quadro 7, com o enquadramento das variáveis nos cinco campos da matriz de influência e dependência.

Quadro 7 - Classificação das variáveis nos cinco campos da matriz de influência e dependência

\begin{tabular}{|c|c|c|c|}
\hline Variável & Descrição & Categoria & Setor \\
\hline Aspectos Ambientais - 2 & Agravamento das mudanças climáticas & Tendência & 5 \\
\hline Aspectos Econômicos - 10 & $\begin{array}{l}\text { Alto potencial produtivo de biomassa no } \\
\text { Brasil }\end{array}$ & Tendência & 5 \\
\hline Aspectos Econômicos - 2 & Preço do petróleo & Incerteza & 5 \\
\hline Aspectos Econômicos - 5 & $\begin{array}{l}\text { Logística brasileira favorável para uso } \\
\text { da biomassa (bagaço) }\end{array}$ & Tendência & 5 \\
\hline Aspectos Econômicos - 7 & $\begin{array}{l}\text { Tendência de fusões e aquisições no } \\
\text { setor }\end{array}$ & Tendência & 5 \\
\hline Aspectos Econômicos - 9 & Preço do etanol & Tendência & 3 \\
\hline Aspectos Políticos - 1 & Comoditização do etanol & Incerteza & 2 \\
\hline Aspectos Políticos - 2 & $\begin{array}{l}\text { Criação de subsídios para consolidação } \\
\text { do etanol de segunda geração }\end{array}$ & Incerteza & 1 \\
\hline Aspectos Políticos - 4 & $\begin{array}{l}\text { Aspecto estratégico na diversificação da } \\
\text { matriz energética }\end{array}$ & Incerteza & 5 \\
\hline Aspectos Sociais - 1 & $\begin{array}{l}\text { Adequação do setor às normas } \\
\text { trabalhistas }\end{array}$ & Tendência & 5 \\
\hline Aspectos Sociais - 2 & $\begin{array}{l}\text { Término da queima e da colheita manual } \\
\text { da cana }\end{array}$ & Tendência & 5 \\
\hline Aspectos Tecnológicos - 3 & $\begin{array}{l}\text { Viabilidade de hidrolisar resíduos } \\
\text { agrícolas }\end{array}$ & Incerteza & 3 \\
\hline Aspectos Tecnológicos - 5 & $\begin{array}{l}\text { Pesquisa brasileira em biocombustíveis é } \\
\text { internacionalizada e possuidora de classe } \\
\text { mundial }\end{array}$ & Tendência & 5 \\
\hline Centro de Tecnologia - 2 & $\begin{array}{l}\text { Força o desenvolvimento de coquetéis } \\
\text { enzimáticos mais eficientes }\end{array}$ & Incerteza & 2 \\
\hline Entidade de Classe - 1 & $\begin{array}{l}\text { Força abertura de mercados nacionais e } \\
\text { internacionais para o etanol brasileiro }\end{array}$ & Tendência & 2 \\
\hline Órgãos de Fomento à Pesquisa - 1 & $\begin{array}{l}\text { Financia a pesquisa nos gargalos } \\
\text { técnicos para consolidação do etanol de } \\
\text { segunda geração }\end{array}$ & Tendência & 1 \\
\hline
\end{tabular}




\begin{tabular}{|l|l|l|l|}
\hline Variável & Descrição & Categoria & Setor \\
\hline Órgãos de Fomento à Pesquisa - 2 & $\begin{array}{l}\text { Mudanças genéticas e fisiológicas na } \\
\text { cana para pré-hidrólisar o bagaço na fase } \\
\text { agrícola }\end{array}$ & Tendência & 5 \\
\hline Universidade - 2 & Força a formação de recursos humanos & Tendência & 5 \\
\hline Usinas - 1 & Força a mecanização agrícola & Tendência & 4 \\
\hline Usinas - 2 & $\begin{array}{l}\text { Força a integração da tecnologia de 1.a } \\
\text { geração com a tecnologia de 2.a geração }\end{array}$ & Tendência & 3 \\
\hline Usinas - 3 & $\begin{array}{l}\text { Concorrência pelo bagaço entre etanol } \\
\text { de segunda geração e a bioeletrecidade }\end{array}$ & Tendência & 2 \\
\hline
\end{tabular}

Notoriamente, duas são as variáveis mais importantes para o desenvolvimento do etanol de segunda geração no setor produtivo. O investimento em pesquisa nos gargalos técnicos (Órgãos de Fomento à Pesquisa - 1) e o subsídio governamental para apoiar o desenvolvimento do etanol de segunda geração (Aspectos Políticos - 2). A primeira variável é uma tendência visto que os investimentos em pesquisa são investimentos de longo prazo menos sucetíveis ao comportamento de variáveis incertas como o preço do petróleo (Aspectos Econômicos - 2). A segunda variável, referente aos subsídios governamentais (Aspectos Políticos - 2), é incerta visto que depende de políticas complexas como adição compulsória de etanol de segunda geração no etanol de primeira geração, isenções fiscais produtivas e financiamento de plantas piloto. Entretanto, tais aspectos políticos são absolutamente fundamentais para o desenvolvimento de oferta e demanda em escala industrial para o etanol de segunda geração.

As variáveis do setor 2, variáveis de transmissão, mostram-se claramente dependentes das variáveis do setor 1. A variável "Força o desenvolvimento de coquetéis enzimáticos mais eficientes" (Centro de Tecnologia - 2) é nitidamente dependente da variável-chave de investimento em gargalos técnicos, visto que os coquetéis enzimáticos são um dos principais gargalos técnicos para o desenvolvimento do etanol de segunda geração. As ligadas à abertura de mercado "Força abertura de mercados nacionais e internacionais para o etanol brasileiro" (Entidade de Classe - 1) e "Comoditização do etanol" (Aspectos Políticos - 1), são alguns dos possíveis desdobramentos naturais (no longo 
prazo) de uma política de subsídios para consumo e produção de etanol de segunda geração. Aos moldes do que foi feito no pró-álcool, criando mistura compulsória de etanol na gasolina e financiando o desenvolvimento do setor com taxas de juros diferenciadas. O incremento da concorrência pelo bagaço entre etanol de segunda geração e bioeletrecidade, por sua vez, pode resultar do sucesso das pesquisas em etanol de segunda geração e a criação de mercados iniciais para o seu desenvolvimento. Voltar-se-á a esse ponto mais adiante.

As variáveis do terceiro setor são variáveis de alta dependência. O preço do etanol é uma delas que diferente do preço do petróleo - que não mostrou dependência de outras variáveis aqui estudadas - é dependente da produtividade das usinas, dos investimentos em tecnologia, das políticas de mistura compulsória, entre outros fatores. Entretanto o preço do etanol é regulado pelo governo e mesmo dependendo de mais variáveis é mais previsível que o preço do petróleo. Por ser mais previsível, uma tendência de estabilidade notória, interfere previsivelmente no futuro do etanol de segunda geração. O desenvolvimento do etanol de segunda geração depende do preço do etanol de primeira geração como uma barreira a ser vencida do ponto de vista do custo marginal de produção.

Ao se considerar que há uma tendência futura de integração da tecnologia de primeira e segunda geração nas usinas "Força a integração da tecnologia de 1.a geração com a tecnologia de 2.a geração" (Usinas - 2), o preço do etanol será uma resultante do custo de produção do etanol de primeira geração e do custo marginal de produção adicional do etanol de segunda geração.

Já a viabilidade de hidrolisar outros resíduos agrícolas (Aspectos Tecnológicos - 3) vem compor mais um fator na cesta de elementos que configurarão a oferta de etanol futura e seu respectivo preço, mas é um fator exógeno e incerto. Há pouca pesquisa no Brasil sobre hidrólise de casca de arroz e torta de soja, além de problemas logísticos para viabilizar os custos dessa empreitada. 


\section{CENÁRIOS}

\subsection{Cenários a partir das variáveis-chaves e variáveis dependentes}

Na etapa anterior encontrou-se as variáveis-chaves do sistema estudado: "Financia a pesquisa nos gargalos técnicos para consolidação do etanol de segunda geração" e "Criação de subsídios para consolidação do etanol de segunda geração". Cabe agora usá-las como base para elaborar os cenários pretendidos.

No ítem 2.2.6 desse estudo apresentou-se dois métodos simples propostos por Schwartz e Olgivy, para operacionalizar as regras de interação a fim de se originarem os cenários. Os autores apresentam o método indutivo e dedutivo. Para a cenarização a partir das variáveis-chaves encontradas nesse estudo optou-se pelo método dedutivo. Consiste em construir uma matriz 2 × 2 para as duas variáveis-chaves a fim modelar a estrutura dos enredos.

Adotando-se as duas variáveis-chaves obtidas na seção anterior e aplicando-se o método acima descrito, segue a matriz de cenários para o setor produtivo do etanol de segunda geração tendo em vista o horizonte de 2020.

Variáveis selecionadas:

- Financia a pesquisa nos gargalos técnicos para consolidação do etanol de segunda geração

- Criação de subsídios para consolidação do etanol de segunda geração

Implicações

- Criação artificial de oferta e demanda

- Concorrência pelo bagaço entre etanol de segunda geração e a bioeletrecidade

- Integração da tecnologia de 1.a geração com a tecnologia de 2.a geração (biorefinaria) 


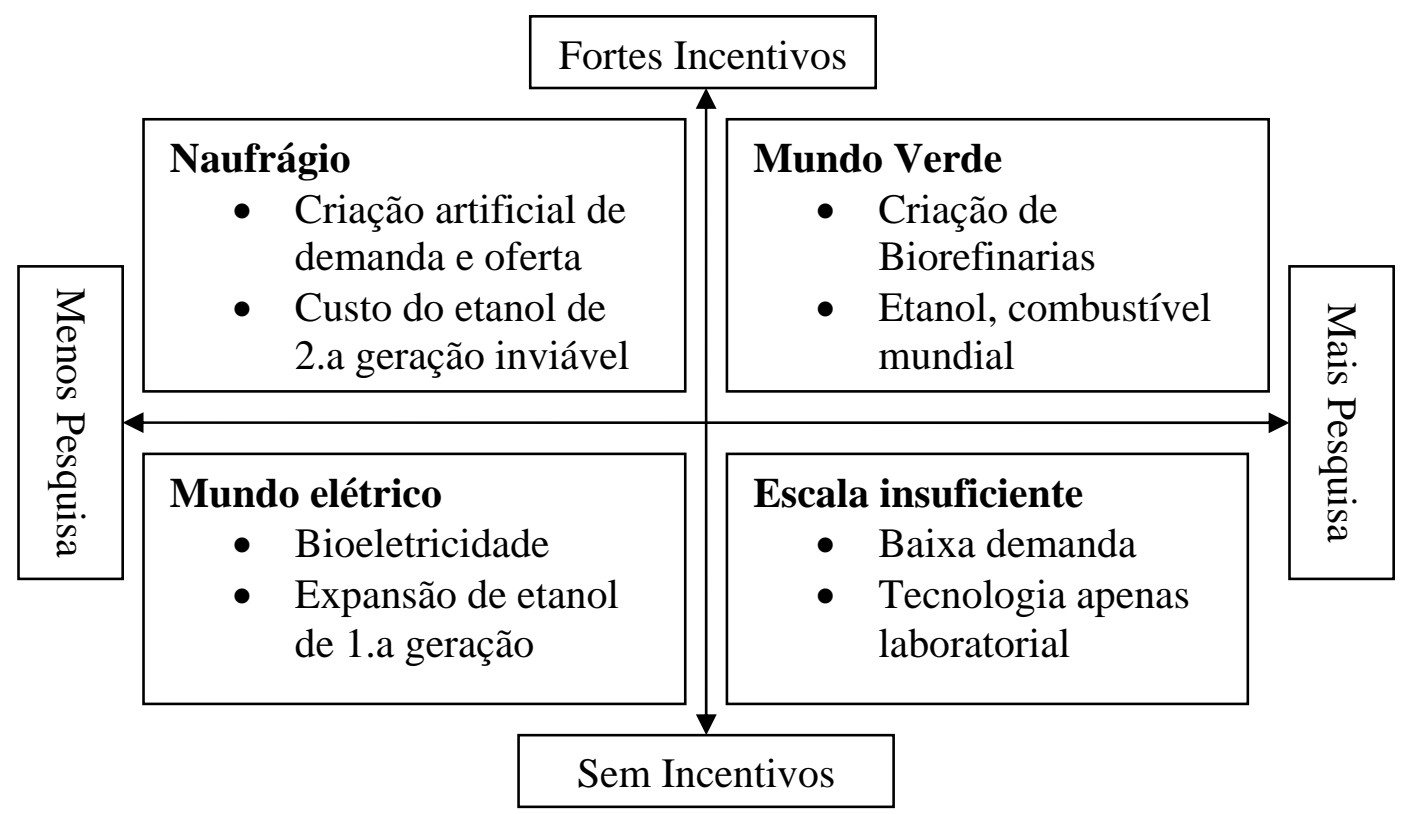

Figura 14 - Cenários para o etanol celulósico em 2020

\subsection{Enredos dos cenários}

Os enredos foram frutos de uma extrapolação lógica que partiu da matriz acima.

Seguindo o modelo do iceberg, também descrito na revisão teórica desse estudo, deduziu-se o comportamento de variáveis-chaves e variáveis dependentes. Com tais interações formou-se uma imagem processual na elaboração de eventos futuros. Os quatro enredos originados seguem adiante.

\subsubsection{Cenário "Naufrágio"}

As pesquisas públicas para o desenvolvimento do etanol de segunda geração não são priorizadas na medida das necessidades. Mostram-se ao longo dos próximos anos insuficientes para tornar o etanol de segunda geração economicamente viável. Os coquetéis enzimáticos não sofrem sufiente barateamento e tornam o preço do litro etanol de segunda geração pouco competitivo. Com isso, as usinas não se sentem encorajadas a investir na tecnologia da fase industrial para a produção de etanol celulósico. Não há integração de processos para primeira e segunda geração de etanol nas usinas. Por outro lado, o governo dá subsídios e investe em plantas semi-industriais, estabelecendo medidas para forçar a criação de um mercado artificial para o etanol celulósico. Há pesados incentivos governamentais mas a curva de apredizagem e de redução dos custos 
para o etanol de segunda geração não se comporta como esperado. As poucas usinas que investiram em tecnologia de segunda geração tendo em vista o mercado criado compulsóriamente pelo governo amargam prejuízos e perda de competitividade.

\subsubsection{Cenário "Mundo Elétrico"}

Os investimentos em tecnologia de segunda geração caem visto que as necessidades de desenvolvimento para tornar o etanol de segunda geração economicamente viável estão muito além das possibilidades concretas. A mesma dificuldade é enfrentada em países estrageiros. O governo brasileiro opta por não criar subsídios para o etanol de segunda geração. Em contrapartida os esforços do governo concentram-se na melhoria das condições produtivas do etanol de primeira geração. O etanol de primeira geração sofre uma grande expansão devido a sua alta competitividade e investimentos privados, principalmente com o aumento de áreas plantadas e capital estrangeiro adquirindo usinas. A economia do país cresce e com ela a necessidade de geração de energia. $\mathrm{O}$ mercado de etanol de primeira geração expande-se interna e externamente comoditização - e as usinas modernizam-se para gerar bioeletricidade do bagaço em caldeiras de alta pressão e sistemas automatizados. O setor privado investe em linhas de transmissão. A eficiência energética da co-geração aumenta a cada dia e São Paulo limpa progressivamente sua matriz energética.

\subsubsection{Cenário "Mundo Verde"}

A pesquisa nos gargalos técnicos é incentivada tanto pelo setor público no que tange à pesquisa básica e aplicada. Com o correr do tempo a indústria absorve o conhecimento científico e transforma-o em aplicação tecnológica. Os coquetéis enzimáticos se tornam mais baratos, pois a demanda por enzimas cresce ano a ano. O governo cria fortes subsídios no sentido de gerar oferta e demanda para o etanol de segunda geração. Para gerar oferta financia plantas piloto. Para criar demanda estabelece adicão de etanol de segunda geração no etanol de primeira geração na forma de mistura compulsória. Com isso cria um mercado interno que cresce com o aumento da capacidade produtiva das usinas. As taxas de juros para o investimento em etanol de segunda geração são subsidiadas e a iniciativa privada tende a assumir mais riscos. A integração da tecnologia de primeira geração e de segunda geração ocorre no setor privado. Em 2020 
as usinas de etanol se transformam em biorefinarias produzindo junto com o etanol bioplásticos, adubo, energia elétrica e ração. Há uma diversificação das atividades canavieiras. Outros países investem no Brasil e devido à alta produtividade o etanol brasileiro é comercializado internacionalmente.

\subsubsection{Cenário "Escala Insuficiente"}

As pesquisas em ciência básica são incentivadas pelo governo de maneira robusta. Os laboratórios criam coquetéis enzimáticos mais eficientes e solucionam boa parte dos gargalos técnicos, mas não há incentivos governamentais para criação de um mercado artificial para o etanol de segunda geração. Não há plantas piloto nem adição compulsória de etanol de segunda geração. Como conseqüência, não há esforços por parte da iniciativa privada para que as tecnologias de escala laboratorial sejam adaptadas para escala industrial. Embora se obtenha um avanço considerável na tecnologia produtiva, o país não construiu uma curva de aprendizagem para o setor produtivo de etanol de segunda geração, como foi feito, por exemplo, com o etanol de primeira geração durante trinta anos. O governo amarga prejuízos. O setor privado tende a migrar para o estado descrito no cenário "Mundo Elétrico" em descompasso com o governo. 


\section{CONCLUSÕES E RECOMENDAÇÕES}

\subsection{Conclusões sobre os cenários produzidos}

A pergunta principal da pesquisa, descrita no tópico 1.4, "Quais seriam os cenários em 2020 para o setor produtivo de etanol paulista tendo em vista o desenvolvimento do etanol de segunda geração?", foi respondida. Os cenários foram obtidos conforme mostrou-se no tópico anterior.

Cabe agora analisar mais aprofundadamente cada um deles. Este tópico segue com a análise parcial de cada cenário e um breve estudo comparativo entre eles.

O cenário "Mundo Verde", parece ser o mais favorável para o Brasil manter a competitividade do setor. Representa a realização do anseio do setor, principalmente entre os pesquisadores que trabalham com etanol. O cenário mostra a consagração de uma nova tecnologia. As conseqüências desse avanço poderiam ser vistas na transformação das usinas atuais em biorefinarias. Uma biorrefinaria pode ser entendida como uma instalação de alta tecnologia que além de combustível produz outros insumos da rota alcooquímica. Uma biorrefinaria produz etanol de primeira geração e de segunda geração, além de outros subprodutos, como energia elétrica, bioplásticos, fertilizantes e ração animal. Caso fosse concretizado, esse cenário traria um salto quantitativo e qualitativo do ponto de vista tecnológico em relação à situação atual. Do ponto de vista econômico, o cenário "Mundo Verde" abriria novas possibilidades comerciais para a indústria ligada à cana-de-açúcar e flexibilizaria a produção fortalecendo a operação. Aparentemente, apresentaria entre os subprodutos produzidos, produtos de alto valor agregado (como bioplásticos, por exemplo).

Se houvesse uma opção por parte do setor privado e do governo em entrar no jogo internacional de criação das próximas matrizes energéticas, considerando-se que o etanol de segunda geração é uma opção válida nesse sentido, então conclui-se que o cenário "Mundo Verde" poderia ser perseguido através da implementação de subsídios e incentivos no sentido de: 
1. Fomentar a pesquisa na fase industrial do etanol de segunda geração em parceria com a iniciativa privada;

2. Gerar demanda por etanol de segunda geração através de mistura compulsória de etanol de segunda geração no etanol de primeira geração;

3. Gerar oferta de etanol de segunda geração através da construção de plantas piloto;

4. Criar financiamentos especiais para bens de capital visando a produção do etanol de segunda geração; e,

5. Desonerar de tributos a comercialização de etanol de segunda geração.

Embora os anseios de parte do setor apontem para o cenário "Mundo Verde", o custo dos investimentos e o esforço científico envolvido para realização desse cenário apresenta-se gigantesco. Nesse contexto, continuar investindo em melhorias na produção do etanol de primeira geração parece ser mais atrativo economicamente do ponto de vista do setor privado. A pergunta que surge nas usinas é: Por que investir em etanol de segunda geração se ainda é possível expandir a eficiência do etanol de primeira geração com menor risco? A resposta a essa pergunta remete à busca do cenário "Mundo Elétrico".

A curto prazo o mais viável para o setor privado parece ser aumentar a eficiência e a produção de etanol de primeira geração usando o bagaço e palha para gerar energia elétrica nas usinas. Ao aproveitar a energia da cana-de-açúcar por completo, valendo-se de um custo já viável nos dias de hoje, o setor poderia expandir suas atividades consideravelmente. Com isso o setor se fortaleceria muito, baratearia os custos através do aumento da eficiência e usaria o bagaço, a palha e as pontas para co-geração de energia elétrica em caldeiras de alta pressão. Ou seja, a opção econômica mais plausível e com menor risco econômico a curto prazo, do ponto de vista do setor privado, parece ser a busca do cenário "Mundo Elétrico", levando os investimentos privados na direção de:

1. Términar a queima na colheita (para manter a biomassa);

2. Mecanizar a fase agrícola (para manter a biomassa);

3. Melhorar genéticamente a cana (aumentar ganhos produtivos); 
4. Desenvolver novos microrganismos fermentadores (aumentar eficiência do processo); e

5. Investir em logística e redes de transmissão.

Entretanto, perseguir o cenário "Mundo Elétrico", no longo prazo, parece ser perigoso do ponto de vista estratégico. Mesmo que o país ganhe no curto prazo, se o Brasil não dominar a tecnologia de segunda geração e os outros países o fizerem, corre-se o risco de em dez anos estarmos competindo com usinas sediadas em outros países tropicais produzindo etanol de primeira geração de maneira integrada ao de segunda geração.

Um problema que o setor nacional poderia enfrentar no longo prazo seria o de haver etanol sendo produzido fora do Brasil valendo-se da conversão fotossintética em outros países tropicais, aliando as tecnologias de primeira e segunda geração. Já existem investimentos estrangeiros para produção de etanol de cana-de-açúcar no continente africano. Corre-se o risco de repetirmos o fracasso do ciclo da borracha do início do século passado neste novo "ciclo da cana-de-açúcar" caso o Brasil não domine essa tecnologia.

Então, para cada um dos dois cenários descritos até aqui pode ser identificado um risco distinto. Primeiro, o risco econômico de se investir no etanol de segunda geração e não conseguir torná-lo competitivo (busca do cenário "Mundo Verde"). Segundo, o risco de não se investir no etanol de segunda geração e de perder competitividade pelo fato de outros países produzirem etanol de cana-de-açúcar de primeira e segunda geração em regiões tropicais (busca do cenário "Mundo Elétrico").

Para lidar com esses dois riscos parece ser necessário assumir uma de duas posições: Ou se investe em pesquisa tecnológica de segunda geração aliada a fortes subsídios governamentais a fim de transformar a pesquisa científica em um produto, ou seja, gerase uma demanda que absorva o resultado dessa pesquisa, ou se investe no aprimoramento da tecnologia de primeira geração com incentivos voltados à geração e distribuição de bioeletricidade voltando os esforços para o mercado interno de energia. No primeiro caso (cenário "Mundo Verde") assume-se um risco econômico, visto que o Estado deve apostar em uma nova tecnologia. No segundo caso (cenário "Mundo Elétrico") os investimentos são direcionados a uma tecnologia consolidada que 
apresenta pouco risco financeiro mas risco estratégico, visto que outros países podem ter sucesso na produção de etanol de segunda geração e dominar o mercado externo.

O que não pode acontecer é o que se vê atualmente, situação na qual se investe muito em pesquisa científica para o etanol de segunda geração com poucos incentivos para que ele se transforme num produto comercializável. Pode-se dizer que no quadro atual existe um forte investimento em pesquisa básica e ausência de subsídios para a consolidação do etanol de segunda geração como produto. Isso nos remeteria ao cenário "Escala Insuficiente" para os próximos dez anos. Claro que deve se considerar as possibilidades concretas de expansão da escala em relação ao atual estágio tecnológico das pesquisas. Mas, aparentemente, investe-se muito em pesquisa mas pouco em geração de escala para essas tecnologias. Diferente dos dois primeiros cenários analisados no parágrafo anterior, não tem sentido perseguir o cenário "Escala Insuficiente".

Hoje há bastante pesquisa laboratorial para etanol de segunda geração e uma falta de subsídios e incentivos para transformar o etanol de segunda geração em produto. Há uma agenda de desenvolvimento científico, e uma agenda de interesses produtivos para o etanol de primeira geração. Mas ainda não há uma agenda para alinhar esses interesses em uma agenda única. Há uma lacuna entre a ciência e a possibilidade de migração do laboratório para a idústria.

Quanto ao cenário "Naufrágio", ele se mostra pouco plausível visto que no Brasil os investimentos em pesquisa que vêm sendo realizadas para o etanol de segunda geração são garantidos por lei através dos órgãos de fomento públicos. Além disso, há uma tendência de aumento dos investimentos em pesquisa e não de redução.

Poderia-se fomentar o aumento de escala para produção de etanol de segunda geração? Dificilmente sem a geração forçada de demanda, a não ser que o custo do etanol de segunda geração fosse baixo o suficiente para que criasse demanda por si próprio. Novamente, no primeiro caso há necessidade de subsídios e incentivos. No segundo caso - geração de demanda por baixo custo - haveria uma necessidade de aposta por parte do setor privado onde o etanol de segunda geração fosse produzido como um produto competitivo. Mas existem poucas condições atuais para que o setor privado 
assuma a tarefa de tornar o etanol de segunda geração competitivo, salvo algumas tentativas de empresas petrolíferas sem conseqüências mercadológicas até agora.

Caso se volte ao passado para analisar a criação da viabilidade mercadológica de um novo combustível, pode-se por em perspectiva o primeiro programa de produção de etanol do Brasil, o Pró-Álcool. O governo brasileiro investiu bilhões de reais durante trinta anos para tornar o etanol de primeira geração competitivo com a gasolina. Esse investimento se deu simultaneamente na forma de fomento à pesquisa e subsídios para produção, principalmente na forma de mistura compulsória de etanol de primeira geração na gasolina. Ou seja, gerou-se demanda.

A figura abaixo mostra a tendência decrescente de preço referente ao etanol de primeira geração em compração com o preço da gasolina:

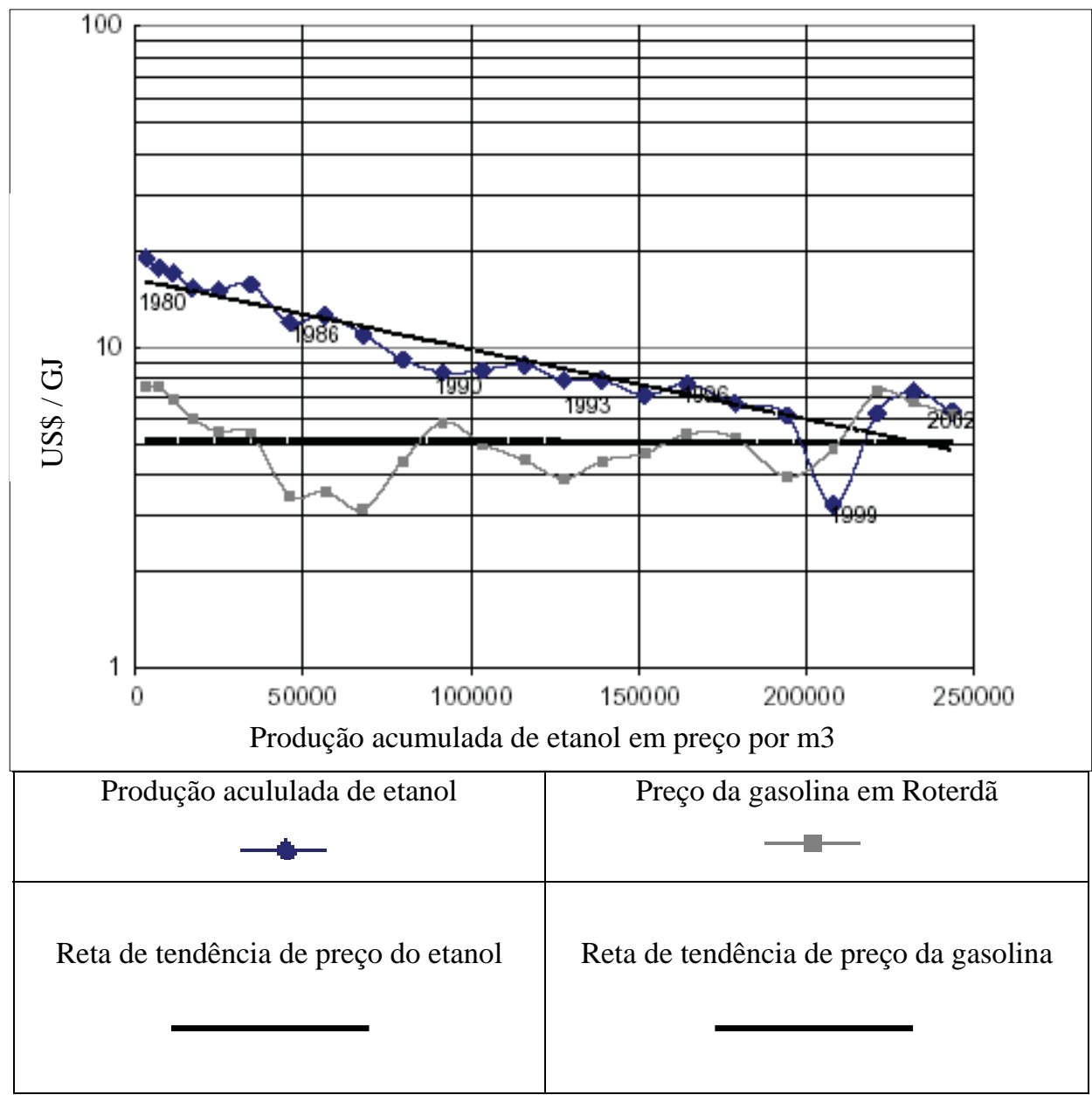

Figura 15 - Valores do etanol pagos ao produtor e preço da gasolina Fonte: Goldenberg, 2004 pg.303 
Ao se analisar o gráfico acima percebe-se que a reta superior (o preço do etanol pago ao produtor) decresceu ao longo dos anos enquanto o preço da gasolina (reta inferior) manteve-se estável. Isso foi resultado de pesquisas laboratoriais aliadas a um aumento gradual da escala produtiva. Tornar o etanol de primeira geração competivo foi tarefa de mais de vinte anos de incentivos governamentais. O etanol de segunda geração, possivelmente também precisará de algum tipo de incentivo além da pesquisa para se tornar uma realidade.

Analisando-se os quatro cenários pode-se perceber que o problema não está na tomada de risco em si, mas está no fato de correr os riscos errados. Ou seja, existem dois cenários que parecem fazer sentido em serem perseguidos: O cenário "Mundo Verde" e o cenário "Mundo Elétrico", um mais voltado para o mercado externo (exportação de etanol), outro voltado para o mercado inerno (suprimento de energia elétrica), cada qual com seus riscos e suas possibilidades de ganhos. O que precisa ser evitado é a realização dos cenários "Naufrágio" e "Escala Insuficiente" pois são dois cenários em que necessáriamente o país perde competitividade. Não há razões para apostar em políticas e incentivos que nos levem a essas duas situações e a política atual parece nos remeter para o cenário de "Escala Insuficiente".

Os investimentos privados parecem nos levar ao cenário "Mundo Elétrico", mas pode-se dizer que existem problemas na política de distribuição, precificação e tributação da energia elétrica no sentido de apoiar a consolidação desse cenário. As linhas de incentivo para expansão da rede de distribuição ainda são um entrave para expandir a geração. A desoneração de impostos para bioenergia elétrica é outro ponto que precisa ser discutido. Onerar energia limpa com impostos não faz sentido por dois motivos: Primeiro, energia limpa significa crescimento da economia rumo a uma matriz sustentável. Segundo, o fato de haver "produtores" de energia desonera a necessidade de investimento por parte do Estado. Portanto, seria preciso melhorar a política energética para que se favoreça o investimento privado na geração de bioeletrecidade.

Quanto à formulação de políticas que nos levem ao cenário "Mundo Verde", pode-se dizer que se faz fundamental o desoneramento de impostos em toda cadeia produtiva a fim de tornar o etanol de segunda geração um produto. Inclui-se aqui produtores de máquinas e equipamentos, insumos, logística entre outros. Seria preciso aumentar a 
escala de produção com a construção de plantas piloto e destinar a produção dessas plantas à mistura compulsória de etanol de segunda geração no etanol de primeira geração.

Encerra-se o tópico lembrando que não é objetivo dessa pesquisa propor estratégias. As análises acima têm um caráter exploratório. A elaboração de estratégias - inclusive sobre a escolha entre perseguir o cenário "Mundo Verde" ou o cenário "Mundo Elétrico" - dependeria de mais repostas, possivelmente daquelas obtidas com a recomendação de pesquisas futuras, apontadas no tópico que segue.

\subsection{Recomendações sobre os cenários produzidos}

No tópico anterior concluiu-se que dois cenários favoráveis podem ser perseguidos em detrimento de dois cenários desfavoráveis. No entanto, tais conclusões abriram espaço para uma série de perguntas importantes. Estas perguntas originadas podem ser vistas como perguntas-base para pesquisas futuras.

As perguntas que surgem nesta etapa do estudo são:

A tecnologia disponível hoje para o etanol de segunda geração já está madura o suficiente para ser subsidiada em escala pré-comercial? A que custo o etanol de segunda geração poderia ser subsidiado?

Responder a esta indagação dupla é fundamental para formulação de estratégias de investimento tanto para as usinas quanto para o governo. Embora o cenário "Mundo Verde" aponte para essa necessidade, é preciso saber qual fôlego financeiro seria suficiente para perseguí-lo nos próximos dez anos.

Como se projetaria a curva de aprendizagem da produção do etanol de segunda geração? Como se comportaria a curva de custo marginal do etanol de segunda geração considerando-se a integração das tecnologias de primeira e segunda geração nas usinas? 
É altamente recomendável uma pesquisa nesse sentido para estimar-se o tempo que levaria para que o etanol de segunda geração se tornasse competitivo e qual seria o tempo de retorno para um investimento produtivo nesse sentido.

O retorno financeiro em se investir no cenário "Mundo Életrico" é maior que o custo dos subsídios necessários para condução ao cenário "Mundo Verde"? Seria possível as usinas investirem rumo ao cenário "Mundo Elétrico" e o governo apostar no cenário "Mundo Verde" e depois se unificar as duas agendas de investimento? Seria possível adquirir tecnologia de segunda geração pronta no futuro?

Essas perguntas são absolutamente fundamentais para o setor produtivo e o governo optarem por qual risco preferem correr. O de investir em pesquisa e subsídios para o etanol de segunda geração ou focar os investimentos na melhoria produtiva do etanol de primeira geração e adquirir a tecnologia de segunda geração posteriormente. Cabe lembrar que, historicamente, adquirir tecnologia parece ser tão complicado quanto desenvolvê-la.

Em face dessas considerações torna-se mais clara a tarefa de decidir por políticas para esses cenários. Como não foi o objetivo dessa pesquisa gerar estratégias, mas sim cenários, ficam aqui algumas recomendação para estudos futuros na forma dessas perguntas.

\subsection{Conclusões e recomendações sobre a aplicação do método de geração de variáveis-chaves}

O objetivo secundário desse estudo foi testar um método de geração de variáveis-chaves no setor produtivo de etanol, conforme descrito no ítem 1.4. A pergunta de pesquisa ligada a este objetivo foi:

Como o método de geração de variáveis-chaves usado na metodologia desse estudo se comportará na tarefa de gerar cenários para setor produtivo de etanol? 
O método se mostrou adequado para elaborar os cenários desejados. As etapas previstas na metodologia de geração de variáveis-chaves para elaboração de cenários foram testadas e realizadas no setor produtor de etanol e os dados se mostraram consistentes.

Outro aspecto importante a ser citado foi a utilização das variáveis-chaves para elaboração dos cenários em si, com seus enredos correlatos. As duas variáveis-chaves encontradas articularam-se de forma satisfatória no modelo de cenarização empregado. Recomenda-se fortemente a construção de mais cenários com as variáveis encontradas, particularmente explorando matrizes de cenários com variáveis de incerteza.

O método de geração de variáveis-chaves foi testado no setor produtivo de etanol com sucesso. 


\section{REFERÊNCIAS}

ARAÚJO, Luis César G. Teoria Geral da Administração: aplicação e resultados nas empresas brasileiras. Ed Atlas, SP, 2004.

AYRES, R. U e AXTELL, R. Foresight as a Survival Characteristic: when (if ever) does the long view pay? Technological Forecasting and Social Change, vol. 51, n.3, pg. 209-235, 1996.

BELL, Wendell e OLICK, Jeffrey K. An Epistemology for the Futures Field. Futures, April, 1989, pg115-135.

BOAVENTURA, João Mauricio Gama. Um Modelo para Validar e Aprimorar a Visão de Futuro: Um Estudo no Setor de Automação Comercial. Tese de Doutorado. São Paulo: FEA USP, 2003.

BOAVENTURA, João Maurício Gama, FISCHMANN, Adalberto Américo \& COSTA, Benny Kramer. Cenários: Metodologias e Métodos de Construção. In: Estratégia: direcionando negócios e organizações [organizadores: Benny Kramer Costa, Martinho Isnard Ribeiro de Almeida]. Editora Atlas, São Paulo, 2005.

BOAVENTURA, João Maurício Gama, FISCHMANN, Adalberto Américo \& COSTA, Benny Kramer. Desenvolvimento de um método para geração de variáveis-chaves de cenários: Um ensaio no setor de automação comercial no Brasil. In: Estratégia Contemporânea: Internacionalização, cenários e redes/ [organizadores Benny Kramer Costa, Martinho Isnard Ribeiro de Almeida]. - Campinas, SP: Akademika Editora, 2008.

BOAVENTURA, João Maurício Gama and FISCHMANN, Adalberto Américo. Is your vision consistent? A method for checking, based on scenario concepts. Futures n.40

Pg.597-612, 2008.

BONTEMPO, Mary Tsutsui. Análise comparativa dos métodos de construção de cenários estratégicos no planejamento empresarial. Tese de Mestrado. São Paulo, FEA/USP. 2000.

BÖRJESON, Lena et all. Scenario types and techniques: Towards a user's guide. Futures, n.38 pg.723-739, 2006.

BRADFIELD, Ron et all - The origins and evolution of scenario techniques in long range business planning. Futures, vol.37, pg. 795-812, 2005.

BUCKERIDGE, M. S. (2009) - Routes to cellulosic ethanol: biotecnological solutions for sustainable improuvement of cell wall degradation. Workshop on hydrolysis route for cellulosic ethanol from sugarcane. CTBE, Unicamp, 2009.

CHERMACK, Thomas J. - Improving decision-making with scenario planning. Futures, vol.36, pg. 295-309, 2004. 
CLAUSEWITZ, Karl von. On war. Translated from the German by O.J. Matthijs Jolles. New York : The Modern Library, 1943.

COSTA, Eliezer A. Gestão Estratégica. São Paulo: Saraiva, 2002.

Collins Language on-line dictionary. Disponível em: www.collinslanguage.com, 30/maio/2009.

CRESWELL, John W. Qualitative Inquiry and Research Design. Thousand Oaks, California: Sage Publications, 1998.

DREBORG, Karl H. Essence of Backcasting. Futures, vol.28, n.9, 1996, pg.813-828.

FAYOL, Henri. Administração Industrial e Geral. 10.ed. São Paulo : Atlas, 1990.

FERREIRA, Aurélio Buarque de Holanda. Dicionário Aurélio Básico da Língua Portuguesa. Editora Nova Fronteira, 1995.

GIL, Antônio Carlos. Métodos e técnicas de pesquisa social. São Paulo: Atlas, 1999.

GEORGANTAS, Nicolas C. e ACAR, Willian. Scenario-Driven Planning: Learning to Manage Strategic Uncertainty. Westport, Connecticut: Quorum Books, 1995.

GODET, Michel. From Forecasting to 'La Prosoective'. A New Way of Looking at Futures. Journal of Forecasting Vol 1, n.3, pg.293-301, 1982.

GODET, Michel. From Antecipation to Action. Paris, UNESCO Publishing, 1993.

GODET, Michel e ROUBELAT, Fabrice. Creating the future: The use and misuse of scenarios. Long Range Planning, v. 29, n.2 pg. 164-171, 1996.

GOODE, Willian J. e HATT, Paul K. Métodos em Pesquisa Social. 4.a ed., São Paulo: Companhia Editora Nacional, 1972.

GOLDENBERG J. - Programa de bioenergia do Estado de São Paulo IN Conferência nacional de bioenergia, 2007, São Paulo. ORG. Francisco Costa. USP - CCS Coordenadoria de comunicação social, 2007.

GOLDENBERG J., Coelho, S. T., Nastaric, P. M., Lucon, O. - Ethanol learning curve the brazilian experience. Biomass and Bioenergy, Vol.26 pg.301-304, 2004.

HEIDJEN, Kees van der. Planejamento de Cenários, a arte da conversação estratégica, Trad. Carlos Alberto Silveira Netto Soares e Nivaldo Montingelli Jr. Porto Alegre: Bookman, 2004.

HOUAISS, Antônio. Dicionário Eletrônico Houaiss da Língua Portuguesa, versão 2.0a. Editora Objetiva, 2007. 
HUSS, Willian R. e HONTON, Edward J. Scenario Planning - What Style Should You Use?. Long Range Planning, Vol. 20, No. 4, pg. 21-29, 1987.

JANTSCH, Erich. Technological Forecasting in Perspective. OCDE - Organization for Economic Co-operation and Development, Paris, 1969

JOSEF, Henry Junior. Tecnologia de Motores Flexíveis IN Biocombustíveis no Brasil, Realidades e Perspectivas. PNUD e Ministério das Relações Exteriores do Brasil, Arte Impressa Editora Gráfica, 2007.

LASER, M.; Jin, H.; JAYAWARDHARA, K.; DALE, B. E.; LYND, L. R. Projected mature technology scenarios for convertion of cellulosic biomass to ethanol with coprodution of themochemical fuel, power and/or animal feed protein. Draft of paper 7 in fothcoming special issue of Biomass Bioenergy, 2008.

LEITE, Rogério Cézar de Cerqueira - O biocombustível no Brasil. Autor secundário: Manoel, Régis L. V. Leal. Revista Novos Estudos CEBRAP, N. 78, julho 2007, pg. 1521.

MAJOR, Edward, ASCH, David \& CORDEY-HAYES, Martyn. Foresight as a Core Competence. Futures, vol.33, 2001, pg.91-107.

MAXIMIANO, Antônio Amaru. Teoria Geral da Administração: da revolução urbana à revolução digital. Ed Atlas, 2002.

MASON, David H. Scenario-based planning: decision model for the learning organization. Planning Review, vol.22, mar/apr, 1994, pg. 6-11.

Scenario Planning: Mapping the paths to the desired future. In Lian Fahey \& Robert M. Randall (Orgs). Learning from the future: competitive foresight scenarios, (p.109-121). New York: John Wiley \& Sons, Inc., 1998

MASINI, Eleonora Barbieri \& VASQUEZ, Javier Medina - Scenarios as Seen from a Human and Social Perspective. Technological Forecasting and Social Change, Vol. 65, pg. 49-66, 2000.

MILLETT, Stephen M. Battelle's Scenario Analysis of a European High Tech Market. Planning Review, vol.20, n.2, 1992, pg.20-23.

MITROFF, Ian I. \& EMSHOFF, James R. On Strategic assmption-making: a dialetical aproach to policy and planning. Academy of management Review, vol.4, n.1, pg.1-12, 1979.

My Etmology Dictionary. Disponível em: http://www.myetymology.com, Acesso em: 30/maio/2009.

NOTTEN, Philip, W. F. van, Jan Rotmans, Marjolein B. A. van Asselt e Dale S. Rothman. An Updated scenario typology. Futures, n.35, 423-443, 2003. 
PORTER, Michael E Competitive Advantage. New York: Free Press, 1985.

POSTMA, Theo J.B.M. e LIEBL, Franz - How to improve scenario analysis as a strategic management tool? Technological Forecasting \& Social Change Vol.72, Pg. 161-173, 2005.

RINGLAND Gill. Scenario Planning: managing for the future. Chichester: John Wiley \& Sons Ltd. 1998.

RINGLAND, Gill. Scenario Planning, Managing for the Future. Ed. Jonh Wiley \& Sons, 2006.

ROSSEL, C. E. V., PRADELLA, J. G. C., GÓMEZ, E. O., SQUINA, F. M.. (2009) Pilot plant for processes development - PPDP - Sugarcane Bagasse and Trash Convertion to Bioethanol. Workshop on hydrolysis route for cellulosic ethanol from sugarcane. Poster Session for Research Group Presentations Abstracts. CTBE, Unicamp, 2009.

SACHS, I. - Da civilização do petróleo a uma nova civilização verde. http://www.scielo.br/scielo.php?script=sci_arttext\&pid=S0103-40142005000300014 — Revista de Estudos Avançados da USP, vol.19 no.55 São Paulo Sept./Dec. 2005

SCHWARTZ, Peter. A Arte da Previsão. São Paulo, Editora Página Aberta Ltda, 1995.

SCHWARTZ, Peter. A Arte da visão de longo prazo. São Paulo: Nova Cultural, 2000.

SCHWARTZ, Peter. and OLGIVY. James, A. Ploting Your Scenarios. Plotting your scenarios. In: Learning from the future: Competitive foresight scenarios

[organizadores, Liam Fahey and Robert M. Randall]. Editora Wiley, New York, 1998.

SHOEMAKER, Paul J. H. Multiple scenario development: its conceptual and behavioral foudation,. Strategic Management Journal, v.14, pg.193-213, 1993.

SHOEMAKER, Paul J. H. Scenario Planning: a tool for strategic thinking. Sloan Management Review, Winter, 1995, pg.25-40.

SLAUGHTER, Richard A. Foresight beyond strategy. Long Range Planning, 29, pg.156-63, 1996.

SUNZI. A Arte da Guerra - Edição Bilíngue. Trad. Adam Sun. Editora Conrad, São Paulo, 2006.

THOMPSON, Susan - Biotechnology - Shape of Things to Come or False Promise?

Futures. August 1986, pg. 514-525.

TILLEY, Fiona, 2 FULLER, Ted. Foresighting Methods and their Role in Researching Small Firms and Sustainability. Futures, vol.32, 2000, pg.149 - 161.

VAN VUGHT, F. A. Pitfalls of Forecasting. Futures, April, 1987, pg.184-196. 
WACK, Pierre. Scenarios: Uncharted Waters Ahed. Harvard Business Review, september-october, 1985, pg.73-89.

WILSON, Ian. Mental Maps of the Future: An Intuitive Logics Approach to Scenarios. In Lian Fahey \& Robert M. Randall (Orgs). Learning from the future: competitive foresight scenarios, p.81-108. New York: John Wiley \& Sons, Inc., 1998

ZACCHI (2009) - Advances in $2^{\text {nd }}$ G. bioethanol production and possibilities for integration with $1^{\text {st }} \mathrm{G}$. bioethanol. Workshop on hydrolysis route for cellulosic ethanol from sugarcane. CTBE, Unicamp, 2009. 
ANEXO 1 - Lista de usinas de etanol do Estado de São Paulo

Lista de usinas associadas da UNICA - União da Indústria da Cana de Açúcar no Estado de São Paulo:

Abengoa Bioenergia São Luiz S.A.

Água Bonita Ltda.

Alcídia

Alcoeste Destilaria Fernandópolis S.A.

Aralco S.A. Indústria e Comércio

Aralco S.A. Indústria e Comércio - Figueira

Aralco S.A. Indústria e Comércio - Generalcool

Balbo - Santo Antonio S.A.

Balbo - São Francisco S.A.

Batatais S.A. Açúcar e Álcool (Batatais)

Batatais S.A. Açúcar e Álcool (Lins)

Bazan S.A.

Bazan S.A. - Bela Vista S.A.

Benalcool Açúcar e Álcool S.A.

Brenco - Companhia Brasileira de Energia

Renovável

Central Paulista Açúcar e Álcool Ltda.

Cerradinho Açúcar e Álcool S.A.

Cerradinho Açúcar e Álcool S.A. (Potirendaba)

CEVASA - Central Energética Vale do Sapucaí

Clealco Açúcar e Álcool S.A. (Clementina)

Clealco Açúcar e Álcool S.A. (Queiroz)

Cocal I - Com. Ind. Cana-de-Açúcar e Álcool

Ltda.

Cocal II - Com. Ind. Cana-de-Açúcar e Álcool

Ltda.

Colombo S.A. Açúcar e Álcool

Colombo S.A. Açúcar e Álcool (Palestina)

Cosan S.A. Indústria e Comércio (Bom Retiro)

Cosan S.A. Indústria e Comércio (Costa Pinto)

Cosan S.A. Indústria e Comércio (Da Serra -

Ibaté)

Cosan S.A. Indústria e Comércio (Diamante)

Cosan S.A. Indústria e Comércio (Junqueira)

Cosan S.A. Indústria e Comércio (Mundial)

Cosan S.A. Indústria e Comércio (Rafard)

Cosan S.A. Indústria e Comércio (Santa Helena)

Cosan S.A. Indústria e Comércio (São

Francisco)

Da Barra S.A. Açúcar e Álcool (Corona -

Bonfim)

Da Barra S.A. Açúcar e Álcool (Da Barra)

Da Barra S.A. Açúcar e Álcool (Destivale)

Da Barra S.A. Açúcar e Álcool (Dois Córregos)

Da Barra S.A. Açúcar e Álcool (Gasa)

Da Barra S.A. Açúcar e Álcool (Ipaussu)

Da Barra S.A. Açúcar e Álcool (Nova Tamoio)

Da Barra S.A. Açúcar e Álcool (Univalem)

Della Colleta Bioenergia S.A.

Equipav S.A. Açúcar e Álcool

Equipav S.A. Açúcar e Álcool - Biopav
Ester S.A.

Farias - São José S.A. Açúcar e Álcool

Ferrari Agroindústria S.A.

Furlan S.A.

Furlan S.A. (Avaré)

Guarani S.A. (Andrade)

Guarani S.A. (Cruz Alta)

Guarani S.A. (São José)

Guarani S.A. (Severínia)

Guarani S.A. (Tanabi)

Guariroba Ltda.

Iacanga de Açúcar e Álcool Ltda.

Ipiranga de Açúcar Álcool Ltda.

Ipiranga de Açúcar Álcool Ltda. (Мococa)

Irmãos Malosso Ltda.

Itaiquara de Açúcar e Álcool S.A.

Moema Açúcar e Álcool Ltda.

Nardini Agroindustrial Ltda.

Noroeste Paulista Ltda.

Nova América S.A. - Agroenergia

Nova América S.A. - Agroindustrial (Maracaí)

Ouroeste Açúcar e Álcool Ltda.

Paraguaçu Ltda. (Paralcool)

Paraíso Bioenergia Ltda.

Pedra Agroindustrial S.A. (Buriti)

Pedra Agroindustrial S.A. (Ibirá)

Pedra Agroindustrial S.A. (Ipê)

Pedra Agroindustrial S.A. (Serrana)

Pioneiros Bioenergia S.A. (Sud Mennucci)

Pitangueiras Açúcar e Álcool Ltda.

Sanagro - Companhia Brasileira de Açúcar e

Álcool (ICEM)

Santa Adélia S.A.

Santa Adélia S.A. (Interlagos)

Santa Cruz S.A. Açúcar e Álcool

Santa Fé S.A.

Santa Inês

Santa Lúcia S.A.

Santa Maria - J. Pilon S.A. Açúcar e Álcool

Santa Rosa Ltda.

São Domingos Açúcar e Álcool S.A.

São João Açúcar e Álcool S.A.

São José da Estiva S.A. Açúcar e Álcool

São Luiz (Ourinhos)

São Manoel S.A.

São Martinho S.A.

São Martinho S.A. (Boa Vista)

São Martinho S.A. (Iracema)

Unidade Continental - Colômbia

Unidade Cresciumal - Leme SP 
Unidade Jardest - Jardinópolis

Unidade MB - Morro Agudo

Unidade Santa Elisa - Sertãozinho SP

Unidade São Carlos - Jaboticabal SP

Unidade Vale do Rosário - Morro Agudo

Vertente Ltda.

Viralcool I Açúcar e Álcool Ltda.

Viralcool II Açúcar e Álcool Ltda. (Castilho)
Virgolino de Oliveira S.A. (Catanduva)

Virgolino de Oliveira S.A. (Itapira)

Virgolino de Oliveira S.A. (José Bonifácio)

Virgolino de Oliveira S.A. (Monções)

Vista Alegre

Zanin Açúcar e Álcool Ltda.

Zilor - Barra Grande de Lençóis S.A.

Zilor - Quatá S.A.

Zilor - São José (Macatuba)

Lista das usinas associadas da Copersucar S/A - Cooperativa de Produtores de Cana-deaçúcar no Estado de São Paulo:

Usina Batatais S.A. - Açúcar e Álcool - Filial

Pedra Agroindustrial S.A.

Virgolino de Oliveira S.A. - Açúcar e Álcool

COCAL - Comércio Indústria Canaã Açúcar e Álcool Ltda.

COCAL - Comércio Indústria Canaã Açúcar e Álcool Ltda.

Pedra Agroindustrial S.A.

Ferrari Agroindústria S.A. - Açúcar e Álcool

Usina Açucareira Furlan S.A.

Usina Açucareira Furlan S.A.

Usina Iacanga de Açúcar e Álcool Ltda.

Pedra Agroindustrial S.A.

Pedra Agroindustrial S.A.

Usina Ipiranga de Açúcar e Álcool Ltda. - Matriz

Usina Ipiranga de Açúcar e Álcool Ltda. - Filial

Cia. Agrícola Usina Jacarezinho

Açucareira Virgolino de Oliveira S.A.

Usina Batatais S.A. - Açúcar e Álcool - Filial

Destilaria Melhoramentos S.A.

Açucareira Virgolino de Oliveira S.A.

Virgolino de Oliveira S.A. - Açúcar e Álcool

Pioneiros Bionergia S.A.

Usina Santa Adélia S.A.

Usina Santa Adélia S.A.

Usina Santa Lúcia S.A.

J. Pilon S.A. - Açúcar e Álcool

Usina Santo Antônio S.A.

Usina São Francisco S.A.

Usina São José da Estiva S.A. - Açúcar e Álcool

Usina São Luiz S.A.

Usina Açucareira São Manoel S.A.

Usina Barra Grande de Lençóis S.A.

Açucareira Quatá S.A.

Açucareira Zillo Lorenzetti S.A. 


\section{ANEXO 2 - Lista dos especialistas consultados}

Alfred Schwarcs - Consultor sênior para etanol de segunda geração da ÚNICA -União da Indústria da Cana de Açúcar, entidade de classe da indústria da cana-de-açúcar.

Carlos E. V. Rossell - Pesquisador do CTBE, Centro de Tecnologia do Bioetanol e professor do departamento de Engenharia Química da Unicamp - Universidade Estadual de Campinas.

Cleber Aguiar - Gerente de produção do Grupo São Manoel, usinas de etanol e açúcar do Estado de São Paulo.

Benjamin Rærup Knudsen - Gerente de P\&D da Novozymes Latin América Ltda.

Jaime Finguehut - Gerente Técnico do CTC, Centro de Tecnologia Canavieira.

José Américo Rubiano - Diretor da J. A. Rubiano Consultores Assossiados, empresa de consultoria na área financeira para indústria sucroenergética

Maitê de Souza Sandoval - Diretora Técnica da Secretaria do Meio Ambiente do Estado de São Paulo com contribuição da equipe técnica: Carolina Roberta Alves de Matos, Juliana G. Roscito, Luiz Felipe Lomanto Santa Cruz.

Marcos Buckeridge Diretor do programa de bioenergia (BIOEN) da FAPESP - Fundo de Amparo à Pesquisa do Estado de São Paulo.

Marcos de Oliveira - Editor de tecnologia da Revista Pesquisa Fapesp.

Paulo Augusto Soares, Gerente do projeto DHR - Dedine Hidrólise Rápida, da DEDINE empresa fabricante de equipamentos pesados e plantas industriais para o setor sucroenergético.

Pedro Luiz Fernandes - Presidente da Novozymes Latin América Ltda., multinacional dinamarquesa para fabricação de enzimas industriais. 
Pedro Paranhos - Gerente comercial da Copersucar - Cooperativa de Produtores de Cana-de-açúcar.

Rafael Araújo Borges - Pesquisador da Prozyn Biosolutions, empresa brasileira fabricante de insumos para a indústria de etanol. Com o apoio de Fernando Uema, Gerente comercial da Prozyn Biosolutions.

Ricardo Viegas - Diretor do programa de etanol do Governo do Estado de São Paulo na Secretaria do Meio Ambiente.

Silvia Maria Guerra Molina - Professora livre-docente do Laboratório de Ecogenética de Resíduos Agroindustriais e Ecologia Humana do Departamento de Genética da ESALQ.

Notas:

Na segunda etapa da coleta de dados Maitê Sandoval substituiu Ricardo Viegas. Eder Novozymes substituiu Pedro Luiz Fernandes. Pedro Paranhos substituiu Alfred Schwarcs.

Na terceira etapa da coleta de dados Silvia Maria Guerra Molina substituiu Carlos E. V. Rossell. Rafael Araújo Borges substituiu Benjamin Rærup Knudsen. 


\section{ANEXO 3 - Instrumentos de coleta dos dados}

ETAPA 1 - Questionário de identificação das variáveis.

Prezado (a) Senhor(a),

Esta pesquisa tem o propósito de construir cenários sobre o desenvolvimento do etanol de segunda geração no setor produtivo. Para tanto, são necessárias três etapas de entrevistas (não necessáriamente com os mesmos entrevistados), sendo esta a primeira etapa. Aqui se procurará identificar as variáveis que influenciam o desenvolvimento do etanol de segunda geração (celulósico). Deseja-se identificar dois grupos de variáveis: àquelas referentes aos atores e ao macroambiente em que estão envolvidos.

BLOCO 1 - Identificação de Atores

É apresentada uma lista de potenciais atores com os quais sua organização se relaciona. Nem todos os itens mencionados influenciam o desenvolvimento do etanol de segunda geração, podendo o especialista sugerir outros atores que não constem na lista:

Relação de potenciais atores:

- Centro de tecnologia

- Universidades

- Órgão de fomento de pesquisa

- Fabricante de insumos

- Entidade de classe da indústria da cana

- Usina de etanol

- Governo

- Fabricante de equipamentos

- Imprensa especializada

- Empresa de consultoria em financiamento

- Empresa de consultoria em Engenharia

- Centro de pesquisas econômicas

- Instituição financeira

- Empresa pública do setor sucroenergético

- Órgãos de Patentes

BLOCO 2 - Características dos atores:

Para cada um dos atores apontados acima, as seguintes informações são solicitadas:

a) Os propósitos básicos dos atores;

b) Os benefícios que os atores podem vir a ter;

c) Os recursos controlados pelos atores (materiais, políticos, informacionais)

d) Conhecimento distintivo;

e) Compromissos legais ou de outras naturezas; e

f) Relacionamento com outros atores (autoridade e credibilidade).

BLOCO 3 - Premissas dos atores 
Com base nas características acima apontadas, procure definir para cada ator uma ou mais forças de influência no ambiente.

BLOCO 4 - Identificação das Variáveis do Macroambiente

Segue uma lista sugestiva sobre os elementos do macroambiente. Acrescente outros elementos que julgar pertinente e relacione, para cada elemento, uma ou mais premissas sobre o ambiente de estudo.

a) Aspectos tecnológicos que influenciam o seu setor;

b) Aspectos sociais que influenciam o seu setor;

c) Aspectos econômicos que influenciam o seu setor ; e

d) Aspectos políticos que influenciam o seu setor. 
ETAPA 2 - Questionário de avaliação das variáveis do ambiente

Prezado (a) Senhor(a),

O propósito dessa etapa da pesquisa é qualificar as variáveis que influenciam o setor produtivo de etanol a partir do desenvolvimento do etanol de segunda geração. Mais especificamente, procura qualificar as variáveis em duas dimensões:

a) Em relação ao grau de importância no setor

b) Quanto ao grau de incerteza

BLOCO 1 - Qualificação de importância das variáveis:

Para cada uma das variáveis relacionadas nos quadros abaixo, procure atribuir valores em relação à uma escala de -5 a 5, conforme o que segue:

(-5) - variável de muito baixa importância no ambiente;

(-4) ... (-1) - variáveis intermediárias;

(0) - variável de média importância no ambiente;

(1) ... (4) - variáveis intermediárias; e

(5) - variável de muito alta importância no ambiente.

$-5$

0

BLOCO 2 - Qualificação da incerteza das variáveis.

Para cada uma das variáveis abaixo procure atribuir valores quanto ao quesito incerteza/certeza, conforme uma escala de -5 a 5 , conforme segue:

(-5) - variável de muito baixa incerteza no ambiente;

(-4) ... (-1) - variáveis intermediárias;

(0) - é provável;

(1) ... (4) - variáveis intermediárias; e

(5) - variável de muito alta incerteza no ambiente.

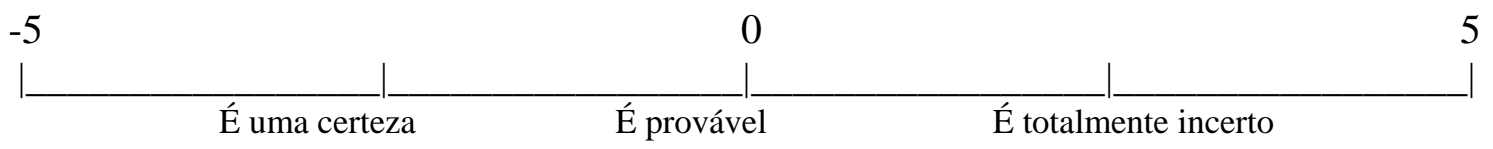

Tabela para coleta de dados da segunda etapa: 
Centro de tecnologia

Força o desenvolvimento de microorganismos mais eficientes

Força o desenvolvimento de coquetéis enzimáticos mais eficientes

Força o desenvolvimento de métodos mais eficientes de tratamento do bagaço

Força a elaboração de simuladores de usinas de etanol de segunda geração

Universidades

Força a criação de centros de pesquisa

Força a formação de recursos humanos

Órgão de fomento de pesquisa

Financia a pesquisa nos gargalos técnicos para consolidação do etanol de segunda geração

Mudanças genéticas e fisiológicas na cana para pré-hidrólisar o bagaço na fase agrícola

Fabricante de insumos

Força diminuição do custo de produção das enzimas através do aumento da escala produtiva

Entidade de classe da indústria da cana

Força abertura de mercados nacionais e internacionais para o etanol brasileiro

Alinha estratégias de pesquisa segundo necessidades da indústria

Usina de etanol

Força a mecanização agrícola

Importância

Incerteza

Força a integração da tecnologia de 1.a geração com a tecnologia de 2.a geração

Concorrência pelo bagaço entre etanol de segunda geração e a bioeletrecidade

Eletrificação e automação do sistema de produção atual

Empresa pública do setor sucroenergético

Força o desenvolvimento de equipamentos para fase agrícola

Governo

Força a construção de plantas de etanol de segunda geração em escala pré-industrial

Força equilíbrio entre oferta e demanda de etanol no mercado interno

Força a construção de alcooldutos e a utilização da infra-estrutura petroquímica

Fabricante de equipamentos

Desenvolve e fornece equipamentos para tratamento do bagaço e produção de enzimas

\begin{tabular}{|l|l|l|l|}
\cline { 3 - 4 } \multicolumn{2}{|c|}{} & Importância & Incerteza \\
\hline & & & \\
\hline & 1 & & \\
\hline & 2 & & \\
\hline & 3 & & \\
\hline & 4 & & \\
\hline
\end{tabular}




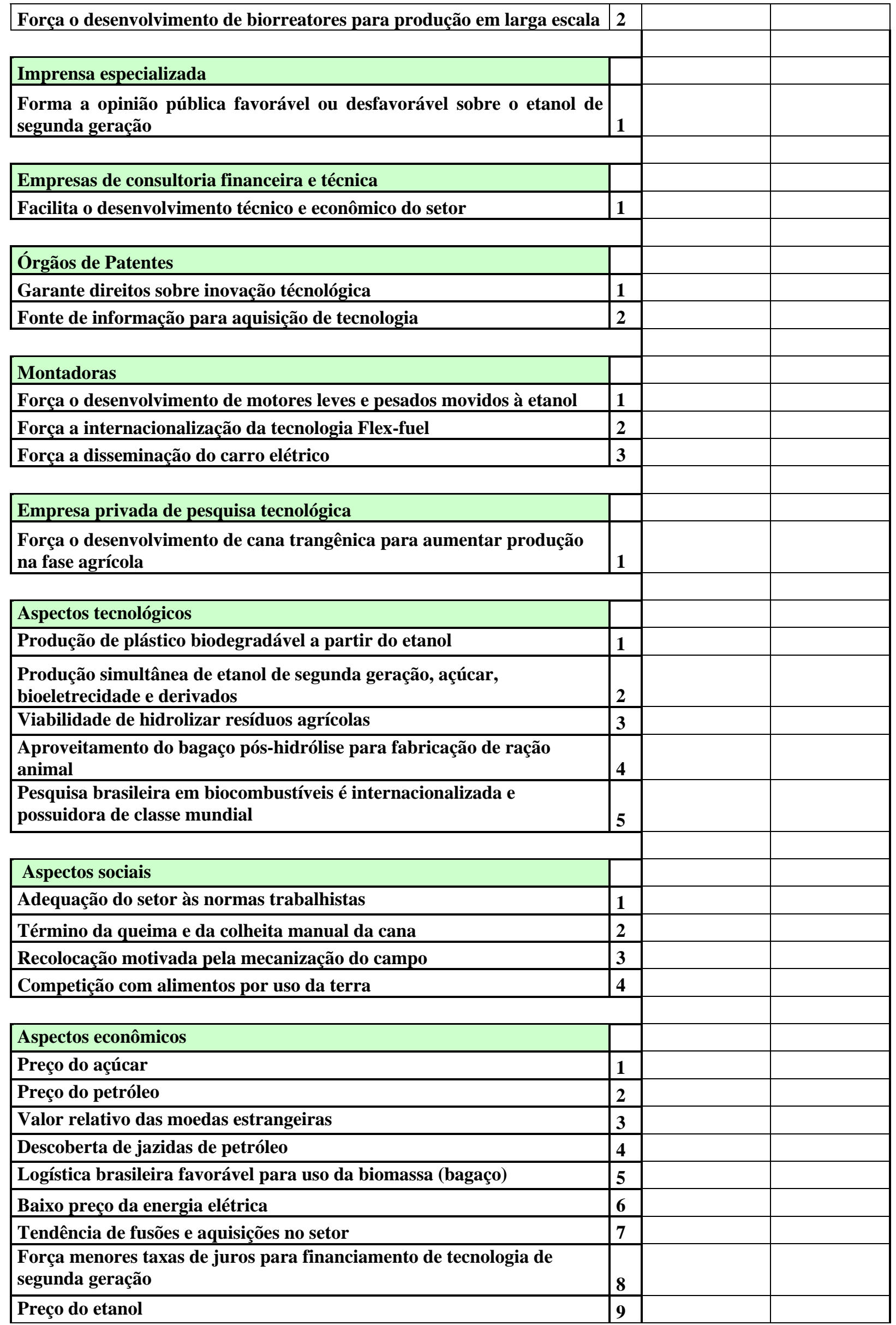




\begin{tabular}{|l|l|l|l|}
\hline \multicolumn{2}{|l|}{ Alto potencial produtivo de biomassa no Brasil } & \multicolumn{1}{|l|}{} & \\
\hline \multicolumn{2}{|l|}{} & & \\
\hline Aspectos políticos & & & \\
\hline Comoditização do etanol & 1 & & \\
\hline Criação de subsídios para consolidação do etanol de segunda geração & 2 & & \\
\hline $\begin{array}{l}\text { Ausência de tarifas alfandegárias nos EUA para o açúcar produzido no } \\
\text { nordeste brasileiro }\end{array}$ & 3 & & \\
\hline Aspecto estratégico na diversificação da matriz energética & 4 & & \\
\hline Protecionismo estrangeiro & 5 & & \\
\hline & & & \\
\hline f) Aspectos Ambientais & & & \\
\hline $\begin{array}{l}\text { Diminuição do impacto ambiental promovido pelo etanol de segunda } \\
\text { geração }\end{array}$ & 1 & & \\
\hline Agravamento das mudanças climáticas & 2 & & \\
\hline Uso sustentável da água & 3 & & \\
\hline Biossegurança de OGMs & 4 & & \\
\hline Fixação de metas internacionais de emissões de CO2 & 5 & & \\
\hline Adesão ao zonamento agroambiental & 6 & & \\
\hline
\end{tabular}


ETAPA 3 - Questionário de identificação das variáveis-chaves

Prezado(a) Senhor(a),

O propósito dessa etapa de pesquisa é obter informações para identificar as variáveis que mais influenciam o setor produtivo a partir do desenvolvimento do etanol de segunda geração.

As variáveis em análise são um conjunto de tendências e incertezas do setor. Deseja-se qualificá-las nos seguintes aspectos:

a) Grau de influência no desenvolvimento do etanol de segunda geração

b) Grau de dependência entre as variáveis

O processo de avaliação das variáveis nesta fase é comparativo. Cada variável será comparada com as demais para cada um dos procedimentos a seguir:

BLOCO 1 - Qualificação das Variáveis

Neste procedimento, é realizada uma avaliação comparativa entre as variáveis do grau de influência das mesmas no desenvolvimento do etanol de segunda geração. Para a variável que tiver uma influência superior que a variável comparada, então atribui-se (pos), caso contrário atribui-se (neg).

BLOCO 2 - Qualificação de dependência de variáveis.

Aqui, o entrevistado deve analisar se há uma relação de dependência entre as variáveis. Para a variável que tiver uma relação de dependência com a variável em análise, deve ser assinalado (S) em caso positivo e (N) em caso negativo.

BLOCO 3 - Tipo de dependência entre as variáveis - causa e efeito

Essa etapa só é executada caso tenha-se assinalado (S) no procedimento 2. Nesse procedimento deverá ser informado qual tipo de dependência há entre as variáveis. Para a variável que tiver poder de influência sobre a variável em análise, deve-se assinalar (C), indicando relação de causa. Caso contrário, para a variável que for influenciada pela variável em análise, deve-se assinalar (E), relação de efeito.

BLOCO 4 - Grau de dependência das variáveis

Esta etapa, assim como no procedimento 3, só é executada se o procedimento 2 tiver sido positivo (S). Aqui se julgará o grau de dependência entre a variável apresentada e a variável em análise, (1) para baixa dependência, (2) para dependência média e (3) para dependência alta.

Tabelas para coleta de dados da terceira etapa: 


\begin{tabular}{|c|c|c|c|c|c|}
\hline Variável analisada & $\begin{array}{l}\text { Aspectos Econômicos - } 9 \\
\text { Preço do etanol }\end{array}$ & & & & \\
\hline & & Infl. & Dep. & Tipo & Grau \\
\hline Força & Descrição & $\begin{array}{l}\text { Pos. ou } \\
\text { Neg. }\end{array}$ & S ou N & Ca. ou Ef. & $\begin{array}{l}\mathrm{B}, \mathrm{M} \\
\text { ou A }\end{array}$ \\
\hline Aspectos Econômicos - 2 & Preço do petróleo & & & & \\
\hline Universidade - 2 & $\begin{array}{l}\text { Força a formação de recursos } \\
\text { humanos }\end{array}$ & & & & \\
\hline \begin{tabular}{|l|} 
Usinas - 2 \\
\end{tabular} & \begin{tabular}{|l} 
Força a integração da \\
tecnologia de 1 1.a geração com a \\
tecnologia de 2 2.a geração
\end{tabular} & & & & \\
\hline Aspectos Tecnológicos - 3 & $\begin{array}{l}\text { Viabilidade de hidrolizar } \\
\text { resíduos agrícolas }\end{array}$ & & & & \\
\hline Aspectos Tecnológicos - 5 & $\begin{array}{l}\text { Pesquisa brasileira em } \\
\text { biocombustíveis é } \\
\text { internacionalizada e possuidora } \\
\text { de classe mundial }\end{array}$ & & & & \\
\hline Centro Tec.- 2 & $\begin{array}{l}\text { Força o desenvolvimento de } \\
\text { coquetéis enzimáticos mais } \\
\text { eficientes }\end{array}$ & & & & \\
\hline Aspectos Econômicos - 10 & $\begin{array}{l}\text { Alto potencial produtivo de } \\
\text { biomassa no Brasil }\end{array}$ & & & & \\
\hline Aspectos Políticos - 4 & $\begin{array}{l}\text { Aspecto estratégico na } \\
\text { diversificação da matriz } \\
\text { energética }\end{array}$ & & & & \\
\hline Entidade de Classe - 1 & $\begin{array}{l}\text { Força abertura de mercados } \\
\text { nacionais e internacionais para } \\
\text { o etanol brasileiro } \\
\end{array}$ & & & & \\
\hline Usinas - 1 & Força a mecanização agrícola & & & & \\
\hline Aspectos Sociais - 2 & $\begin{array}{l}\text { Término da queima e da } \\
\text { colheita manual da cana }\end{array}$ & & & & \\
\hline Aspectos Políticos - 1 & Comoditização do etanol & & & & \\
\hline $\begin{array}{l}\text { Órgãos de Fomento à } \\
\text { Pesquisa - } 1\end{array}$ & \begin{tabular}{|lrr} 
Financia a pesquisa & nos \\
gargalos técnicos & para \\
consolidação do etanol de & de \\
segunda geração & & \\
\end{tabular} & & & & \\
\hline Aspectos Sociais - 1 & $\begin{array}{l}\text { Adequação do setor às normas } \\
\text { trabalhistas }\end{array}$ & & & & \\
\hline Aspectos Econômicos - 5 & \begin{tabular}{|l|} 
Logística brasileira favorável \\
para uso da biomassa (bagaço)
\end{tabular} & & & & \\
\hline Aspectos Econômicos - 7 & $\begin{array}{l}\text { Tendência de fusões e } \\
\text { aquisições no setor }\end{array}$ & & & & \\
\hline Aspectos Políticos - 2 & \begin{tabular}{|l} 
Criação de subsídios para \\
consolidação do etanol de \\
segunda geração
\end{tabular} & & & & \\
\hline Aspectos Ambientais - 2 & $\begin{array}{l}\text { Agravamento das mudanças } \\
\text { climáticas }\end{array}$ & & & & \\
\hline Usinas - 3 & $\begin{array}{l}\text { Concorrência pelo bagaço entre } \\
\text { etanol de segunda geração e a } \\
\text { bioeletrecidade }\end{array}$ & & & & \\
\hline $\begin{array}{l}\text { Órgãos de Fomento à } \\
\text { Pesquisa - } 2\end{array}$ & $\begin{array}{l}\text { Mudanças } \text { genéticas } \\
\text { fisiológicas na cana para pré- } \\
\text { hidrólisar o bagaço na fase } \\
\text { agrícola }\end{array}$ & & & & \\
\hline
\end{tabular}




\begin{tabular}{|c|c|c|c|c|c|}
\hline Variável analisada & $\begin{array}{l}\text { Aspectos Econômicos - } 2 \\
\text { Preço do petróleo }\end{array}$ & & & & \\
\hline & & Infl. & Dep. & Tipo & Grau \\
\hline Força & Descrição & $\begin{array}{l}\text { Pos. ou } \\
\text { Neg. }\end{array}$ & S ou N & Ca. ou Ef. & $\begin{array}{l}\mathrm{B}, \mathrm{M} \\
\text { ou A }\end{array}$ \\
\hline Universidade - 2 & $\begin{array}{l}\text { Força a formação de recursos } \\
\text { humanos }\end{array}$ & & & & \\
\hline Usinas - 2 & $\begin{array}{l}\text { Força a integração da } \\
\text { tecnologia de 1.a geração com a } \\
\text { tecnologia de }\end{array}$ & & & & \\
\hline Aspectos Tecnológicos - 3 & $\begin{array}{l}\text { Viabilidade de hidrolizar } \\
\text { resíduos agrícolas }\end{array}$ & & & & \\
\hline Aspectos Tecnológicos - 5 & $\begin{array}{l}\text { Pesquisa brasileira em } \\
\text { biocombustíveis é } \\
\text { internacionalizada e possuidora } \\
\text { de classe mundial } \\
\end{array}$ & & & & \\
\hline Centro Tec.- 2 & \begin{tabular}{|lll} 
Força o desenvolvimento de \\
coquetéis enzimáticos mais \\
eficientes
\end{tabular} & & & & \\
\hline Aspectos Econômicos - 10 & $\begin{array}{l}\text { Alto potencial produtivo de } \\
\text { biomassa no Brasil }\end{array}$ & & & & \\
\hline Aspectos Políticos - 4 & $\begin{array}{l}\text { Aspecto estratégico na } \\
\text { diversificação da matriz } \\
\text { energética }\end{array}$ & & & & \\
\hline Entidade de Classe - 1 & $\begin{array}{l}\text { Força abertura de mercados } \\
\text { nacionais e internacionais para } \\
\text { o etanol brasileiro }\end{array}$ & & & & \\
\hline \begin{tabular}{|l|} 
Usinas - 1 \\
\end{tabular} & Força a mecanização agrícola & & & & \\
\hline Aspectos Sociais - 2 & $\begin{array}{l}\text { Término da queima e da } \\
\text { colheita manual da cana }\end{array}$ & & & & \\
\hline Aspectos Políticos - 1 & Comoditização do etanol & & & & \\
\hline $\begin{array}{l}\text { Órgãos de Fomento à } \\
\text { Pesquisa - } 1\end{array}$ & \begin{tabular}{|lrr} 
Financia a pesquisa & nos \\
gargalos técnicos & para \\
consolidação do etanol de & de \\
segunda geração & & \\
\end{tabular} & & & & \\
\hline Aspectos Sociais - 1 & $\begin{array}{l}\text { Adequação do setor às normas } \\
\text { trabalhistas }\end{array}$ & & & & \\
\hline Aspectos Econômicos - 5 & \begin{tabular}{|l|} 
Logística brasileira favorável \\
para uso da biomassa (bagaço)
\end{tabular} & & & & \\
\hline Aspectos Econômicos - 7 & $\begin{array}{l}\text { Tendência de fusões e } \\
\text { aquisições no setor }\end{array}$ & & & & \\
\hline Aspectos Políticos - 2 & \begin{tabular}{|l|} 
Criação de subsídios para \\
consolidação do etanol de \\
segunda geração
\end{tabular} & & & & \\
\hline Aspectos Ambientais - 2 & $\begin{array}{l}\text { Agravamento das mudanças } \\
\text { climáticas }\end{array}$ & & & & \\
\hline Usinas - 3 & $\begin{array}{l}\text { Concorrência pelo bagaço entre } \\
\text { etanol de segunda geração e a } \\
\text { bioeletrecidade }\end{array}$ & & & & \\
\hline $\begin{array}{l}\text { Órgãos de Fomento à } \\
\text { Pesquisa - } 2\end{array}$ & 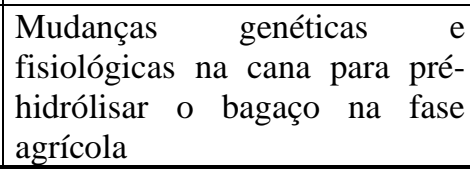 & & & & \\
\hline
\end{tabular}




\begin{tabular}{|c|c|c|c|c|c|}
\hline Variável analisada & $\begin{array}{c}\text { Universidade - } 2 \text { Força a } \\
\text { formação de recursos } \\
\text { humanos }\end{array}$ & & & & \\
\hline & & Infl. & Dep. & Tipo & Grau \\
\hline Força & Descrição & $\begin{array}{l}\text { Pos. ou } \\
\text { Neg. }\end{array}$ & S ou N & Ca. ou Ef. & $\begin{array}{l}\mathrm{B}, \mathrm{M} \\
\text { ou A }\end{array}$ \\
\hline Usinas - 2 & $\begin{array}{l}\text { Força a integração da } \\
\text { tecnologia de 1.a geração com a } \\
\text { tecnologia de } 2 \text {.a geração }\end{array}$ & & & & \\
\hline Aspectos Tecnológicos - 3 & $\begin{array}{l}\text { Viabilidade de hidrolizar } \\
\text { resíduos agrícolas }\end{array}$ & & & & \\
\hline Aspectos Tecnológicos - 5 & $\begin{array}{l}\text { Pesquisa brasileira em } \\
\text { biocombustíveis é } \\
\text { internacionalizada e possuidora } \\
\text { de classe mundial } \\
\end{array}$ & & & & \\
\hline Centro Tec.- 2 & \begin{tabular}{|lrr} 
Força o desenvolvimento de \\
coquetéis & enzimáticos mais \\
eficientes & & \\
\end{tabular} & & & & \\
\hline Aspectos Econômicos - 10 & $\begin{array}{l}\text { Alto potencial produtivo de } \\
\text { biomassa no Brasil }\end{array}$ & & & & \\
\hline Aspectos Políticos - 4 & $\begin{array}{l}\text { Aspecto estratégico na } \\
\text { diversificação da matriz } \\
\text { energética }\end{array}$ & & & & \\
\hline Entidade de Classe - 1 & $\begin{array}{l}\text { Força abertura de mercados } \\
\text { nacionais e internacionais para } \\
\text { o etanol brasileiro }\end{array}$ & & & & \\
\hline Usinas - 1 & Força a mecanização agrícola & & & & \\
\hline Aspectos Sociais - 2 & $\begin{array}{l}\text { Término da queima e da } \\
\text { colheita manual da cana }\end{array}$ & & & & \\
\hline \begin{tabular}{|l|} 
Aspectos Políticos - 1 \\
\end{tabular} & Comoditização do etanol & & & & \\
\hline $\begin{array}{l}\text { Órgãos de Fomento à } \\
\text { Pesquisa - } 1\end{array}$ & $\begin{array}{|lrr|}\text { Financia a pesquisa } & \text { nos } \\
\text { gargalos técnicos para } \\
\text { consolidação do etanol } & \text { de } \\
\text { segunda geração } & & \\
\end{array}$ & & & & \\
\hline Aspectos Sociais - 1 & $\begin{array}{l}\text { Adequação do setor às normas } \\
\text { trabalhistas }\end{array}$ & & & & \\
\hline Aspectos Econômicos - 5 & \begin{tabular}{|l|} 
Logística brasileira favorável \\
para uso da biomassa (bagaço)
\end{tabular} & & & & \\
\hline Aspectos Econômicos - 7 & $\begin{array}{l}\text { Tendência de fusões e } \\
\text { aquisições no setor }\end{array}$ & & & & \\
\hline Aspectos Políticos - 2 & \begin{tabular}{|l|} 
Criação de subsídios para \\
consolidação do etanol de \\
segunda geração
\end{tabular} & & & & \\
\hline Aspectos Ambientais - 2 & $\begin{array}{l}\text { Agravamento das mudanças } \\
\text { climáticas }\end{array}$ & & & & \\
\hline Usinas - 3 & $\begin{array}{l}\text { Concorrência pelo bagaço entre } \\
\text { etanol de segunda geração e a } \\
\text { bioeletrecidade }\end{array}$ & & & & \\
\hline $\begin{array}{l}\text { Órgãos de Fomento à } \\
\text { Pesquisa - } 2\end{array}$ & 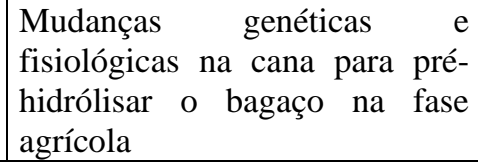 & & & & \\
\hline
\end{tabular}




\begin{tabular}{|c|c|c|c|c|c|}
\hline Variável analisada & $\begin{array}{c}\text { Usinas - } 2 \text { Força a integração } \\
\text { da tecnologia de 1.a geração } \\
\text { com a tecnologia de 2.a } \\
\text { geração }\end{array}$ & & & & \\
\hline & & Infl. & Dep. & Tipo & Grau \\
\hline Força & Descrição & $\begin{array}{l}\text { Pos. ou } \\
\text { Neg. }\end{array}$ & S ou N & Ca. ou Ef. & $\begin{array}{l}B, M \\
\text { ou } A\end{array}$ \\
\hline Aspectos Tecnológicos - 3 & $\begin{array}{l}\text { Viabilidade de hidrolizar } \\
\text { resíduos agrícolas }\end{array}$ & & & & \\
\hline Aspectos Tecnológicos - 5 & $\begin{array}{l}\text { Pesquisa brasileira em } \\
\text { biocombustíveis é } \\
\text { internacionalizada e possuidora } \\
\text { de classe mundial }\end{array}$ & & & & \\
\hline Centro Tec.- 2 & $\begin{array}{l}\begin{array}{l}\text { Força o } \\
\text { coquetéis } \\
\text { conzicientes }\end{array} \\
\text { efimáticos }\end{array}$ & & & & \\
\hline Aspectos Econômicos - 10 & $\begin{array}{l}\text { Alto potencial produtivo de } \\
\text { biomassa no Brasil }\end{array}$ & & & & \\
\hline Aspectos Políticos - 4 & $\begin{array}{l}\text { Aspecto estratégico na } \\
\text { diversificação da matriz } \\
\text { energética }\end{array}$ & & & & \\
\hline Entidade de Classe - 1 & $\begin{array}{l}\text { Força abertura de mercados } \\
\text { nacionais e internacionais para } \\
\text { o etanol brasileiro }\end{array}$ & & & & \\
\hline Usinas - 1 & Força a mecanização agrícola & & & & \\
\hline Aspectos Sociais - 2 & $\begin{array}{l}\text { Término da queima e da } \\
\text { colheita manual da cana }\end{array}$ & & & & \\
\hline Aspectos Políticos - 1 & Comoditização do etanol & & & & \\
\hline $\begin{array}{l}\text { Órgãos de Fomento à } \\
\text { Pesquisa - } 1\end{array}$ & $\begin{array}{llrr}\text { Financia a pesquisa } & \text { nos } \\
\text { gargalos } & \text { técnicos } & \text { para } \\
\text { consolidação do etanol } & \text { de } \\
\text { segunda geração } & & \\
\end{array}$ & & & & \\
\hline Aspectos Sociais - 1 & $\begin{array}{l}\text { Adequação do setor às normas } \\
\text { trabalhistas }\end{array}$ & & & & \\
\hline Aspectos Econômicos - 5 & $\begin{array}{l}\text { Logística brasileira favorável } \\
\text { para uso da biomassa (bagaço) }\end{array}$ & & & & \\
\hline Aspectos Econômicos - 7 & $\begin{array}{l}\text { Tendência de fusões e } \\
\text { aquisições no setor }\end{array}$ & & & & \\
\hline Aspectos Políticos - 2 & $\begin{array}{l}\text { Criação de subsídios para } \\
\text { consolidação do etanol de } \\
\text { segunda geração }\end{array}$ & & & & \\
\hline Aspectos Ambientais - 2 & $\begin{array}{l}\text { Agravamento das mudanças } \\
\text { climáticas }\end{array}$ & & & & \\
\hline Usinas - 3 & $\begin{array}{l}\text { Concorrência pelo bagaço entre } \\
\text { etanol de segunda geração e a } \\
\text { bioeletrecidade }\end{array}$ & & & & \\
\hline $\begin{array}{l}\text { Órgãos de Fomento à } \\
\text { Pesquisa - } 2\end{array}$ & $\begin{array}{l}\text { Mudanças } \text { genéticas } \\
\text { fisiológicas na cana para pré- } \\
\text { hidrólisar o bagaço na fase } \\
\text { agrícola }\end{array}$ & & & & \\
\hline
\end{tabular}




\begin{tabular}{|c|c|c|c|c|c|}
\hline Variável analisada & $\begin{array}{l}\text { Aspectos Tecnológicos - } 3 \\
\text { Viabilidade de hidrolizar } \\
\text { resíduos agrícolas }\end{array}$ & & & & \\
\hline & & Infl. & Dep. & Tipo & Grau \\
\hline Força & Descrição & $\begin{array}{l}\text { Pos. ou } \\
\text { Neg. }\end{array}$ & S ou N & Ca. ou Ef. & $\begin{array}{l}\text { B, M } \\
\text { ou A }\end{array}$ \\
\hline Aspectos Tecnológicos - 5 & $\begin{array}{l}\text { Pesquisa brasileira em } \\
\text { biocombustíveis é } \\
\text { internacionalizada e possuidora } \\
\text { de classe mundial }\end{array}$ & & & & \\
\hline Centro Tec.- 2 & 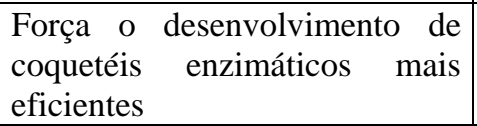 & & & & \\
\hline Aspectos Econômicos - 10 & $\begin{array}{l}\text { Alto potencial produtivo de } \\
\text { biomassa no Brasil }\end{array}$ & & & & \\
\hline Aspectos Políticos - 4 & $\begin{array}{l}\text { Aspecto estratégico na } \\
\text { diversificação da matriz } \\
\text { energética }\end{array}$ & & & & \\
\hline Entidade de Classe - 1 & $\begin{array}{l}\text { Força abertura de mercados } \\
\text { nacionais e internacionais para } \\
\text { o etanol brasileiro }\end{array}$ & & & & \\
\hline Usinas - 1 & Força a mecanização agrícola & & & & \\
\hline Aspectos Sociais - 2 & $\begin{array}{l}\text { Término da queima e da } \\
\text { colheita manual da cana }\end{array}$ & & & & \\
\hline Aspectos Políticos - 1 & Comoditização do etanol & & & & \\
\hline $\begin{array}{l}\text { Órgãos de Fomento à } \\
\text { Pesquisa - } 1\end{array}$ & $\begin{array}{lrrr}\text { Financia a pesquisa } & \text { nos } \\
\text { gargalos técnicos } & \text { para } \\
\text { consolidação do etanol } & \text { de } \\
\text { segunda geração } & & \end{array}$ & & & & \\
\hline Aspectos Sociais - 1 & $\begin{array}{l}\text { Adequação do setor às normas } \\
\text { trabalhistas }\end{array}$ & & & & \\
\hline Aspectos Econômicos - 5 & $\begin{array}{l}\text { Logística brasileira favorável } \\
\text { para uso da biomassa (bagaço) }\end{array}$ & & & & \\
\hline Aspectos Econômicos - 7 & $\begin{array}{l}\text { Tendência de fusões e } \\
\text { aquisições no setor }\end{array}$ & & & & \\
\hline Aspectos Políticos - 2 & $\begin{array}{l}\text { Criação de subsídios para } \\
\text { consolidação do etanol de } \\
\text { segunda geração }\end{array}$ & & & & \\
\hline Aspectos Ambientais - 2 & $\begin{array}{l}\text { Agravamento das mudanças } \\
\text { climáticas }\end{array}$ & & & & \\
\hline Usinas - 3 & $\begin{array}{l}\text { Concorrência pelo bagaço entre } \\
\text { etanol de segunda geração e a } \\
\text { bioeletrecidade }\end{array}$ & & & & \\
\hline $\begin{array}{l}\text { Órgãos de Fomento à } \\
\text { Pesquisa - } 2\end{array}$ & $\begin{array}{l}\text { Mudanças } \quad \text { genéticas } \\
\text { fisiológicas na cana para pré- } \\
\text { hidrólisar o bagaço na fase } \\
\text { agrícola }\end{array}$ & & & & \\
\hline
\end{tabular}




\begin{tabular}{|c|c|c|c|c|c|}
\hline Variável analisada & $\begin{array}{c}\text { Aspectos Tecnológicos - } 5 \\
\text { Pesquisa brasileira em } \\
\text { biocombustíveis é } \\
\text { internacionalizada e } \\
\text { possuidora de classe mundial }\end{array}$ & & & & \\
\hline & & Infl. & Dep. & Tipo & Grau \\
\hline Força & Descrição & $\begin{array}{l}\text { Pos. ou } \\
\text { Neg. }\end{array}$ & $\mathrm{S}$ ou $\mathrm{N}$ & Ca. ou Ef. & $\begin{array}{l}\mathrm{B}, \mathrm{M} \\
\text { ou A }\end{array}$ \\
\hline Centro Tec.- 2 & $\begin{array}{l}\text { Força o desenvolvimento de } \\
\text { coquetéis enzimáticos mais } \\
\text { eficientes }\end{array}$ & & & & \\
\hline Aspectos Econômicos - 10 & $\begin{array}{l}\text { Alto potencial produtivo de } \\
\text { biomassa no Brasil }\end{array}$ & & & & \\
\hline Aspectos Políticos - 4 & $\begin{array}{l}\text { Aspecto estratégico na } \\
\text { diversificação da matriz } \\
\text { energética }\end{array}$ & & & & \\
\hline Entidade de Classe - 1 & $\begin{array}{l}\text { Força abertura de mercados } \\
\text { nacionais e internacionais para } \\
\text { o etanol brasileiro }\end{array}$ & & & & \\
\hline Usinas - 1 & Força a mecanização agrícola & & & & \\
\hline Aspectos Sociais - 2 & $\begin{array}{l}\text { Término da queima e da } \\
\text { colheita manual da cana }\end{array}$ & & & & \\
\hline Aspectos Políticos - 1 & Comoditização do etanol & & & & \\
\hline $\begin{array}{l}\text { Órgãos de Fomento à } \\
\text { Pesquisa - } 1\end{array}$ & $\begin{array}{llr}\text { Financia a pesquisa } & \text { nos } \\
\text { gargalos técnicos } & \text { para } \\
\text { consolidação do etanol } & \text { de } \\
\text { segunda geração } & & \\
\end{array}$ & & & & \\
\hline Aspectos Sociais - 1 & $\begin{array}{l}\text { Adequação do setor às normas } \\
\text { trabalhistas }\end{array}$ & & & & \\
\hline Aspectos Econômicos - 5 & $\begin{array}{l}\text { Logística brasileira favorável } \\
\text { para uso da biomassa (bagaço) }\end{array}$ & & & & \\
\hline Aspectos Econômicos - 7 & $\begin{array}{l}\text { Tendência de fusões e } \\
\text { aquisições no setor }\end{array}$ & & & & \\
\hline Aspectos Políticos - 2 & $\begin{array}{l}\text { Criação de subsídios para } \\
\text { consolidação do etanol de } \\
\text { segunda geração }\end{array}$ & & & & \\
\hline Aspectos Ambientais - 2 & $\begin{array}{l}\text { Agravamento das mudanças } \\
\text { climáticas }\end{array}$ & & & & \\
\hline Usinas - 3 & $\begin{array}{l}\text { Concorrência pelo bagaço entre } \\
\text { etanol de segunda geração e a } \\
\text { bioeletrecidade }\end{array}$ & & & & \\
\hline $\begin{array}{l}\text { Órgãos de Fomento à } \\
\text { Pesquisa - } 2\end{array}$ & $\begin{array}{l}\text { Mudanças genéticas } \\
\text { fisiológicas na cana para pré- } \\
\text { hidrólisar o bagaço na fase } \\
\text { agrícola }\end{array}$ & & & & \\
\hline
\end{tabular}




\begin{tabular}{|c|c|c|c|c|c|}
\hline Variável analisada & $\begin{array}{c}\text { Centro Tec.- } 2 \text { Força o } \\
\text { desenvolvimento de coquetéis } \\
\text { enzimáticos mais eficientes }\end{array}$ & & & & \\
\hline & & Infl. & Dep. & Tipo & Grau \\
\hline Força & Descrição & $\begin{array}{l}\text { Pos. ou } \\
\text { Neg. }\end{array}$ & $\mathrm{S}$ ou $\mathrm{N}$ & Ca. ou Ef. & $\begin{array}{l}\mathrm{B}, \mathrm{M} \\
\text { ou A }\end{array}$ \\
\hline Aspectos Econômicos - 10 & $\begin{array}{l}\text { Alto potencial produtivo de } \\
\text { biomassa no Brasil }\end{array}$ & & & & \\
\hline Aspectos Políticos - 4 & $\begin{array}{l}\text { Aspecto estratégico na } \\
\text { diversificação da matriz } \\
\text { energética }\end{array}$ & & & & \\
\hline Entidade de Classe - 1 & $\begin{array}{l}\text { Força abertura de mercados } \\
\text { nacionais e internacionais para } \\
\text { o etanol brasileiro }\end{array}$ & & & & \\
\hline Usinas - 1 & Força a mecanização agrícola & & & & \\
\hline Aspectos Sociais - 2 & $\begin{array}{l}\text { Término da queima e da } \\
\text { colheita manual da cana }\end{array}$ & & & & \\
\hline Aspectos Políticos - 1 & Comoditização do etanol & & & & \\
\hline $\begin{array}{l}\text { Órgãos de Fomento à } \\
\text { Pesquisa - } 1\end{array}$ & $\begin{array}{llr}\text { Financia a pesquisa } & \text { nos } \\
\text { gargalos } & \text { técnicos } & \text { para } \\
\text { consolidação do etanol } & \text { de } \\
\text { segunda geração } & & \\
\end{array}$ & & & & \\
\hline Aspectos Sociais - 1 & $\begin{array}{l}\text { Adequação do setor às normas } \\
\text { trabalhistas }\end{array}$ & & & & \\
\hline Aspectos Econômicos - 5 & $\begin{array}{l}\text { Logística brasileira favorável } \\
\text { para uso da biomassa (bagaço) }\end{array}$ & & & & \\
\hline Aspectos Econômicos - 7 & $\begin{array}{l}\text { Tendência de fusões e } \\
\text { aquisições no setor }\end{array}$ & & & & \\
\hline Aspectos Políticos - 2 & $\begin{array}{l}\text { Criação de subsídios para } \\
\text { consolidação do etanol de } \\
\text { segunda geração }\end{array}$ & & & & \\
\hline Aspectos Ambientais - 2 & $\begin{array}{l}\text { Agravamento das mudanças } \\
\text { climáticas }\end{array}$ & & & & \\
\hline Usinas - 3 & $\begin{array}{l}\text { Concorrência pelo bagaço entre } \\
\text { etanol de segunda geração e a } \\
\text { bioeletrecidade }\end{array}$ & & & & \\
\hline $\begin{array}{l}\text { Órgãos de Fomento à } \\
\text { Pesquisa - } 2\end{array}$ & $\begin{array}{l}\text { Mudanças genéticas } \\
\text { fisiológicas na cana para pré- } \\
\text { hidrólisar o bagaço na fase } \\
\text { agrícola }\end{array}$ & & & & \\
\hline
\end{tabular}




\begin{tabular}{|c|c|c|c|c|c|}
\hline Variável analisada & $\begin{array}{l}\text { Aspectos Econômicos - 10 } \\
\text { Alto potencial produtivo de } \\
\text { biomassa no Brasil } \\
\end{array}$ & & & & \\
\hline & & Infl. & Dep. & Tipo & Grau \\
\hline Força & Descrição & $\begin{array}{l}\text { Pos. ou } \\
\text { Neg. }\end{array}$ & S ou N & Ca. ou Ef. & $\begin{array}{l}\mathrm{B}, \mathrm{M} \\
\text { ou A }\end{array}$ \\
\hline Aspectos Políticos - 4 & $\begin{array}{l}\text { Aspecto estratégico na } \\
\text { diversificação da matriz } \\
\text { energética }\end{array}$ & & & & \\
\hline Entidade de Classe - 1 & $\begin{array}{l}\text { Força abertura de mercados } \\
\text { nacionais e internacionais para } \\
\text { o etanol brasileiro }\end{array}$ & & & & \\
\hline Usinas - 1 & Força a mecanização agrícola & & & & \\
\hline Aspectos Sociais - 2 & $\begin{array}{l}\text { Término da queima e da } \\
\text { colheita manual da cana }\end{array}$ & & & & \\
\hline Aspectos Políticos - 1 & Comoditização do etanol & & & & \\
\hline $\begin{array}{l}\text { Órgãos de Fomento à } \\
\text { Pesquisa - } 1\end{array}$ & $\begin{array}{|lrr|}\text { Financia a pesquisa } & \text { nos } \\
\text { gargalos } & \text { técnicos } & \text { para } \\
\text { consolidação do etanol } & \text { de } \\
\text { segunda geração } & & \\
\end{array}$ & & & & \\
\hline Aspectos Sociais - 1 & $\begin{array}{l}\begin{array}{l}\text { Adequação do setor às normas } \\
\text { trabalhistas }\end{array} \\
\end{array}$ & & & & \\
\hline Aspectos Econômicos - 5 & \begin{tabular}{|l|l} 
Logística brasileira favorável \\
para uso da biomassa (bagaço)
\end{tabular} & & & & \\
\hline Aspectos Econômicos - 7 & $\begin{array}{l}\text { Tendência de fusões e } \\
\text { aquisições no setor }\end{array}$ & & & & \\
\hline Aspectos Políticos - 2 & $\begin{array}{l}\text { Criação de subsídios para } \\
\text { consolidação do etanol de } \\
\text { segunda geração }\end{array}$ & & & & \\
\hline Aspectos Ambientais - 2 & $\begin{array}{l}\text { Agravamento das mudanças } \\
\text { climáticas }\end{array}$ & & & & \\
\hline Usinas - 3 & $\begin{array}{l}\text { Concorrência pelo bagaço entre } \\
\text { etanol de segunda geração e a } \\
\text { bioeletrecidade }\end{array}$ & & & & \\
\hline $\begin{array}{l}\text { Órgãos de Fomento à } \\
\text { Pesquisa - } 2\end{array}$ & $\begin{array}{l}\text { Mudanças } \quad \text { genéticas } \\
\text { fisiológicas na cana para pré- } \\
\text { hidrólisar o bagaço na } \\
\text { agrícola }\end{array}$ & & & & \\
\hline
\end{tabular}




\begin{tabular}{|c|c|c|c|c|c|}
\hline Variável analisada & $\begin{array}{c}\text { Aspectos Políticos - } 4 \text { Aspecto } \\
\text { estratégico na diversificação } \\
\text { da matriz energética }\end{array}$ & & & & \\
\hline & & Infl. & Dep. & Tipo & Grau \\
\hline Força & Descrição & $\begin{array}{l}\text { Pos. ou } \\
\text { Neg. }\end{array}$ & S ou $\mathrm{N}$ & Ca. ou Ef. & $\begin{array}{l}\mathrm{B}, \mathrm{M} \\
\text { ou A }\end{array}$ \\
\hline Entidade de Classe - 1 & $\begin{array}{l}\text { Força abertura de mercados } \\
\text { nacionais e internacionais para } \\
\text { o etanol brasileiro }\end{array}$ & & & & \\
\hline Usinas - 1 & Força a mecanização agrícola & & & & \\
\hline Aspectos Sociais - 2 & $\begin{array}{l}\text { Término da queima e da } \\
\text { colheita manual da cana }\end{array}$ & & & & \\
\hline Aspectos Políticos - 1 & Comoditização do etanol & & & & \\
\hline $\begin{array}{l}\text { Órgãos de Fomento à } \\
\text { Pesquisa - } 1\end{array}$ & $\begin{array}{llr}\text { Financia a pesquisa } & \text { nos } \\
\text { gargalos técnicos } & \text { para } \\
\text { consolidação do etanol } & \text { de } \\
\text { segunda geração } & & \\
\end{array}$ & & & & \\
\hline Aspectos Sociais - 1 & $\begin{array}{l}\text { Adequação do setor às normas } \\
\text { trabalhistas }\end{array}$ & & & & \\
\hline Aspectos Econômicos - 5 & $\begin{array}{l}\text { Logística brasileira favorável } \\
\text { para uso da biomassa (bagaço) }\end{array}$ & & & & \\
\hline Aspectos Econômicos - 7 & $\begin{array}{l}\text { Tendência de fusões e } \\
\text { aquisições no setor }\end{array}$ & & & & \\
\hline Aspectos Políticos - 2 & $\begin{array}{l}\text { Criação de subsídios para } \\
\text { consolidação do etanol de } \\
\text { segunda geração }\end{array}$ & & & & \\
\hline Aspectos Ambientais - 2 & $\begin{array}{l}\text { Agravamento das mudanças } \\
\text { climáticas }\end{array}$ & & & & \\
\hline Usinas - 3 & $\begin{array}{l}\text { Concorrência pelo bagaço entre } \\
\text { etanol de segunda geração e a } \\
\text { bioeletrecidade }\end{array}$ & & & & \\
\hline $\begin{array}{l}\text { Órgãos de Fomento à } \\
\text { Pesquisa - } 2\end{array}$ & $\begin{array}{l}\text { Mudanças genéticas } \\
\text { fisiológicas na cana para pré- } \\
\text { hidrólisar o bagaço na fase } \\
\text { agrícola }\end{array}$ & & & & \\
\hline
\end{tabular}




\begin{tabular}{|c|c|c|c|c|c|}
\hline Variável analisada & $\begin{array}{c}\text { Entidade de Classe - } 1 \text { Força } \\
\text { abertura de mercados } \\
\text { nacionais e internacionais } \\
\text { para o etanol brasileiro }\end{array}$ & & & & \\
\hline & & Infl. & Dep. & Tipo & Grau \\
\hline Força & Descrição & $\begin{array}{l}\text { Pos. ou } \\
\text { Neg. }\end{array}$ & S ou $\mathrm{N}$ & Ca. ou Ef. & $\begin{array}{l}\mathrm{B}, \mathrm{M} \\
\text { ou A }\end{array}$ \\
\hline Usinas - 1 & Força a mecanização agrícola & & & & \\
\hline Aspectos Sociais - 2 & $\begin{array}{l}\text { Término da queima e da } \\
\text { colheita manual da cana }\end{array}$ & & & & \\
\hline Aspectos Políticos - 1 & Comoditização do etanol & & & & \\
\hline $\begin{array}{l}\text { Órgãos de Fomento à } \\
\text { Pesquisa - } 1\end{array}$ & $\begin{array}{llr}\text { Financia a pesquisa } & \text { nos } \\
\text { gargalos técnicos } & \text { para } \\
\text { consolidação do etanol } & \text { de } \\
\text { segunda geração } & & \end{array}$ & & & & \\
\hline Aspectos Sociais - 1 & $\begin{array}{l}\text { Adequação do setor às normas } \\
\text { trabalhistas }\end{array}$ & & & & \\
\hline Aspectos Econômicos - 5 & $\begin{array}{l}\text { Logística brasileira favorável } \\
\text { para uso da biomassa (bagaço) }\end{array}$ & & & & \\
\hline Aspectos Econômicos - 7 & $\begin{array}{l}\text { Tendência de fusões e } \\
\text { aquisições no setor }\end{array}$ & & & & \\
\hline Aspectos Políticos - 2 & $\begin{array}{l}\text { Criação de subsídios para } \\
\text { consolidação do etanol de } \\
\text { segunda geração }\end{array}$ & & & & \\
\hline Aspectos Ambientais - 2 & $\begin{array}{l}\text { Agravamento das mudanças } \\
\text { climáticas }\end{array}$ & & & & \\
\hline Usinas - 3 & $\begin{array}{l}\text { Concorrência pelo bagaço entre } \\
\text { etanol de segunda geração e a } \\
\text { bioeletrecidade }\end{array}$ & & & & \\
\hline $\begin{array}{l}\text { Órgãos de Fomento à } \\
\text { Pesquisa - } 2\end{array}$ & $\begin{array}{l}\text { Mudanças } \quad \text { genéticas } \\
\text { fisiológicas na cana para pré- } \\
\text { hidrólisar o bagaço na fase } \\
\text { agrícola }\end{array}$ & & & & \\
\hline
\end{tabular}




\begin{tabular}{|c|c|c|c|c|c|}
\hline Variável analisada & $\begin{array}{c}\text { Usinas - } 1 \text { Força a } \\
\text { mecanização agrícola }\end{array}$ & & & & \\
\hline & & Infl. & Dep. & Tipo & Grau \\
\hline Força & Descrição & $\begin{array}{l}\text { Pos. ou } \\
\text { Neg. }\end{array}$ & $\mathrm{S}$ ou $\mathrm{N}$ & Ca. ou Ef. & $\begin{array}{l}\mathrm{B}, \mathrm{M} \\
\text { ou } \mathrm{A}\end{array}$ \\
\hline Aspectos Sociais - 2 & $\begin{array}{l}\text { Término da queima e da } \\
\text { colheita manual da cana }\end{array}$ & & & & \\
\hline Aspectos Políticos - 1 & Comoditização do etanol & & & & \\
\hline $\begin{array}{l}\text { Órgãos de Fomento à } \\
\text { Pesquisa - } 1\end{array}$ & $\begin{array}{llr}\text { Financia a pesquisa } & \text { nos } \\
\text { gargalos técnicos } & \text { para } \\
\text { consolidação do etanol } & \text { de } \\
\text { segunda geração } & & \\
\end{array}$ & & & & \\
\hline Aspectos Sociais - 1 & $\begin{array}{l}\text { Adequação do setor às normas } \\
\text { trabalhistas }\end{array}$ & & & & \\
\hline Aspectos Econômicos - 5 & $\begin{array}{l}\text { Logística brasileira favorável } \\
\text { para uso da biomassa (bagaço) }\end{array}$ & & & & \\
\hline Aspectos Econômicos - 7 & $\begin{array}{l}\text { Tendência de fusões e } \\
\text { aquisições no setor }\end{array}$ & & & & \\
\hline Aspectos Políticos - 2 & $\begin{array}{l}\text { Criação de subsídios para } \\
\text { consolidação do etanol de } \\
\text { segunda geração }\end{array}$ & & & & \\
\hline Aspectos Ambientais - 2 & $\begin{array}{l}\text { Agravamento das mudanças } \\
\text { climáticas }\end{array}$ & & & & \\
\hline Usinas - 3 & $\begin{array}{l}\text { Concorrência pelo bagaço entre } \\
\text { etanol de segunda geração e a } \\
\text { bioeletrecidade }\end{array}$ & & & & \\
\hline $\begin{array}{l}\text { Órgãos de Fomento à } \\
\text { Pesquisa - } 2\end{array}$ & \begin{tabular}{llr} 
Mudanças & \multicolumn{2}{c}{ genéticas } \\
fisiológicas na cana para pré- \\
hidrólisar o bagaço na fase \\
agrícola
\end{tabular} & & & & \\
\hline
\end{tabular}




\begin{tabular}{|c|c|c|c|c|c|}
\hline Variável analisada & $\begin{array}{c}\text { Aspectos Sociais - } 2 \text { Término } \\
\text { da queima e da colheita } \\
\text { manual da cana }\end{array}$ & & & & \\
\hline & & Infl. & Dep. & Tipo & Grau \\
\hline Força & Descrição & $\begin{array}{l}\text { Pos. ou } \\
\text { Neg. }\end{array}$ & S ou N & Ca. ou Ef. & $\begin{array}{l}\text { B, M } \\
\text { ou A }\end{array}$ \\
\hline Aspectos Políticos - 1 & Comoditização do etanol & & & & \\
\hline $\begin{array}{l}\text { Órgãos de Fomento à } \\
\text { Pesquisa - } 1\end{array}$ & \begin{tabular}{|lrr} 
Financia a pesquisa & nos \\
gargalos técnicos & para \\
consolidação do etanol de \\
segunda geração
\end{tabular} & & & & \\
\hline Aspectos Sociais - 1 & $\begin{array}{l}\text { Adequação do setor às normas } \\
\text { trabalhistas }\end{array}$ & & & & \\
\hline Aspectos Econômicos - 5 & \begin{tabular}{|l} 
Logística brasileira favorável \\
para uso da biomassa (bagaço)
\end{tabular} & & & & \\
\hline Aspectos Econômicos - 7 & $\begin{array}{l}\text { Tendência de fusões e } \\
\text { aquisições no setor }\end{array}$ & & & & \\
\hline Aspectos Políticos - 2 & $\begin{array}{l}\text { Criação de subsídios para } \\
\text { consolidação do etanol de } \\
\text { segunda geração }\end{array}$ & & & & \\
\hline Aspectos Ambientais - 2 & $\begin{array}{l}\text { Agravamento das mudanças } \\
\text { climáticas }\end{array}$ & & & & \\
\hline Usinas - 3 & $\begin{array}{l}\text { Concorrência pelo bagaço entre } \\
\text { etanol de segunda geração e a } \\
\text { bioeletrecidade }\end{array}$ & & & & \\
\hline $\begin{array}{l}\text { Órgãos de Fomento à } \\
\text { Pesquisa - } 2\end{array}$ & \begin{tabular}{|l} 
Mudanças \\
fisiológicas na canáticas para pré- \\
hidrólisar o bagaço na fase \\
agrícola
\end{tabular} & & & & \\
\hline
\end{tabular}

\begin{tabular}{|c|c|c|c|c|c|}
\hline Variável analisada & $\begin{array}{c}\text { Aspectos Políticos - } 1 \\
\text { Comoditização do etanol }\end{array}$ & & & & \\
\hline & & Infl. & Dep. & Tіро & Grau \\
\hline Força & Descrição & $\begin{array}{l}\text { Pos. ou } \\
\text { Neg. }\end{array}$ & S ou N & Ca. ou Ef. & $\begin{array}{l}\text { B, M } \\
\text { ou A }\end{array}$ \\
\hline $\begin{array}{l}\text { Órgãos de Fomento à } \\
\text { Pesquisa - } 1\end{array}$ & \begin{tabular}{|lrr} 
Financia a pesquisa & nos \\
gargalos técnicos & para \\
consolidação do etanol de \\
segunda geração
\end{tabular} & & & & \\
\hline Aspectos Sociais - 1 & $\begin{array}{l}\begin{array}{l}\text { Adequação do setor às normas } \\
\text { trabalhistas }\end{array} \\
\end{array}$ & & & & \\
\hline Aspectos Econômicos - 5 & $\begin{array}{l}\text { Logística brasileira favorável } \\
\text { para uso da biomassa (bagaço) }\end{array}$ & & & & \\
\hline Aspectos Econômicos - 7 & $\begin{array}{l}\text { Tendência de fusões e } \\
\text { aquisições no setor }\end{array}$ & & & & \\
\hline Aspectos Políticos - 2 & $\begin{array}{l}\text { Criação de subsídios para } \\
\text { consolidação do etanol de } \\
\text { segunda geração }\end{array}$ & & & & \\
\hline Aspectos Ambientais - 2 & $\begin{array}{l}\text { Agravamento das mudanças } \\
\text { climáticas }\end{array}$ & & & & \\
\hline Usinas - 3 & $\begin{array}{l}\text { Concorrência pelo bagaço entre } \\
\text { etanol de segunda geração e a } \\
\text { bioeletrecidade }\end{array}$ & & & & \\
\hline $\begin{array}{l}\text { Órgãos de Fomento à } \\
\text { Pesquisa - } 2\end{array}$ & $\begin{array}{l}\text { Mudanças } \quad \text { genéticas } \\
\text { fisiológicas na cana para pré- } \\
\text { hidrólisar o bagaço na fase } \\
\text { agrícola }\end{array}$ & & & & \\
\hline
\end{tabular}




\begin{tabular}{|c|c|c|c|c|c|}
\hline Variável analisada & $\begin{array}{c}\text { Órgãos de Fomento à } \\
\text { Pesquisa - } 1 \text { Financia a } \\
\text { pesquisa nos gargalos técnicos } \\
\text { para consolidação do etanol } \\
\text { de segunda geração }\end{array}$ & & & & \\
\hline & & Infl. & Dep. & Tipo & Grau \\
\hline Força & Descrição & $\begin{array}{l}\text { Pos. ou } \\
\text { Neg. }\end{array}$ & $\mathrm{S}$ ou $\mathrm{N}$ & Ca. ou Ef. & $\begin{array}{l}\mathrm{B}, \mathrm{M} \\
\text { ou A }\end{array}$ \\
\hline Aspectos Sociais - 1 & $\begin{array}{l}\text { Adequação do setor às normas } \\
\text { trabalhistas }\end{array}$ & & & & \\
\hline Aspectos Econômicos - 5 & $\begin{array}{l}\text { Logística brasileira favorável } \\
\text { para uso da biomassa (bagaço) }\end{array}$ & & & & \\
\hline Aspectos Econômicos - 7 & $\begin{array}{l}\text { Tendência de fusões e } \\
\text { aquisições no setor }\end{array}$ & & & & \\
\hline Aspectos Políticos - 2 & $\begin{array}{l}\text { Criação de subsídios para } \\
\text { consolidação do etanol de } \\
\text { segunda geração }\end{array}$ & & & & \\
\hline Aspectos Ambientais - 2 & $\begin{array}{l}\text { Agravamento das mudanças } \\
\text { climáticas }\end{array}$ & & & & \\
\hline Usinas - 3 & $\begin{array}{l}\text { Concorrência pelo bagaço entre } \\
\text { etanol de segunda geração e a } \\
\text { bioeletrecidade }\end{array}$ & & & & \\
\hline $\begin{array}{l}\text { Órgãos de Fomento à } \\
\text { Pesquisa - } 2\end{array}$ & $\begin{array}{l}\text { Mudanças genéticas } \\
\text { fisiológicas na cana para pré- } \\
\text { hidrólisar o bagaço na fase } \\
\text { agrícola }\end{array}$ & & & & \\
\hline
\end{tabular}

\begin{tabular}{|c|c|c|c|c|c|}
\hline \multirow[t]{2}{*}{ Variável analisada } & \multirow[t]{2}{*}{$\begin{array}{l}\text { Aspectos Sociais - } 1 \\
\text { Adequação do setor às } \\
\text { normas trabalhistas }\end{array}$} & & & & \\
\hline & & Infl. & Dep. & Tipo & Grau \\
\hline Força & Descrição & $\begin{array}{l}\text { Pos. ou } \\
\text { Neg. }\end{array}$ & S ou $\mathrm{N}$ & Ca. ou Ef. & $\begin{array}{l}\text { B, M } \\
\text { ou A }\end{array}$ \\
\hline Aspectos Econômicos - 5 & $\begin{array}{l}\text { Logística brasileira favorável } \\
\text { para uso da biomassa (bagaço) }\end{array}$ & & & & \\
\hline Aspectos Econômicos - 7 & $\begin{array}{l}\text { Tendência de fusões e } \\
\text { aquisições no setor }\end{array}$ & & & & \\
\hline Aspectos Políticos - 2 & $\begin{array}{l}\text { Criação de subsídios para } \\
\text { consolidação do etanol de } \\
\text { segunda geração }\end{array}$ & & & & \\
\hline Aspectos Ambientais - 2 & $\begin{array}{l}\text { Agravamento das mudanças } \\
\text { climáticas }\end{array}$ & & & & \\
\hline Usinas - 3 & $\begin{array}{l}\text { Concorrência pelo bagaço entre } \\
\text { etanol de segunda geração e a } \\
\text { bioeletrecidade }\end{array}$ & & & & \\
\hline $\begin{array}{l}\text { Órgãos de Fomento à } \\
\text { Pesquisa - } 2\end{array}$ & $\begin{array}{l}\text { Mudanças } \frac{\text { genéticas }}{\mathrm{e}} \\
\text { fisiológicas na cana para pré- } \\
\text { hidrólisar o bagaço na fase } \\
\text { agrícola }\end{array}$ & & & & \\
\hline
\end{tabular}




\begin{tabular}{|c|c|c|c|c|c|}
\hline Variável analisada & $\begin{array}{c}\text { Aspectos Econômicos - } 5 \\
\text { Logística brasileira favorável } \\
\text { para uso da biomassa } \\
\text { (bagaço) } \\
\end{array}$ & & & & \\
\hline & & Infl. & Dep. & Tipo & Grau \\
\hline Força & Descrição & $\begin{array}{l}\text { Pos. ou } \\
\text { Neg. }\end{array}$ & S ou $\mathrm{N}$ & Ca. ou Ef. & $\begin{array}{l}\mathrm{B}, \mathrm{M} \\
\text { ou A }\end{array}$ \\
\hline Aspectos Econômicos - 7 & $\begin{array}{l}\text { Tendência de fusões e } \\
\text { aquisições no setor }\end{array}$ & & & & \\
\hline Aspectos Políticos - 2 & $\begin{array}{l}\text { Criação de subsídios para } \\
\text { consolidação do etanol de } \\
\text { segunda geração }\end{array}$ & & & & \\
\hline Aspectos Ambientais - 2 & $\begin{array}{l}\text { Agravamento das mudanças } \\
\text { climáticas }\end{array}$ & & & & \\
\hline Usinas - 3 & $\begin{array}{l}\text { Concorrência pelo bagaço entre } \\
\text { etanol de segunda geração e a } \\
\text { bioeletrecidade }\end{array}$ & & & & \\
\hline $\begin{array}{l}\text { Órgãos de Fomento à } \\
\text { Pesquisa - } 2\end{array}$ & $\begin{array}{l}\text { Mudanças genéticas } \\
\text { fisiológicas na cana para pré- } \\
\text { hidrólisar o bagaço na fase } \\
\text { agrícola }\end{array}$ & & & & \\
\hline
\end{tabular}

\begin{tabular}{|c|c|c|c|c|c|}
\hline Variável analisada & $\begin{array}{l}\text { Aspectos Econômicos - } 7 \\
\text { Tendência de fusões e } \\
\text { aquisições no setor }\end{array}$ & & & & \\
\hline & & Infl. & Dep. & Tipo & Grau \\
\hline Força & Descrição & $\begin{array}{l}\text { Pos. ou } \\
\text { Neg. }\end{array}$ & $\mathrm{S}$ ou $\mathrm{N}$ & Ca. ou Ef. & $\begin{array}{l}\text { B, M } \\
\text { ou A }\end{array}$ \\
\hline Aspectos Políticos - 2 & $\begin{array}{l}\text { Criação de subsídios para } \\
\text { consolidação do etanol de } \\
\text { segunda geração }\end{array}$ & & & & \\
\hline Aspectos Ambientais - 2 & $\begin{array}{l}\text { Agravamento das mudanças } \\
\text { climáticas }\end{array}$ & & & & \\
\hline Usinas - 3 & $\begin{array}{l}\text { Concorrência pelo bagaço entre } \\
\text { etanol de segunda geração e a } \\
\text { bioeletrecidade }\end{array}$ & & & & \\
\hline $\begin{array}{l}\text { Órgãos de Fomento à } \\
\text { Pesquisa - } 2\end{array}$ & $\begin{array}{l}\text { Mudanças genéticas } \\
\text { fisiológicas na cana para pré- } \\
\text { hidrólisar o bagaço na fase } \\
\text { agrícola }\end{array}$ & & & & \\
\hline
\end{tabular}

\begin{tabular}{|c|c|c|c|c|c|}
\hline \multirow[t]{2}{*}{ Variável analisada } & \multirow[t]{2}{*}{$\begin{array}{c}\text { Aspectos Políticos - } 2 \text { Criação } \\
\text { de subsídios para } \\
\text { consolidação do etanol de } \\
\text { segunda geração } \\
\end{array}$} & & & & \\
\hline & & Infl. & Dep. & Tipo & Grau \\
\hline Força & Descrição & $\begin{array}{l}\text { Pos. ou } \\
\text { Neg. }\end{array}$ & S ou N & Ca. ou Ef. & $\begin{array}{l}\mathrm{B}, \mathrm{M} \\
\text { ou A }\end{array}$ \\
\hline Aspectos Ambientais - 2 & $\begin{array}{l}\text { Agravamento das mudanças } \\
\text { climáticas }\end{array}$ & & & & \\
\hline Usinas - 3 & $\begin{array}{l}\text { Concorrência pelo bagaço entre } \\
\text { etanol de segunda geração e a } \\
\text { bioeletrecidade }\end{array}$ & & & & \\
\hline $\begin{array}{l}\text { Órgãos de Fomento à } \\
\text { Pesquisa - } 2\end{array}$ & $\begin{array}{l}\text { Mudanças } \quad \text { genéticas } \\
\text { fisiológicas na cana para pré- } \\
\text { hidrólisar o bagaço na fase } \\
\text { agrícola }\end{array}$ & & & & \\
\hline
\end{tabular}




\begin{tabular}{|l|l|c|c|c|c|}
\hline \multicolumn{1}{|c|}{ Variável analisada } & $\begin{array}{l}\text { Aspectos Ambientais - 2 } \\
\text { Agravamento das mudanças } \\
\text { climáticas }\end{array}$ & \multicolumn{1}{c|}{ Tipo } & Grau \\
\hline \multicolumn{1}{|c|}{ Força } & \multicolumn{1}{|c|}{ Descrição } & $\begin{array}{c}\text { Pos. ou } \\
\text { Neg. }\end{array}$ & S ou N & Ca. ou Ef. & $\begin{array}{c}\text { B, M } \\
\text { ou A }\end{array}$ \\
\hline Usinas - 3 & $\begin{array}{l}\text { Concorrência pelo bagaço entre } \\
\text { etanol de segunda geração e a } \\
\text { bioeletrecidade }\end{array}$ & & & \\
\hline $\begin{array}{l}\text { Órgãos de Fomento à } \\
\text { Pesquisa - 2 }\end{array}$ & $\begin{array}{l}\text { Mudanças genéticas e } \\
\text { fisiológicas na cana para pré- } \\
\text { hidrólisar o bagaço na fase } \\
\text { agrícola }\end{array}$ & & & \\
\end{tabular}

\begin{tabular}{|c|c|c|c|c|c|}
\hline Variável analisada & $\begin{array}{c}\text { Usinas - } 3 \text { Concorrência pelo } \\
\text { bagaço entre etanol de } \\
\text { segunda geração e a } \\
\text { bioeletrecidade }\end{array}$ & & & & \\
\hline & & Infl. & Dep. & Tipo & Grau \\
\hline Força & Descrição & $\begin{array}{l}\text { Pos. ou } \\
\text { Neg. }\end{array}$ & $\mathrm{S}$ ou $\mathrm{N}$ & Ca. ou Ef. & $\begin{array}{l}\text { B, M } \\
\text { ou A }\end{array}$ \\
\hline $\begin{array}{l}\text { Órgãos de Fomento à } \\
\text { Pesquisa - } 2\end{array}$ & $\begin{array}{l}\text { Mudanças genéticas } \\
\text { fisiológicas na cana para pré- } \\
\text { hidrólisar o bagaço na fase } \\
\text { agrícola }\end{array}$ & & & & \\
\hline
\end{tabular}


ANEXO 4 - Unificação de vocabulário, eliminação de variáveis supérfluas e de variáveis equivalentes.

Durante a primeira etapa do processo de identificação das variáveis ambientais, algumas dessas variáveis possuíam significado sobreposto ou ainda, mostraram-se periféricas em relação ao problema de pesquisa. Nesse sentido se realizou um tratamento semântico das variáveis a fim de que se pudesse consolidar a lista de variáveis em seus aspectos mais relevantes e se chegasse a um número de variáveis que fosse operacionalmente favorável para a segunda fase das entrevistas. Segue abaixo a tabela de cada Stakeholder com as variáveis brutas, a descrição do processo de tratamento das variáveis e a tabela dessas variáveis já tratadas.

a) Stakeholder: Centro de tecnologia

Tabela de variáveis ambientais brutas:

\begin{tabular}{|l|r|}
\hline Descrição & Variável \\
\hline Força o desenvolvimento de microorganismos produtores de enzimas & 1 \\
\hline Força o desenvolvimento de coquetéis enzimáticos mais eficientes & 2 \\
\hline Força o desenvolvimento de métodos mais eficientes de tratamento do bagaço & 3 \\
\hline Força a integração da pesquisa pública com a pesquisa privada & 4 \\
\hline Força a fermentação de pentoses & 5 \\
\hline Força a elaboração de simuladores de usinas de etanol de segunda geração & 6 \\
\hline
\end{tabular}

Comentários: Das seis variáveis originais foram alteradas duas variáveis. Unificou-se a variável "Força a integração da pesquisa pública com a pesquisa privada" (centro de tecnologia - 4) com a variável "Alinha estratégias de pesquisa segundo necessidades da indústria" (entidade de classe - 2). A variável "Força a fermentação de pentoses” (centro de tecnologia - 5) foi eliminada visto que esse desafio técnico está contido na variável "Financia a pesquisa nos gargalos técnicos para consolidação do etanol de segunda geração" '(órgão de fomento - 1). A configuração final das variáveis do stakeholder “centro de tecnologia” apresenta-se abaixo: 
Tabela de variáveis ambientais tratadas:

\begin{tabular}{|l|r|}
\hline Descrição & Variável \\
\hline Força o desenvolvimento de microorganismos mais eficientes & 1 \\
\hline Força o desenvolvimento de coquetéis enzimáticos mais eficientes & 2 \\
\hline Força o desenvolvimento de métodos mais eficientes de tratamento do bagaço & 3 \\
\hline Força a elaboração de simuladores de usinas de etanol de segunda geração & 4 \\
\hline
\end{tabular}

b) Stakeholder: Universidade

Tabela de variáveis ambientais brutas:

\begin{tabular}{|l|l|}
\hline Universidades & \\
\hline Força a criação de centros de pesquisa & 1 \\
\hline Força a integração da pesquisa nacional com a pesquisa internacional & 2 \\
\hline Força a formação de recursos humanos & 3 \\
\hline
\end{tabular}

Comentários: Das três variáveis identificadas inicialmente, a variável "Força a integração da pesquisa nacional com a pesquisa internacional” (universidade - 2) foi suprimida em virtude da variável "Pesquisa brasileira em biocombustíveis é internacionalizada e possuidora de classe mundial” (macroambiente tecnológico -5 ) já indicar alto grau de internacionalização.

Tabela de variáveis ambientais tratadas:

\begin{tabular}{|l|l|}
\hline Universidades & \\
\hline Força a criação de centros de pesquisa & 1 \\
\hline Força a formação de recursos humanos & 2 \\
\hline
\end{tabular}

c) Stakeholder: Órgão de fomento à pesquisa

Tabela de variáveis ambientais brutas:

\begin{tabular}{|l|l|}
\hline Órgão de fomento de pesquisa & \\
\hline Financia a pesquisa nos gargalos técnicos para consolidação do etanol de segunda geração & 1 \\
\hline Financia engenharia fisiológica para inibição de fenóis lignocelulósicos & 2 \\
\hline Descoberta de novas rotas para produção do etanol celulósico & 3 \\
\hline Mudanças genéticas e fisiológicas na cana para pré-hidrólisar o bagaço na fase agrícola & 4 \\
\hline
\end{tabular}

Comentários: Das quatro variáveis originalmente identificadas as variáveis: "Financia engenharia fisiológica para inibição de fenóis lignocelulósicos” (órgão de fomento - 
2) e "Descoberta de novas rotas para produção do etanol celulósico” (órgão de fomento - 3) foram suprimidas em virtude de estarem contidas na variável "Financia a pesquisa nos gargalos técnicos para consolidação do etanol de segunda geração” (órgão de fomento - 1).

Tabela de variáveis ambientais tratadas:

Órgão de fomento de pesquisa

Financia a pesquisa nos gargalos técnicos para consolidação do etanol de segunda geração

Mudanças genéticas e fisiológicas na cana para pré-hidrólisar o bagaço na fase agrícola

1

d) Stakeholder: Fabricante de insumos

Tabela de variáveis ambientais brutas:

Fabricante de insumos

Força diminuição do custo de produção das enzimas

Força aumento da escala na utilização das enzimas

2

Comentários: As duas variáveis "Força diminuição do custo de produção das enzimas" (fabricante de insumos - 1) e "Força aumento da escala na utilização das enzimas” (fabricante de insumos - 2), estão ligadas devido à relação lógica que existe entre o custo de produção e o aumento na escala produtiva. Sendo assim, unificaram-sese as duas variáveis em uma só variável que contivesse os dois aspectos.

Tabela de variáveis ambientais tratadas:

Fabricante de insumos

Força diminuição do custo de produção das enzimas através do aumento da escala produtiva 1

e) Stakeholder: Entidade de classe da indústria da cana

Tabela de variáveis ambientais brutas:

Entidade de classe da indústria da cana

Força abertura de mercados nacionais e internacionais para o etanol brasileiro

Alinha estratégias de pesquisa segundo necessidades da indústria 
Comentários: Não houve retificação nas variáveis desse stakeholder.

f) Stakeholder: Usina de etanol

Tabela de variáveis ambientais brutas:

\begin{tabular}{|l|l|}
\hline Usina de etanol & 1 \\
\hline Força a mecanização agrícola & 2 \\
\hline Força a integração da tecnologia de 1.a geração com a tecnologia de 2.a geração & 3 \\
\hline Concorrência pelo bagaço entre etanol de segunda geração e a bioeletrecidade & 4 \\
\hline Eletrificação e automação do sistema de produção atual & \\
\hline
\end{tabular}

Comentários: Não houve retificação nas variáveis desse stakeholder.

g) Stakeholder: Empresa pública do setor sucroenergético

Tabela de variáveis ambientais brutas:

Empresa pública do setor sucroenergético

Força o desenvolvimento de equipamentos para fase agrícola

Comentários: Não houve retificação nas variáveis desse stakeholder.

h) Stakeholder: Governo

Tabela de variáveis brutas:

\begin{tabular}{|l|l|}
\hline Governo & \\
\hline Força a construção de plantas de etanol de segunda geração em escala pré-industrial & 1 \\
\hline Força a adoção internacional da mistura de etanol à gasolina & 2 \\
\hline Força o investimento em termo-elétricas à etanol & 3 \\
\hline Força equilíbrio entre oferta e demanda de etanol no mercado interno de etanol & 4 \\
\hline Força a construção de alcooldutos e a utilização da infra-estrutura petroquímica & 5 \\
\hline
\end{tabular}

Comentários: A variável "Força o investimento em termo-elétricas à etanol" (governo -3) foi suprimida devido à inviabilidade econômica de se queimar etanol para gerar eletricidade visto que já se queima o bagaço e a palha para esse fim. A variável

"Força a adoção internacional da mistura de etanol à gasolina” (governo - 2) foi 
suprimida por estar contida na variável "Força abertura de mercados nacionais e internacionais para o etanol brasileiro” (entidade de classe da indústria da cana - 1).

Tabela de variáveis ambientais tratadas:

\begin{tabular}{|l|l|}
\hline Governo & \\
\hline Força a construção de plantas de etanol de segunda geração em escala pré-industrial & 1 \\
\hline Força equilíbrio entre oferta e demanda de etanol no mercado interno & 2 \\
\hline Força a construção de alcooldutos e a utilização da infra-estrutura petroquímica & 3 \\
\hline
\end{tabular}

i) Stakeholder: Fabricante de equipamentos

Tabela de variáveis ambientais brutas:

\begin{tabular}{|l|l|}
\hline Fabricante de equipamentos & \\
\hline Fornece equipamentos para pré-tratamento do bagaço & 1 \\
\hline Força o desenvolvimento de biorreatores para produção em larga escala & 2 \\
\hline Fornece equipamentos para produção enzimática & 3 \\
\hline
\end{tabular}

Comentários: As variáveis "Fornece equipamentos para pré-tratamento do bagaço" (fabricante de equipamentos - 1) e “Fornece equipamentos para produção enzimática” (fabricante de equipamentos - 3) foram unificadas em uma variável denominada: “Desenvolve e fornece equipamentos para tratamento do bagaço e produção de enzimas” (fabricante de equipamentos - 1).

Tabela de variáveis ambientais tratadas:

Fabricante de equipamentos

Desenvolve e fornece equipamentos para tratamento do bagaço e produção de enzimas

Força o desenvolvimento de biorreatores para produção em larga escala 1

j) Stakeholder: Imprensa especializada

Tabela de variáveis ambientais brutas: 
Imprensa especializada

Força a divulgação da existência de novas tecnologias para a indústria

Gera a opinião pública sobre o etanol de segunda geração

Publica artigos gerados na indústria

Comentários: A variável "Força a divulgação da existência de novas tecnologias para a indústria” (imprensa especializada - 1) foi suprimida pelo fato da variável “Fonte de informação para aquisição de tecnologia” (órgãos de patente - 2) cumprir esse papel. As variáveis "Gera a opinião pública sobre o etanol de segunda geração” (imprensa especializada - 2) e "Publica artigos gerados na indústria" (imprensa especializada -3) foram fundidas na variável: “Forma a opinião pública favorável ou desfavorável sobre o etanol de segunda geração” (imprensa especializada - 1).

Tabela de variáveis ambientais tratadas:

Imprensa especializada

Forma a opinião pública favorável ou desfavorável sobre o etanol de segunda geração 1

l) Stakeholder: Empresa de consultoria financeira, empresa de consultoria de engenharia e centro de pesquisas econômicas.

Tabela de variáveis ambientais brutas:

\begin{tabular}{|l|c|}
\hline Empresa de consultoria em financiamento & \\
\hline Facilita o desenvolvimento econômico do setor & 1 \\
\hline Empresa de consultoria em Engenharia & \\
\hline Facilita o desenvolvimento técnico do setor & 1 \\
\hline Centro de pesquisas econômicas & \\
\hline Gera de índices sobre o setor de bioenergia & 1 \\
\hline
\end{tabular}

Comentário: Os três stakeholders mostraram-se como importantes facilitadores do desenvolvimento do setor, possuindo características comuns e trabalhando em conjunto para servir a indústria. Nesse sentido unificaram-se os stakeholders em uma classe única visto que as três variáveis geradas puderam ser tratadas como uma só variável. As variáveis "Facilita o investimento na produção de segunda geração" (empresa de consultoria e financiamento - 1), "Facilita projetos de etanol de segunda geração" 
(empresa de consultoria em engenharia - 1) e “Gera índices sobre o setor de bioenergia” (centro de pesquisas econômicas - 1), deram origem à variável "Facilita o desenvolvimento técnico e econômico do setor" (empresas de consultoria financeira e técnica - 1).

Tabela de variáveis ambientais tratadas:

Empresas de consultoria financeira e técnica

Facilita o desenvolvimento técnico e econômico do setor 1

m) Stakeholder: Instituições financeiras

Tabela de variáveis ambientais brutas:

\begin{tabular}{|l|l|}
\hline Instituição financeira & \\
\hline Financia a aquisição de tecnologia por parte do setor & 1 \\
\hline Financia o crescimento geral do setor & 2 \\
\hline Financia o capital de giro & 3 \\
\hline
\end{tabular}

Comentários: As variáveis "Financia a aquisição de tecnologia por parte do setor" (instituição financeira - 1), "Financia o crescimento geral do setor" (instituição financeira - 2) e "Financia o capital de giro" (instituição financeira - 3), foram unificadas na variável "Facilita o desenvolvimento técnico e econômico do setor" (Empresas de consultoria financeira e técnica - 1).

Instituição financeira

Financia a consolidação técnica e econômica do setor

n) Stakeholder: Órgãos de patentes

Tabela de variáveis ambientais brutas:

\begin{tabular}{|l|l|}
\hline Órgãos de Patentes & \\
\hline Garante direito sobre inovação tecnológica & 1 \\
\hline Fonte de informação para aquisição de tecnologia & 2 \\
\hline
\end{tabular}

Comentários: Não houve retificação nas variáveis desse stakeholder. 
o) Stakeholder: Montadoras

Tabela de variáveis ambientais brutas:

\begin{tabular}{|l|l|}
\hline Montadoras & \\
\hline Força o desenvolvimento de motores pesados movidos à etanol & 1 \\
\hline Força a internacionalização da tecnologia Flex-fuel & 2 \\
\hline Força a disseminação do carro elétrico & 3 \\
\hline Força o desenvolvimento de motocicletas movidas à etanol & 4 \\
\hline
\end{tabular}

Comentários: A variável "Força o desenvolvimento de motores pesados movidos à etanol" (montadoras - 1) e "Força o desenvolvimento de motocicletas movidas à etanol” (montadoras - 4) foram unificadas na variável “Força o desenvolvimento de motores leves e pesados movidos à etanol” (montadoras - 1).

Tabela de variáveis ambientais tratadas:

\begin{tabular}{|l|l|}
\hline Montadoras & \\
\hline Força o desenvolvimento de motores leves e pesados movidos à etanol & 1 \\
\hline Força a internacionalização da tecnologia Flex-fuel & 2 \\
\hline Força a disseminação do carro elétrico & 3 \\
\hline
\end{tabular}

p) Stakeholder: Empresa privada de pesquisa tecnológica

Tabela de variáveis ambientais brutas:

\begin{tabular}{|l|l|}
\hline Empresa privada de pesquisa tecnológica & \\
\hline Força o desenvolvimento de cana transgênica com mais sacarose & 1 \\
\hline Força o desenvolvimento de cana transgênica mais resistente & 2 \\
\hline Força o desenvolvimento de cana transgênica com mais celulose & 3 \\
\hline
\end{tabular}

Comentários: As variáveis "Força o desenvolvimento de cana transgênica com mais sacarose” (empresa privada de pesquisa tecnológica - 1), “Força o desenvolvimento de cana transgênica mais resistente” (empresa privada de pesquisa tecnológica - 2), “Força o desenvolvimento de cana transgênica com mais celulose” (empresa privada 
de pesquisa tecnológica - 3) foram unificadas na variável "Força o desenvolvimento de cana transgênica para aumentar produção na fase agrícola” (empresa privada de pesquisa tecnológica - 1).

Tabela de variáveis ambientais tratadas:

Empresa privada de pesquisa tecnológica

Força o desenvolvimento de cana transgênica para aumentar produção na fase agrícola

\section{Macroambiente}

q) Aspectos tecnológicos

Tabela de variáveis ambientais brutas:

\begin{tabular}{|l|l|}
\hline a) Aspectos tecnológicos & \\
\hline Produção de plástico biodegradável a partir do etanol & 1 \\
\hline Surgimento de novos tipos de biorreatores para ampliação de escala produtiva & 2 \\
\hline Produção simultânea de etanol de segunda geração, açúcar, bioeletrecidade e derivados & 3 \\
\hline Viabilidade de hidrolizar resíduos agrícolas & 4 \\
\hline Possibilidade de uso da infra-estrutura petroquímica para transporte de etanol & 5 \\
\hline Desenvolvimento de turbinas movidas à etanol para indústria aero-espacial & 6 \\
\hline Aproveitamento do bagaço pós-hidrólise para fabricação de ração animal & 7 \\
\hline Produzir metano a partir do vinhoto & 8 \\
\hline Produzir bio-fertilizante a partir do vinhoto & 9 \\
\hline Pesquisa brasileira em biocombustíveis é internacionalizada e possuidora de classe mundial & 10 \\
\hline
\end{tabular}

Comentários: A variável "Surgimento de novos tipos de biorreatores para ampliação de escala produtiva” (aspectos tecnológicos - 2) foi suprimida por estar contida na variável "Força o desenvolvimento de biorreatores para produção em larga escala" (fabricante de equipamentos - 2). A variável "Possibilidade de uso da infra-estrutura petroquímica para transporte de etanol” (aspectos tecnológicos - 5) foi suprimida por estar contida na variável "Força a construção de alcooldutos e a utilização da infra-estrutura petroquímica” (governo - 3). A variável “Desenvolvimento de turbinas movidas à etanol para indústria aero-espacial” (aspectos tecnológicos - 6) foi suprimida por ser marginal ao problema pesquisado (mercado muito restrito) e estar num horizonte de tempo que foge ao escopo de análise dos cenários propostos. As variáveis "Produzir metano a partir do vinhoto" 
(aspectos tecnológicos - 8) e "Produzir bio-fertilizante a partir do vinhoto" (aspectos tecnológicos - 9) foram suprimidas por estarem contidas na variável “Produção simultânea de etanol de segunda geração, açúcar, bioeletrecidade e derivados” (aspectos tecnológicos - 3).

Tabela de variáveis ambientais tratadas:

\begin{tabular}{|l|l|}
\hline Aspectos tecnológicos & \\
\hline Produção de plástico biodegradável a partir do etanol & 1 \\
\hline Produção simultânea de etanol de segunda geração, açúcar, bioeletrecidade e derivados & 2 \\
\hline Viabilidade de hidrolizar resíduos agrícolas & 3 \\
\hline Aproveitamento do bagaço pós-hidrólise para fabricação de ração animal & 4 \\
\hline Pesquisa brasileira em biocombustíveis é internacionalizada e possuidora de classe mundial & 5 \\
\hline
\end{tabular}

r) Macroambiente Social

Tabela de variáveis ambientais brutas:

\begin{tabular}{|l|l|}
\hline Aspectos sociais & \\
\hline Adequação do setor às normas trabalhistas & 1 \\
\hline Término da queima e da colheita manual da cana & 2 \\
\hline Competição com alimentos por uso da terra & 4 \\
\hline Recolocação motivada pela mecanização do campo & 5 \\
\hline Aumento da escolaridade da mão de obra no campo & 6 \\
\hline
\end{tabular}

A variável “Aumento da escolaridade da mão de obra no campo” (aspectos sociais 6) foi suprimida por estar contida no processo de treinamento e educação necessário para a recolocação do trabalhador rural descrito na variável "Recolocação motivada pela mecanização do campo" (aspectos sociais - 5).

Tabelas de variáveis ambientais tratadas:

\begin{tabular}{|l|l|}
\hline Aspectos sociais & 1 \\
\hline Adequação do setor às normas trabalhistas & 2 \\
\hline Término da queima e da colheita manual da cana & 3 \\
\hline Recolocação motivada pela mecanização do campo & 4 \\
\hline Competição com alimentos por uso da terra & 4 \\
\hline
\end{tabular}

s) Aspectos econômicos

Tabela de variáveis ambientais brutas: 


\begin{tabular}{|l|l|}
\hline Aspectos econômicos & \\
\hline Preço do açúcar & 1 \\
\hline Preço do petróleo & 2 \\
\hline Valor relativo das moedas estrangeiras & 3 \\
\hline Aumento da escala de produção do etanol de segunda geração & 4 \\
\hline Descoberta de jazidas de petróleo & 5 \\
\hline Logística brasileira favorável para uso da biomassa (bagaço) & 6 \\
\hline Alto investimento dos EUA em 2.a geração & 7 \\
\hline Baixo preço da energia elétrica & 8 \\
\hline Tendência de fusões e aquisições no setor & 9 \\
\hline Força menores taxas de juros para financiamento de tecnologia de segunda geração & 10 \\
\hline Preço do etanol & 11 \\
\hline Alta produtividade de biomassa no Brasil & 12 \\
\hline Abundância de terras para produzir biomassa no Brasil & 13 \\
\hline
\end{tabular}

Comentários: A variável “Aumento da escala de produção do etanol de segunda geração" (aspectos econômicos - 3) foi suprimida por estar contida na variável "Força a construção de plantas de etanol de segunda geração em escala pré-industrial” (governo - 1). A variável “Alto investimento dos EUA em 2.a geração” (aspectos econômicos - 7) foi suprimida por se tornar periférica quando se considera a variável “Pesquisa brasileira em biocombustíveis é internacionalizada e possuidora de classe mundial” (aspectos tecnológicos - 5). As variáveis “Alta produtividade de biomassa no Brasil” (aspectos econômicos - 12) e “Abundância de terras para produzir biomassa no Brasil” (aspectos econômicos - 13) foram unificadas na variável “Alto potencial produtivo de biomassa no Brasil” (aspectos econômicos 10).

Tabela de variáveis ambientais tratadas:

\begin{tabular}{|l|l|}
\hline Aspectos econômicos & \\
\hline Preço do açúcar & 1 \\
\hline Preço do petróleo & 2 \\
\hline Valor relativo das moedas estrangeiras & 3 \\
\hline Descoberta de jazidas de petróleo & 4 \\
\hline Logística brasileira favorável para uso da biomassa (bagaço) & 5 \\
\hline Baixo preço da energia elétrica & 6 \\
\hline Tendência de fusões e aquisições no setor & 7 \\
\hline Força menores taxas de juros para financiamento de tecnologia de segunda geração & 8 \\
\hline Preço do etanol & 9 \\
\hline Alto potencial produtivo de biomassa no Brasil & 10 \\
\hline
\end{tabular}

\section{t) Aspectos Políticos}


Tabela de variáveis ambientais brutas:

\begin{tabular}{|l|l|}
\hline Aspectos políticos & \\
\hline Comoditização do etanol & 1 \\
\hline Criação de subsídios e incentivos fiscais para consolidação do etanol de segunda geração & 2 \\
\hline Ausência de tarifas alfandegárias nos EUA para o açúcar produzido no nordeste brasileiro & 3 \\
\hline Aspecto estratégico na diversificação da matriz energética & 4 \\
\hline Protecionismo estrangeiro & 5 \\
\hline
\end{tabular}

Comentários: Não houve retificação nas variáveis.

u) Aspectos Ambientais

Tabela de variáveis ambientais brutas:

\begin{tabular}{|l|l|}
\hline f) Aspectos Ambientais & \\
\hline Diminuição do impacto ambiental promovido pelo etanol de segunda geração & 1 \\
\hline Agravamento das mudanças climáticas & 2 \\
\hline Uso sustentável da água & 3 \\
\hline Biossegurança de OGMs & 4 \\
\hline Fixação de metas internacionais de emissões de CO2 & 5 \\
\hline Adesão ao zonamento agroambiental & 6 \\
\hline
\end{tabular}

Comentários: Não houve retificação nas variáveis. 